University of Tennessee Health Science Center UTHSC Digital Commons

\title{
$5-2019$
}

\section{Injectable Systems for Long-Lasting Insulin Therapy}

\author{
Kumar Kulldeep Niloy \\ University of Tennessee Health Science Center
}

Follow this and additional works at: https://dc.uthsc.edu/dissertations

Part of the Pharmacy and Pharmaceutical Sciences Commons

\section{Recommended Citation}

Niloy, Kumar Kulldeep (0000-0001-9307-7899), "Injectable Systems for Long-Lasting Insulin Therapy" (2019). Theses and Dissertations (ETD). Paper 487. http://dx.doi.org/10.21007/etd.cghs.2019.0479.

This Thesis is brought to you for free and open access by the College of Graduate Health Sciences at UTHSC Digital Commons. It has been accepted for inclusion in Theses and Dissertations (ETD) by an authorized administrator of UTHSC Digital Commons. For more information, please contact jwelch30@uthsc.edu. 


\title{
Injectable Systems for Long-Lasting Insulin Therapy
}

\begin{abstract}
Diabetes mellitus is one of the major global health problems and the prevalence rate is ever increasing reaching to $48 \%$ increase by the year of 2040 causing significant economic burdens. Insulin therapy has been the mainstay of diabetes treatment since its discovery in 1922. However, insulin is an unstable peptide with a half-life of only 4-6 min which poses significant challenge in prolonging duration of action of insulin. Nevertheless, the advances in recombinant DNA technology and protein engineering have enabled the development of several long-acting insulin analogue products which show duration of action up to $42 \mathrm{~h}$. However, these insulin analogues still require once- or twice-daily injections for optimal glycemic control resulting in poor compliance and adherence issues among patients. To achieve insulin release for more than one day, different injectable delivery systems including microspheres, in situ forming depots, nanoparticles and composite systems have been developed for sustained release of insulin for days to weeks in in vitro and preclinical studies. Several of these delivery systems have further advanced to clinical trials for once-weekly insulin injection to treat diabetes. Although a number of review articles have appeared in the literature to discuss the developments of long-acting insulin analogues and sustained release insulin delivery systems, none of them comprehensively cover the whole area starting all the way from prototype design and preclinical studies to clinical trials and marketed products. The scope of this review is to fill in the gap and comprehensively summarize the developments of injectable insulin analogues and delivery systems for long-term glycemic control and improved patient compliance.
\end{abstract}

\section{Document Type}

Thesis

Degree Name

Master of Science (MS)

Program

Pharmaceutical Sciences

Research Advisor

Tao L. Lowe, Ph.D.

Keywords

Diabetes, Injectables, Insulin, Sustained Release

Subject Categories

Medicine and Health Sciences | Pharmacy and Pharmaceutical Sciences 


\title{
Injectable Systems for Long-Lasting Insulin Therapy
}

\author{
A Thesis \\ Presented for \\ The Graduate Studies Council \\ The University of Tennessee \\ Health Science Center
}

\author{
In Partial Fulfillment \\ Of the Requirements for the Degree \\ Master of Science \\ From The University of Tennessee
}

By

Kumar Kulldeep Niloy

May 2019 
Copyright (C) 2019 by Kumar Kulldeep Niloy. All rights reserved. 


\section{ACKNOWLEDGEMENTS}

I would like to express my deepest gratitude to Dr. Tao L. Lowe for her incredible mentorship throughout this journey. I am thankful to Dr. Isaac O. Donkor and Dr. David J. Hamilton to serve in my committee.

I am grateful to our previous and current lab members Dr. Muhammad Gulfam, Dr. Fitsum F. Sahle, Sangyoon Kim, Darren S. Will, Chandana Damera, Faiza Tahia, Emily M. Cooper and Cameron V. Fili for their unconditional support.

I am indebted to my parents, Mr. Nirmal Chandra Kuri and Mrs. Rita Rani Kuri, my wife, Hridita Roy and other family members for their endless patience, care, encouragement, love and support. 


\begin{abstract}
Diabetes mellitus is one of the major global health problems and the prevalence rate is ever increasing reaching to $48 \%$ increase by the year of 2040 causing significant economic burdens. Insulin therapy has been the mainstay of diabetes treatment since its discovery in 1922. However, insulin is an unstable peptide with a half-life of only 4-6 min which poses significant challenge in prolonging duration of action of insulin. Nevertheless, the advances in recombinant DNA technology and protein engineering have enabled the development of several long-acting insulin analogue products which show duration of action up to $42 \mathrm{~h}$. However, these insulin analogues still require onceor twice-daily injections for optimal glycemic control resulting in poor compliance and adherence issues among patients. To achieve insulin release for more than one day, different injectable delivery systems including microspheres, in situ forming depots, nanoparticles and composite systems have been developed for sustained release of insulin for days to weeks in in vitro and preclinical studies. Several of these delivery systems have further advanced to clinical trials for once-weekly insulin injection to treat diabetes. Although a number of review articles have appeared in the literature to discuss the developments of long-acting insulin analogues and sustained release insulin delivery systems, none of them comprehensively cover the whole area starting all the way from prototype design and preclinical studies to clinical trials and marketed products. The scope of this review is to fill in the gap and comprehensively summarize the developments of injectable insulin analogues and delivery systems for long-term glycemic control and improved patient compliance.
\end{abstract}




\section{TABLE OF CONTENTS}

CHAPTER 1. INTRODUCTION .........................................................................................1

CHAPTER 2. INJECTABLE INSULINS IN THE MARKET ......................................4

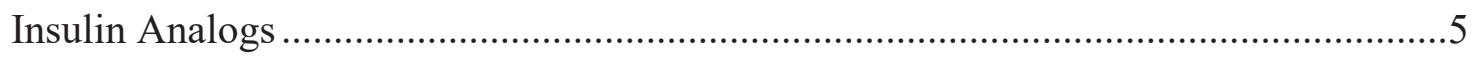

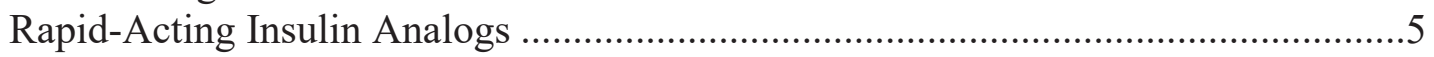

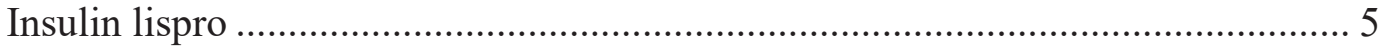

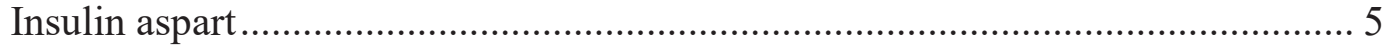

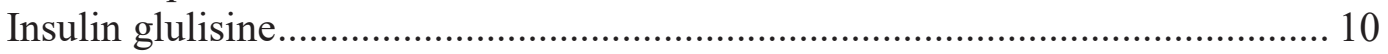

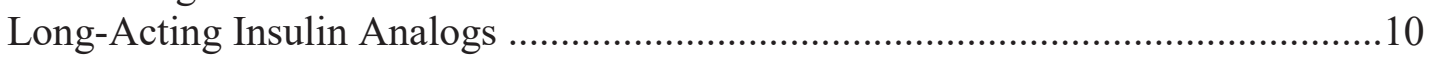

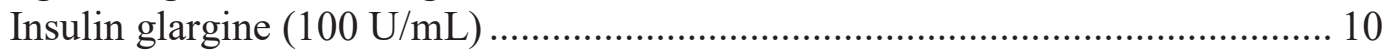

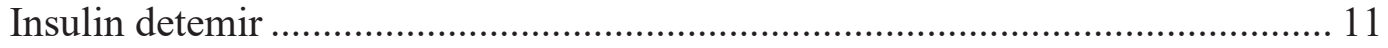

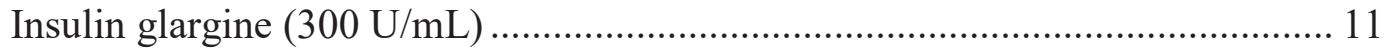

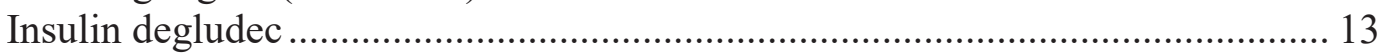

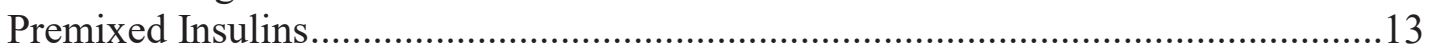

Excipients in Long-Acting Insulin Analog Formulations..........................................15

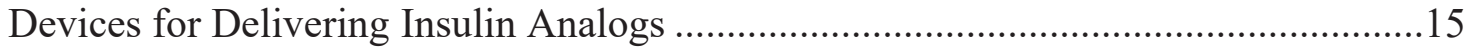

CHAPTER 3. INJECTABLE DELIVERY SYSTEMS FOR INSULIN ...................19

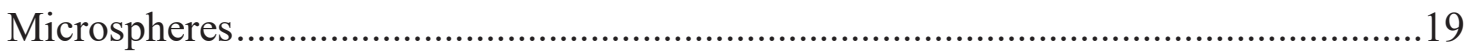

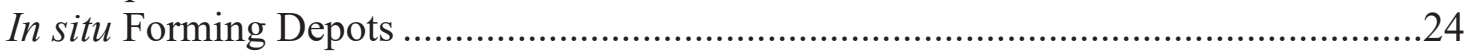

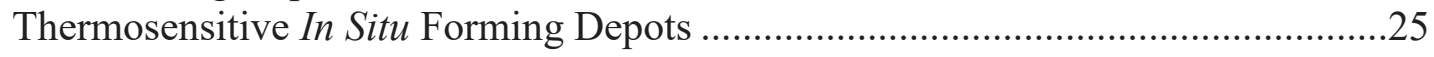

Phase Inversion Based In Situ Forming Depots...............................................28

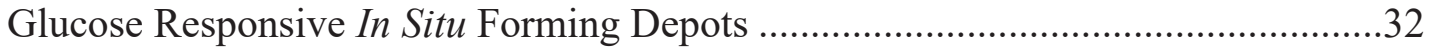

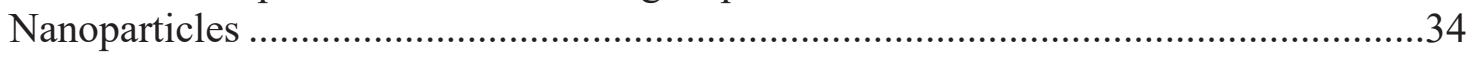

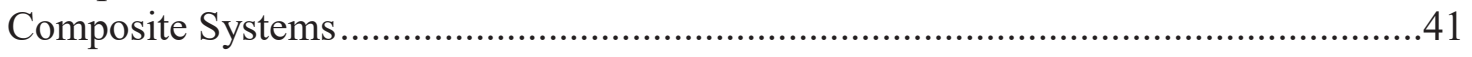

CHAPTER 4. INJECTABLE INSULINS IN CLINICAL TRIALS ........................45

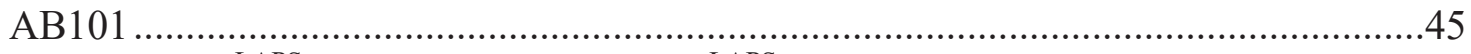

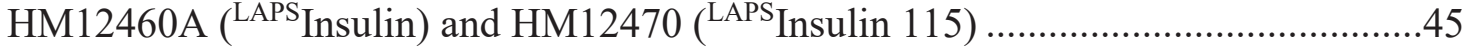

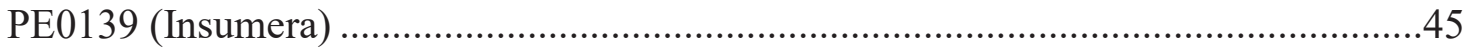

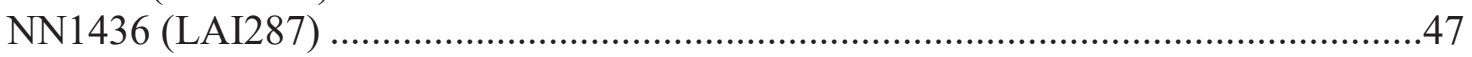

CHAPTER 5. CONCLUSION AND PERSPECTIVE ................................................48

LIST OF REFERENCES ........................................................................................................49

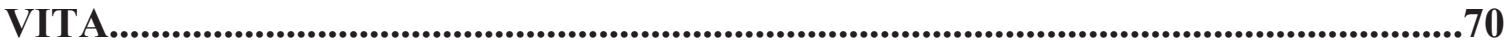




\section{LIST OF TABLES}

Table 2-1. Currently approved insulin injectables available in the US market..............6

Table 2-2. Excipients in long-acting insulin formulations .........................................16

Table 3-1. Examples of microsphere formulations used in preclinical studies for

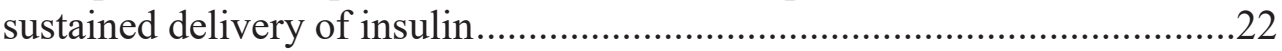

Table 4-1. Injectable sustained release systems for insulin under clinical trials ...........46 


\section{LIST OF FIGURES}

Figure 1-1. Primary structure of native human insulin .............................................2

Figure 2-1. Structural modifications of human insulin to develop insulin analogs ..........9

Figure 2-2. Protraction mechanism of insulin analogs ............................................. 12

Figure 2-3. Protraction mechanism of insulin degludec ........................................ 14

Figure 2-4. Mechanism of insulin fibrillation in monomeric form ..............................17

Figure 3-1. Summary findings and representative images of sustained release delivery systems for insulin investigated in preclinical studies ..................20

Figure 3-2. Chitosan-zinc-insulin loaded thermo-sensitive non-ionic in situ forming

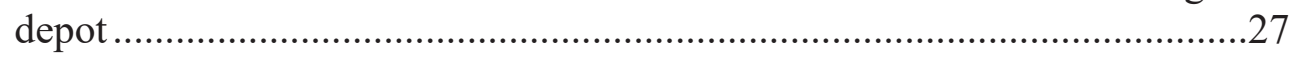

Figure 3-3. Insulin loaded thermo-sensitive cationic in situ forming depot..................29

Figure 3-4. Thermo-sensitive pentablock co-polymer based cationic in situ forming

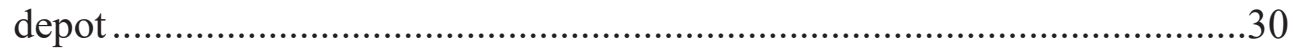

Figure 3-5. Phase inversion based in situ forming depot.......................................... 31

Figure 3-6. Comparison of blood glucose lowering effect of PLGA phase inversion based in situ forming depot with various zinc sulfate concentration in

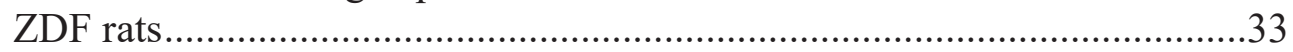

Figure 3-7. Sustained release PEG-PLGA nanoparticles ............................................36

Figure 3-8. Enzyme loaded sustained release nanoparticles ....................................38

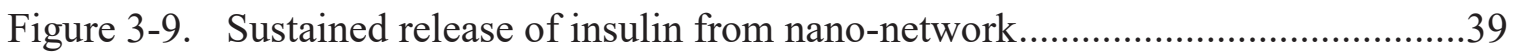

Figure 3-10. Glucose responsive enzyme coated nanoparticles ..................................40

Figure 3-11. Microsphere-gel based composite system ...........................................42

Figure 3-12. Nanoparticle-gel based composite system ..........................................44 


\section{LIST OF ABBREVIATIONS}

BA
BB
DOP
Gp
HA
HPMC
HPßCD
p(CPH/SA)
p(CPP:SA)
PAE
PAF
PBA
PCL
PEG
PEO-PPO-PEO
PHBHHx
PLA
PLGA
TEM

\author{
Benzyl alcohol \\ Benzyl benzoate \\ Dopamine \\ $\beta$-glycerol phosphate \\ Hyaluronic acid \\ Hydroxypropyl methyl cellulose \\ Hydroxypropyl- $\beta$-cyclodextrin \\ Poly 1,3-bis-(p-carboxyphenoxy) hexane-co-sebacic acid \\ 1,3-bis-(p-carboxyphenoxy) propane-co-sebacic acid \\ Poly $(\beta$-amino ester $)$ \\ Poly(alanine-co-phenyl alanine) \\ Phenylboronic acid \\ Poly( $\varepsilon$-caprolactone) \\ Poly (ethylene glycol) \\ Poly (ethylene oxide)/poly (propylene oxide)/poly (ethylene oxide) \\ Poly(3-hydroxybutyrate-co-3-hydroxyhexanoate) \\ Polylactic acid \\ Poly(lactic-co-glycolic acid) \\ Transmission electron microscopy
}




\section{CHAPTER 1. INTRODUCTION}

Diabetes mellitus, commonly known as diabetes, is an endocrine disorder characterized by persistently high blood glucose level over a prolonged period. According to CDC National Diabetes Statistics Report published in 2017, nearly 30.3 million Americans, i.e. approximately 1 out of 10 people in US, have diabetes, and among which about $5 \%$ of the patients have type 1 diabetes and $95 \%$ of the patients are estimated to have type 2 diabetes [1]. The global economic burden of diabetes was estimated \$1.3 trillion in 2015 [2]. In US, the total cost of diagnosed diabetes was estimated \$327 billion in 2017 including \$237 billion for direct medical costs and the rest for reduced productivity of the diabetic patients [2]. Type 1 diabetes is characterized by pancreatic $\beta$-cell destruction leading to absolute insulin deficiency; whereas type 2 diabetes is characterized by insulin resistance with a progressive deficiency in insulin secretion by pancreatic $\beta$-cells, and [3]. Both type 1 and type 2 diabetes manifest persistent elevation of blood glucose level including blood glucose concentration $>125$ $\mathrm{mg} / \mathrm{dL}$ and hemoglobin $\mathrm{A} 1 \mathrm{c}(\mathrm{HbA} 1 \mathrm{c})$ level, a form of hemoglobin that is covalently bound to glucose, $>6.5 \%$ [4]. HbA1c is considered as a well-established surrogate for long-term glycemic control and therefore, reductions in $\mathrm{HbAlc}$ reflects long-term glycemic control. However, if untreated, both type of diabetes can cause serious complications including stroke, myocardial infarction, vision loss, amputation, chronic kidney diseases and mortality [5-7]. For patients with type 1 diabetes, multiple daily injections of insulin are the only treatment option. For patients with type 2 diabetes, the treatment starts with management of diabetes through change in life style including healthy eating, weight loss and regular exercise followed by pharmacological intervention with oral metformin monotherapy. If normoglycemia is still not achieved, metformin is given in combination with the following small molecule oral medications: sulfonylurea, thiazolidinedione, DPP-4 inhibitor and SGLT2 inhibitor [8]. However, these oral medications often fail to achieve desired glucose lowering effect, and insulin therapy is eventually included in the treatment regimen when the hemoglobin Alc (HbAlc) level of type 2 diabetic patients is more than 6.5\% [9]. Given the prevalence of type 2 diabetes, type 2 diabetic patients account for the use of majority of insulin in the market.

Insulin is an anabolic hormone with a short half-life of 4-6 min and it is secreted from pancreatic beta cells. It regulates the blood glucose level in the body by facilitating the absorption of glucose by different tissues such as liver, fat and muscle tissues. One monomer of regular human insulin consists of an A chain and a B chain linked by two disulfide bridges between two chains and one disulfide bond between two amino acids in A chain. Two monomers form a dimer due to hydrogen bonding and hydrophobic interactions $[10,11]$ and B chain residues B8, B9, B12, B16, B21 and B23-28 participate in monomer-monomer interaction to form dimer (Figure 1-1) [12, 13]. Three dimers form a hexamer in the presence of zinc where histidine residue at $\mathrm{B} 10$ position of each monomer co-ordinates with zinc ion and A13, A14, A17, B1, B2, B4, B13, B14 and B1719 residues participate in dimer-dimer interaction (Figure 1-1) [12, 13]. Insulin remains as hexamer in glucose regulated secretory vesicles of pancreatic beta cells. High blood 


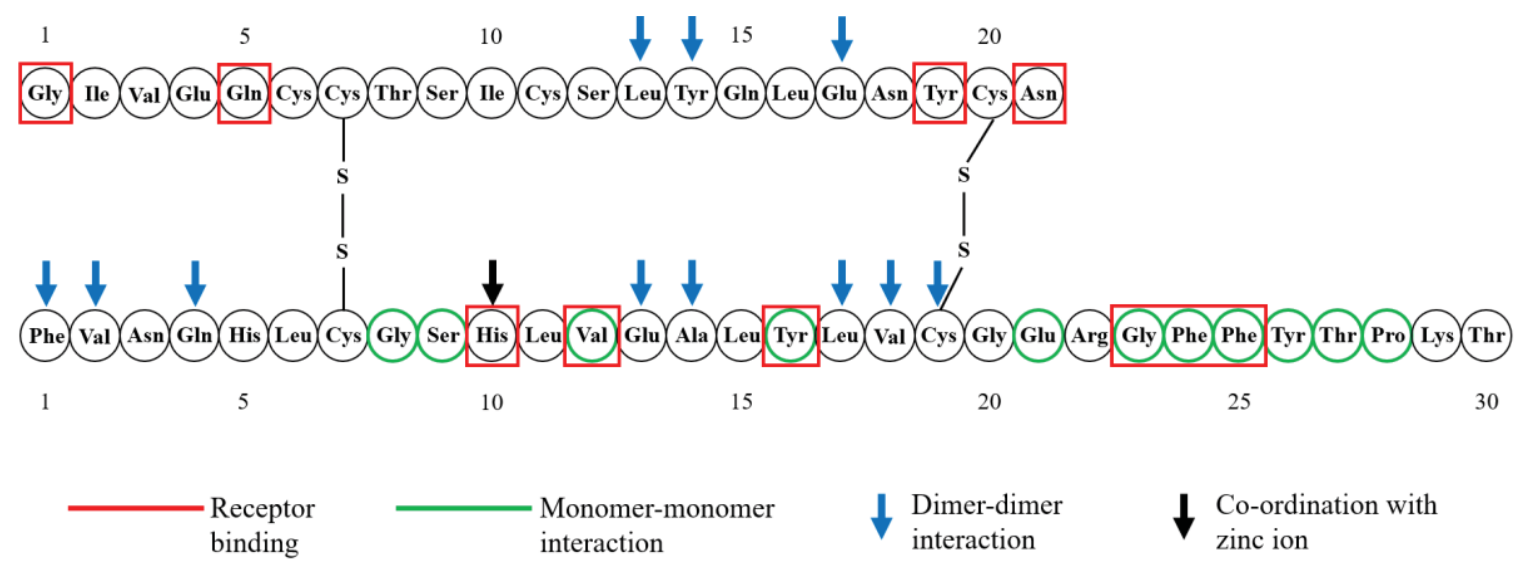

Figure 1-1. Primary structure of native human insulin

The green indicates residues participating in monomer-monomer interaction leading to dimerization, blue arrow indicates residue participating in dimer-dimer interaction to form hexamer, black arrow indicates residue participating in co-ordination complex with zinc ion and red indicates residues participating in insulin receptor binding.

Sources: Becker, R. H. (2007). Insulin glulisine complementing basal insulins: a review of structure and activity. Diabetes technology \& therapeutics, 9(1), 109-121. Brange, J., Owens, D. R., Kang, S., \& Vølund, A. (1990). Monomeric insulins and their experimental and clinical implications. Diabetes care, 13(9), 923-954. 
glucose concentration causes influx of a large amount of glucose inside the beta cells through glucose transporter GLUT-2 which is preferentially expressed in the pancreatic beta cell membrane [14]. This influx causes over production of cytosolic ATP which promotes the closure of ATP sensitive potassium channels on the cell membrane [15]. As a result, $\mathrm{K}^{+}$ions are accumulated inside the cells causing depolarization of the plasma membrane which in turn causes opening of the voltage-gated $\mathrm{Ca}^{2+}$ channels $[15,16]$. As a consequence, cytosolic $\mathrm{Ca}^{2+}$ concentration is raised and triggers exocytosis process by which insulin containing secretory vesicles fuse with the plasma membrane and secrete insulin hexamer [17].

The insulin hexamer is dissociated into monomer when secreted from the pancreas $[18,19]$. The insulin monomer is absorbed into the systemic circulation and reaches adipose and muscle tissues where it binds with its receptor to exert its glucose lowering effects on muscle and adipose tissues [20]. The amino acid residues A1, A5, A19, A21, B10, B12, B16 and B23-25 participate in receptor binding of insulin [12]. In a healthy person, insulin is continually secreted from the pancreas at a nearly constant rate and maintain constant plasma insulin level after food absorption is ceased [21]. This is called basal insulin secretion. After each meal, blood glucose level rises due to food absorption and causes a surge in insulin secretion from the pancreas to facilitate glucose utilization by the body which is called post-prandial insulin secretion [21].

Currently there are two types of insulin available in the market based on their duration of action: rapid-acting or bolus insulins including insulin lispro, aspart and glulisine which mimic the post-prandial insulin secretion and long-acting or basal insulins including insulin glargine, detemir, and degludec which mimic the basal insulin secretion from pancreas. Rapid-acting or bolus insulins are used after each meal to control the post-prandial rise in blood glucose level whereas basal or long-acting insulins are used to maintain stable blood glucose level during fasting state or between meals. The rapid-acting insulins require multiple injections in a day and long-acting insulins require once-daily injection for short-term glycemic control i.e. blood glucose concentration $<125 \mathrm{mg} / \mathrm{dL}$ and long-term glycemic control i.e. HbAlc $<7 \%$, respectively. Repeated daily injections can cause serious patient non-compliance leading to non-adherence to treatment and consequently, sub-optimal therapeutic outcomes [22]. To address these issues, substantial efforts have been made in the developments of injectable sustained release systems that can release insulin for days to weeks to maintain normoglycemia and eliminate the need of frequent dosing. Along with more conventional sustained release systems including microspheres and in situ forming depots which have been around for a few decades, several new technologies for sustained drug delivery including nanoparticles, composite systems and glucose responsive systems have also been investigated for sustained insulin release. Currently, a number of products have advanced to clinical trials with the potential to transform the current once-daily basal insulin therapy to once-weekly therapy. This thesis comprehensively reviews the current trends and recent advancements in the development of injectable insulin analogs and delivery systems from prototype design and preclinical studies to clinical trials and marketed products as well as provides perspectives on future research and product development in the field of long-lasting injectable insulin therapy. 


\section{CHAPTER 2. INJECTABLE INSULINS IN THE MARKET}

Since its discovery in 1922, insulin has been mainstay treatment for patients with diabetes mellitus. Insulin was first extracted from the pancreas of cows and pigs in 1921 by Frederick Banting and Charles Best. The extraction process was patented by Banting and Best and later they decided to merge with Eli Lilly when the demand of insulin for the treatment of diabetes surpassed their laboratory production limit [23]. Since then, bovine and porcine insulins were life-saving medicine for diabetes patients, but the short half-life (4-6 min) of insulin required frequent injection which was expensive as well as caused medication non-adherence among patients. Therefore, extensive research efforts were made to increase the duration of action of insulin between 1930-40. The first breakthrough was made possible by Hans Christian Hagedorn at Nordisk Insulin Laboratorium in 1936 [24]. He discovered that the action-time profile of injected insulin could be prolonged by the addition of protamine. Protein molecules usually bear charges because of the ionic nature of the amino acids. Therefore, different protein molecules are soluble in different $\mathrm{pH}$. The solubility of proteins is the least at its isoelectric point [25]. The addition of protamine in insulin increased its isoelectric point from 5.2 to close to physiological $\mathrm{pH}$ resulted in the precipitation of insulin upon subcutaneous injection. As a result, insulin was released slowly from the site of insulin precipitation. Further experiments suggested that addition of zinc in insulin-protamine mixture formed insulin crystals which further prolonged the insulin release from the injection site [26]. This discovery led to the commercialization of insulin-protamine-zinc formulation in 1950 by Nordisk which was called NPH (neutral protamine hagedorn) insulin. The NPH insulin maintains its effect for 10-16 h but its absorption rate is unpredictable with high initial burst and rapid fall from the peak concentration [27]. Therefore, NPH insulin is usually mixed with regular insulin to achieve smoother action-time profile and better glycemic control [28]. NPH insulin is the first long-acting insulin formulation introduced in the market.

However, the insulins made from cows and pigs were reported to elicit allergic reactions and immunological responses [29-32]. With the later advent of recombinant DNA technology, biosynthetic human insulin was invented to replace bovine and porcine insulins. Genentech was the first company to develop recombinant human insulin (RHI) in 1978 which was approved by FDA in 1982 but they did not commercialize the product by themselves. In 1983, Eli Lilly and Company marketed the product under the brand name Humulin ${ }^{\circledR}$ after FDA approval and it is considered the first genetically engineered biologic drug [24]. Later on, Eli Lilly also marketed their own recombinant NPH insulin followed by Novo Nordisk's recombinant human insulin and NPH. Recombinant human insulin is structurally and functionally similar to regular human insulin produced by natural pancreatic $\beta$ cells and also has a short half-life of 4-6 min [33]. To increase the half-life of the recombinant human insulin, change of the amino acid sequences in native insulin and conjugation with long chain fatty acids to native insulin have been the central strategies to design long-lasting insulin analog. In addition, excipients such as zinc, meta cresol, glycerol and protamine sulfate have also been used extensively in insulin formulation development because zinc promotes insulin hexamer formation $[10,11]$, 
meta cresol stabilizes insulin [34], glycerol is a tonicity adjuster [35], and protamine sulfate can increase the isoelectric point of insulin from 5.2 to close to physiological $\mathrm{pH}$ to form insulin precipitates after subcutaneous injection [26]. In this Chapter 2, I focus on the review of two major types of human insulin analogs that have been available in the market: rapid acting or mealtime, and long-acting or basal insulin analogs including their analog designs, excipients in the formulations, and devices for delivering the analogs.

Table 2-1 provides an overview of currently available insulins and insulin analogs with their action-time profile. [36]

\section{Insulin Analogs}

\section{Rapid-Acting Insulin Analogs}

Rapid-acting insulin analogs are a type of recombinant insulin that has rapid onset of action with immediate pharmacodynamic effect. The products available in the market that belong to this category are insulin lispro, aspart and glulisine, whose B chain's amino acid was modified to reduce zinc mediated hexamer formation which is observed in regular insulin [6]. As a result, these insulin analogs are released into the bloodstream rapidly after subcutaneous injection. In this way, these analogs mimic the prandial insulin secretion of the body, the natural insulin secretion by pancreas after each meal, and thus are prescribed by doctors to maintain the blood glucose level after meal. Compared to regular human insulin and NPH insulin, insulin lispro, aspart and glulisine have faster onset of action, higher peak concentration and shorter duration of action. Below are the detailed discussions of the features and functions of insulin lispro, aspart and glulisine.

\section{Insulin lispro}

The first-in-class rapid-acting insulin analog was insulin lispro which was marketed in 1996 by Eli Lilly under a trade name of Humalog ${ }^{\circledR}$. Insulin lispro was developed by interchange between proline and lysine at 28 and 29 position in B chain of regular insulin, respectively (Figure 2-1). The inversion of ProB28LysB29 resulted in destabilization and rapid dissociation of formed hexamers into monomers and dimers causing rapid absorption of insulin into the systemic circulation after subcutaneous injection [37]. In 2017, Sanofi received FDA approval for Admelog ${ }^{\circledR}$ which is the first short-acting "follow-on" product of insulin lispro. Admelog ${ }^{\circledR}$ has an amino acid sequence identical to Humalog ${ }^{\circledR}$ and showed similar pharmaceokinetic and pharmacodynamic profile in clinical trials [38].

\section{Insulin aspart}

The second addition in rapid-acting insulin analogs is insulin aspart which was

approved in 2000 and developed by Novo Nordisk under a trade name of Novolog ${ }^{\circledR}$. In 
Table 2-1. Currently approved insulin injectables available in the US market

\begin{tabular}{|c|c|c|c|c|c|c|c|c|}
\hline \multirow[b]{2}{*}{ Type } & \multirow[b]{2}{*}{$\begin{array}{l}\text { Insulin/Insulin } \\
\text { Analogs }\end{array}$} & \multirow[b]{2}{*}{ Trade Name } & \multirow[b]{2}{*}{$\begin{array}{l}\text { Manufacturer } \\
\text { (Approval Date) }\end{array}$} & \multicolumn{3}{|c|}{ Time of Action } & \multirow[b]{2}{*}{ Dosing Time } & \multirow[b]{2}{*}{$\begin{array}{l}\text { Route of } \\
\text { Administration }\end{array}$} \\
\hline & & & & Onset & Peak & Duration & & \\
\hline \multirow{8}{*}{$\begin{array}{l}\text { Rapid-acting or } \\
\text { mealtime } \\
\text { insulin analogs }\end{array}$} & Lispro & Humalog ${ }^{\circledR}$ & $\begin{array}{l}\text { Eli Lilly } \\
(1996)\end{array}$ & $15 \mathrm{~min}$ & $30-90 \mathrm{~min}$ & $3-5 h$ & $\begin{array}{l}3-5 \text { min } \\
\text { before meal }\end{array}$ & SC or IV \\
\hline & & Admelog ${ }^{\circledR}$ & $\begin{array}{l}\text { Sanofi } \\
(2017)\end{array}$ & $15 \mathrm{~min}$ & $30-90 \mathrm{~min}$ & $3-5 \mathrm{~h}$ & $\begin{array}{l}3-5 \text { min } \\
\text { before meal }\end{array}$ & SC or IV \\
\hline & Aspart & Novolog $^{\circledR}$ & $\begin{array}{l}\text { Novo Nordisk } \\
(2000)\end{array}$ & $15 \mathrm{~min}$ & $30-90 \mathrm{~min}$ & $3-5 \mathrm{~h}$ & $\begin{array}{l}0-15 \text { min } \\
\text { before meal }\end{array}$ & SC or IV \\
\hline & & Fiasp $^{\circledR}$ & $\begin{array}{l}\text { Novo Nordisk } \\
\text { (2017) }\end{array}$ & $2.5 \mathrm{~min}$ & $30-60 \mathrm{~min}$ & $3-5 \mathrm{~h}$ & $\begin{array}{l}0-15 \text { min } \\
\text { before meal }\end{array}$ & SC or IV \\
\hline & Gluisine & Apidra ${ }^{\circledR}$ & $\begin{array}{l}\text { Sanofi } \\
(2004)\end{array}$ & $15 \mathrm{~min}$ & $30-90 \mathrm{~min}$ & $3-5 \mathrm{~h}$ & $\begin{array}{l}0-15 \text { min } \\
\text { before meal }\end{array}$ & SC or IV \\
\hline & $\begin{array}{l}\text { Regular human } \\
\text { insulin (RHI) }\end{array}$ & $\begin{array}{l}\text { Humulin }{ }^{\circledR} \mathrm{R} \\
\text { (U-100) }\end{array}$ & $\begin{array}{l}\text { Eli Lilly } \\
(1982)\end{array}$ & $30-60 \mathrm{~min}$ & $2-3 \mathrm{~h}$ & $21 \mathrm{~h}$ & $\begin{array}{l}30 \text { min before } \\
\text { meal }\end{array}$ & $\mathrm{SC}$ \\
\hline & & Novolin ${ }^{\circledR} \mathrm{R}$ & $\begin{array}{l}\text { Novo Nordisk } \\
\text { (1991) }\end{array}$ & $30-60 \mathrm{~min}$ & $2-3 \mathrm{~h}$ & $10-16 \mathrm{~h}$ & $\begin{array}{l}\text { Once at } \\
\text { bedtime or } \\
\text { twice daily }\end{array}$ & $\mathrm{SC}$ \\
\hline & & $\begin{array}{l}\text { Humulin }{ }^{\circledR} \mathrm{R} \\
(\mathrm{U}-500)\end{array}$ & $\begin{array}{l}\text { Eli Lilly } \\
\text { (1994) }\end{array}$ & $<15 \min$ & $4-8 \mathrm{~h}$ & $\sim 24 \mathrm{~h}$ & $\begin{array}{l}\text { Once or twice } \\
\text { daily }\end{array}$ & $\mathrm{SC}$ \\
\hline \multirow[t]{7}{*}{$\begin{array}{l}\text { Long-acting or } \\
\text { basal insulin } \\
\text { analogs }\end{array}$} & $\begin{array}{l}\text { Neutral } \\
\text { protamine } \\
\text { Hagedorn } \\
(\mathrm{NPH})\end{array}$ & Humulin ${ }^{\circledR} \mathrm{N}$ & $\begin{array}{l}\text { Eli Lilly } \\
\text { (1982) }\end{array}$ & $2-4 \mathrm{~h}$ & $4-10 \mathrm{~h}$ & $10-16 \mathrm{~h}$ & $\begin{array}{l}\text { Once at } \\
\text { bedtime or } \\
\text { twice daily }\end{array}$ & $\mathrm{SC}$ \\
\hline & & Novolin ${ }^{\circledR} \mathrm{N}$ & $\begin{array}{l}\text { Novo Nordisk } \\
(1991)\end{array}$ & $2-4 \mathrm{~h}$ & $4-10 \mathrm{~h}$ & $10-16 \mathrm{~h}$ & $\begin{array}{l}\text { Once at } \\
\text { bedtime or } \\
\text { twice daily }\end{array}$ & $\mathrm{SC}$ \\
\hline & $\begin{array}{l}\text { Glargine } \\
(100 \mathrm{U} / \mathrm{ml})\end{array}$ & Lantus $^{\circledR}$ & $\begin{array}{l}\text { Sanofi } \\
(2000)\end{array}$ & $2-4 \mathrm{~h}$ & No peak & $\sim 24 \mathrm{~h}$ & $\begin{array}{l}\text { Once or twice } \\
\text { daily }\end{array}$ & $\mathrm{SC}$ \\
\hline & & Basaglar $^{\circledR}$ & $\begin{array}{l}\text { Eli Lilly } \\
(2015)\end{array}$ & $2-4 \mathrm{~h}$ & No peak & $\sim 24 \mathrm{~h}$ & $\begin{array}{l}\text { Once or twice } \\
\text { daily }\end{array}$ & $\mathrm{SC}$ \\
\hline & Detemir & Levemir $^{\circledR}$ & $\begin{array}{l}\text { Novo Nordisk } \\
(2005)\end{array}$ & $3-4 \mathrm{~h}$ & No peak & $20-24 \mathrm{~h}$ & $\begin{array}{l}\text { Once or twice } \\
\text { daily }\end{array}$ & $\mathrm{SC}$ \\
\hline & $\begin{array}{l}\text { Glargine } \\
(300 \mathrm{U} / \mathrm{ml})\end{array}$ & Toujeo $^{\circledR}$ & $\begin{array}{l}\text { Sanofi } \\
(2015)\end{array}$ & $6 \mathrm{~h}$ & No peak & $\sim 32 \mathrm{~h}$ & $\begin{array}{l}\text { Once or twice } \\
\text { daily }\end{array}$ & $\mathrm{SC}$ \\
\hline & Degludec & Tresiba $^{\circledR}$ & $\begin{array}{l}\text { Novo Nordisk } \\
(2015)\end{array}$ & $3-4 \mathrm{~h}$ & No peak & $\sim 42 \mathrm{~h}$ & Once daily & $\mathrm{SC}$ \\
\hline
\end{tabular}


Table 2-1. (Continued)

\begin{tabular}{|c|c|c|c|c|c|c|c|c|}
\hline \multirow[b]{2}{*}{ Type } & \multirow[b]{2}{*}{$\begin{array}{l}\text { Insulin/Insulin } \\
\text { Analogs }\end{array}$} & \multirow[b]{2}{*}{ Trade Name } & \multirow[b]{2}{*}{$\begin{array}{l}\text { Manufacturer } \\
\text { (Approval Date) }\end{array}$} & \multicolumn{3}{|c|}{ Time of Action } & \multirow[b]{2}{*}{ Dosing Time } & \multirow[b]{2}{*}{$\begin{array}{l}\text { Route of } \\
\text { Administration }\end{array}$} \\
\hline & & & & Onset & Peak & Duration & & \\
\hline \multirow[t]{6}{*}{$\begin{array}{l}\text { Premixed } \\
\text { insulins }\end{array}$} & $\begin{array}{l}70 \% \text { neutral } \\
\text { protamine } \\
\text { hagedorn and } \\
30 \% \text { regular } \\
\text { human insulin }\end{array}$ & $\begin{array}{l}\text { Humulin }^{\circledR} \\
70 / 30\end{array}$ & $\begin{array}{l}\text { Eli Lilly } \\
\text { (1989) }\end{array}$ & $30-60 \mathrm{~min}$ & $2-6 \mathrm{~h}$ & $12-18 \mathrm{~h}$ & $\begin{array}{l}\text { Twice daily } \\
\text { before } \\
\text { breakfast and } \\
\text { dinner }\end{array}$ & $\mathrm{SC}$ \\
\hline & & $\begin{array}{l}\text { Novolin }^{\circledR} \\
70 / 30\end{array}$ & $\begin{array}{l}\text { Novo Nordisk } \\
\text { (1991) }\end{array}$ & $30-60 \mathrm{~min}$ & $2-6 \mathrm{~h}$ & $12-18 \mathrm{~h}$ & $\begin{array}{l}\text { Twice daily } \\
\text { before } \\
\text { breakfast and } \\
\text { dinner }\end{array}$ & $\mathrm{SC}$ \\
\hline & $\begin{array}{l}75 \% \text { insulin } \\
\text { lispro protamine } \\
\text { and } 25 \% \text { lispro }\end{array}$ & $\begin{array}{l}\text { HumaLog }{ }^{\circledR} \\
\text { Mix 75/25 }\end{array}$ & Eli Lilly (1999) & $5-15 \min$ & $2-4 \mathrm{~h}$ & $14-24 \mathrm{~h}$ & $\begin{array}{l}\text { Twice daily } \\
\text { before } \\
\text { breakfast and } \\
\text { dinner }\end{array}$ & $\mathrm{SC}$ \\
\hline & $\begin{array}{l}50 \% \text { insulin } \\
\text { lispro protamine } \\
\text { and } 50 \% \text { lispro }\end{array}$ & $\begin{array}{l}\text { HumaLog }^{\circledR} \\
\text { Mix 50/50 }\end{array}$ & Eli Lilly (1999) & $5-15 \min$ & $2-4 \mathrm{~h}$ & $14-24 \mathrm{~h}$ & $\begin{array}{l}\text { Twice daily } \\
\text { before } \\
\text { breakfast and } \\
\text { dinner }\end{array}$ & $\mathrm{SC}$ \\
\hline & $\begin{array}{l}70 \% \text { insulin } \\
\text { aspart protamine } \\
\text { and } 30 \% \text { aspart }\end{array}$ & $\begin{array}{l}\text { NovoLog }^{\circledR} \\
\text { Mix } 70 / 30\end{array}$ & $\begin{array}{l}\text { Novo Nordisk } \\
\text { (2001) }\end{array}$ & $5-15 \mathrm{~min}$ & $2-4 \mathrm{~h}$ & $14-24 \mathrm{~h}$ & $\begin{array}{l}\text { Twice daily } \\
\text { before } \\
\text { breakfast and } \\
\text { dinner }\end{array}$ & $\mathrm{SC}$ \\
\hline & $\begin{array}{l}70 \% \text { insulin } \\
\text { degludec } \\
\text { protamine and } \\
30 \% \text { aspart }\end{array}$ & $\begin{array}{l}\text { Ryzodeg }^{\circledR} \\
70 / 30\end{array}$ & $\begin{array}{l}\text { Novo Nordisk } \\
\text { (2015) }\end{array}$ & $15 \mathrm{~min}$ & $30-90 \mathrm{~min}$ & $>24 \mathrm{~h}$ & $\begin{array}{l}\text { Once or twice } \\
\text { daily before } \\
\text { meal }\end{array}$ & $\mathrm{SC}$ \\
\hline
\end{tabular}

Notes: $\mathrm{SC}=$ Subcutaneous, IV=Intravascular.

Sources: Pechenov, S., Bhattacharjee, H., Yin, D., Mittal, S., \& Subramony, J. A. (2017). Improving drug-like properties of insulin and GLP-1 via molecule design and formulation and improving diabetes management with device \& drug delivery. Advanced drug delivery reviews, 112, 106-122. Jayakrishnapillai, P. V., Nair, S. V., \& Kamalasanan, K. (2017). Current trend in drug delivery considerations for subcutaneous insulin depots to treat diabetes. Colloids and Surfaces B: Biointerfaces, 153, 123-131. Yu, J., Qian, C., Zhang, Y., Cui, Z., Zhu, Y., Shen, Q., Ligler, F.S., Buse, J.B. and Gu, Z. (2017). Hypoxia and H2O2 dual-sensitive vesicles for enhanced glucose-responsive insulin delivery. Nano letters, 17(2), 733-739. American Diabetes 


\section{Table 2-1. (Continued)}

Association (2018). Lipska, K. J., Hirsch, I. B., \& Riddle, M. C. (2017). Human insulin for type 2 diabetes: an effective, lessexpensive option. Jama, 318(1), 23-24. Mathieu, C., Gillard, P., \& Benhalima, K. (2017). Insulin analogs in type 1 diabetes mellitus: getting better all the time. Nature Reviews Endocrinology, 13(7), 385. 
A) Rapid-acting insulin analogs

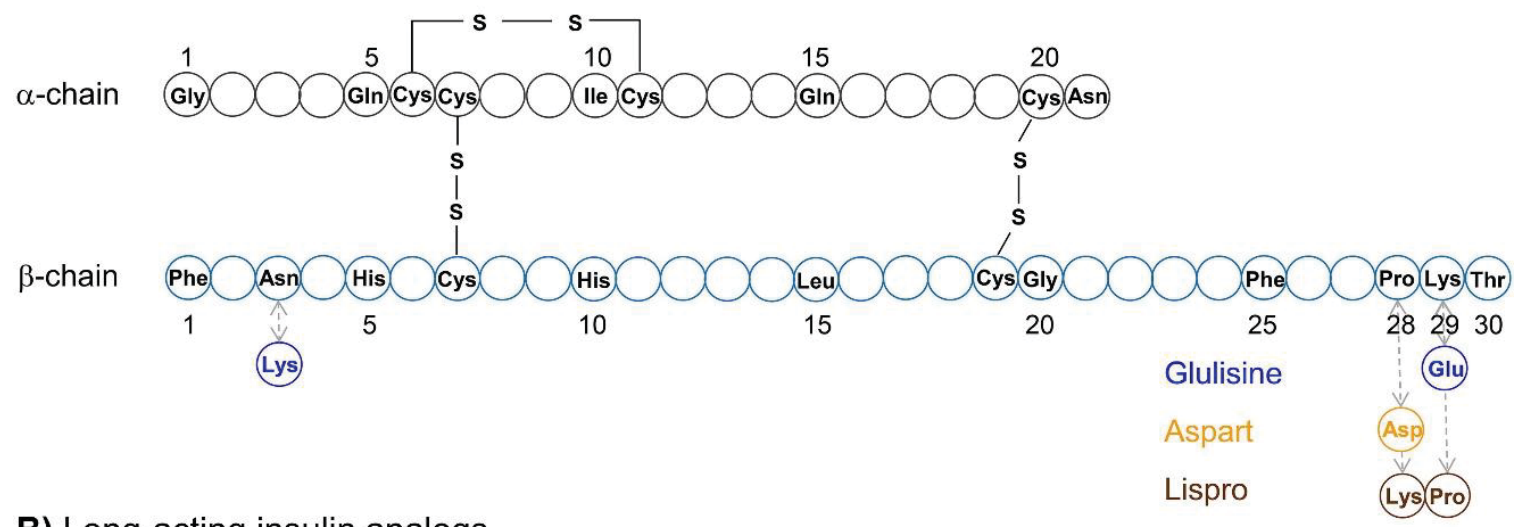

B) Long-acting insulin analogs

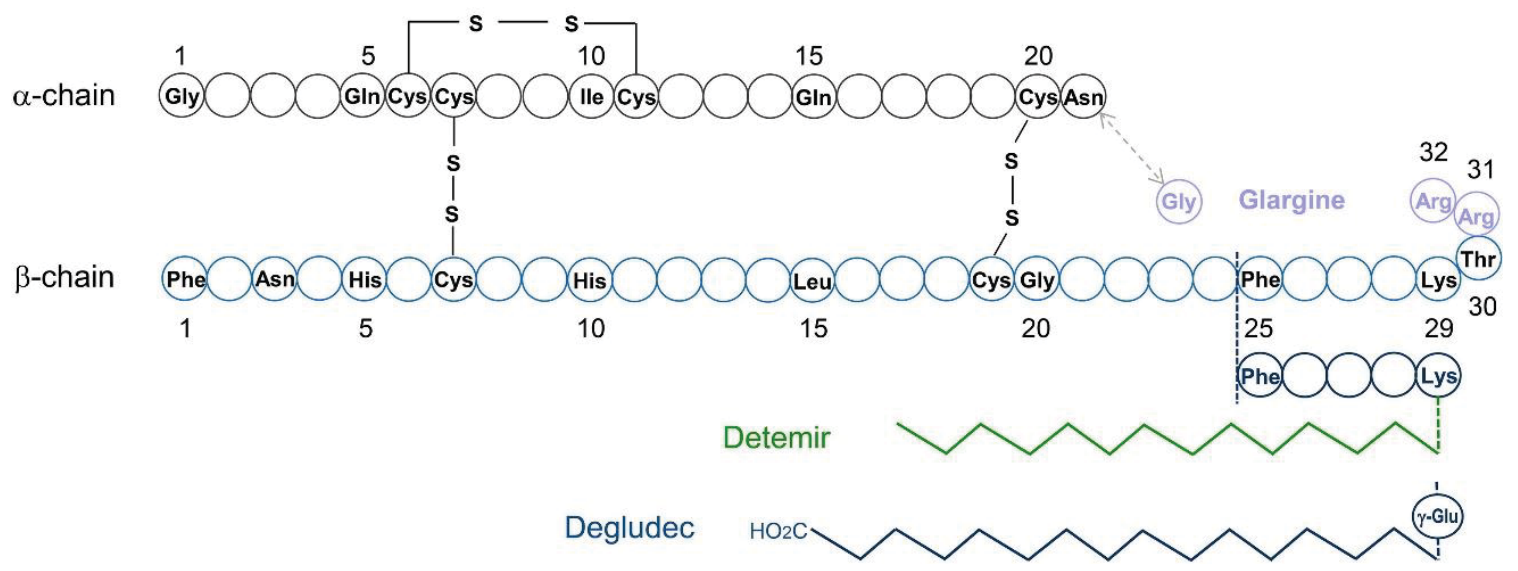

Figure 2-1. Structural modifications of human insulin to develop insulin analogs

A: The amino acid modifications in rapid-acting insulin analogs decrease hexamer formation and increase insulin solubility and absorption from subcutaneous space after injection causing rapid action-time profile.

B: The amino acid modifications and fatty acid conjugation in long-acting insulin analogs lead to formation of multihexamer structures in subcutaneous space after injection and reversible albumin-binding in the circulation, respectively, causing prolonged duration of action.

Reprinted from Advanced drug delivery reviews, 112, Pechenov, S., Bhattacharjee, H., Yin, D., Mittal, S. and Subramony, J.A., Improving drug-like properties of insulin and GLP-1 via molecule design and formulation and improving diabetes management with device \& drug delivery, 106-122, 2017, with permission from Elsevier. 
insulin aspart, proline at B28 position of regular insulin was substituted with aspartic acid (Figure 2-1). As a result, the insulin's hexamer formation is inhibited, isoelectric point is reduced and solubility at physiological $\mathrm{pH}$ is increased due to the negative charge of aspartic acid, and thus insulin is rapidly available in the bloodstream upon subcutaneous injection [39]. The pharmacokinetic-pharmacodynamic profile of insulin aspart is similar to that of insulin lispro [40]. In 2017, Novo Nordisk received FDA approval for its insulin aspart brand-named Fiasp ${ }^{\circledR}$ which has additional nicotinamide (vitamin B3) and arginine as excipients in its formulation, to increase the initial absorption rate of insulin [41]. Fiasp ${ }^{\circledR}$ acts faster than Novolog ${ }^{\circledR}$ with 2.5 vs. 15 min onset of appearance in the bloodstream $[6,42]$.

\section{Insulin glulisine}

The most recent rapid-acting insulin analog is insulin glulisine which was approved by FDA in 2004 and introduced to the market in 2006 by Sanofi under a trade name Apidra ${ }^{\circledR}$. In insulin glulisine, the asparagine at position B3 and lysine at position B29 of regular insulin were replaced by lysine and glutamic acid, respectively to decrease the isoelectric point and thus increase the solubility of the insulin (Figure 2-1) [12]. Insulin glulisine demonstrates slightly faster onset of action than insulin lispro and aspart due to the absence of zinc in its formulation (zinc promotes hexamer formation causing slow availability of functional insulin monomer) $[12,43]$.

\section{Long-Acting Insulin Analogs}

Long-acting insulin analogs are a type of recombinant human insulin that can continuously provide exogenous basal insulin to maintain normoglycemia for up to $24 \mathrm{~h}$ $[22,44,45]$. The products available in the market that belong to this category are insulin glargine, detemir, and degludec. The design strategies for these long-acting insulin analogs include modification of the amino acid sequence of insulin to facilitate hexamer formation and conjugation of fatty acid to the insulin chain to increase the circulation time of insulin (half-life) in the bloodstream via reversible binding with albumin [6]. Below are the detailed discussions of the features and functions of insulin glargine, detemir, and degludec.

\section{Insulin glargine $(100 \mathrm{U} / \mathrm{mL})$}

The first long acting insulin analog introduced in the market was Sanofi's insulin glargine which was approved by FDA in 2000 and marketed under a trade name Lantus ${ }^{\circledR}$. In insulin glargine $100 \mathrm{U} / \mathrm{mL}$, asparagine at A20 position of regular insulin was replaced with glycine and two arginine molecules were added to the $\mathrm{B}$ chain of regular insulin to shift the isoelectric point of insulin close to physiological $\mathrm{pH}$ (Figure 2-1) [46]. As a result, insulin glargine $100 \mathrm{U} / \mathrm{mL}$ is soluble in acidic $\mathrm{pH}$ in the vial but precipitates to form zinc mediated hexamer aggregates leading to slow insulin release after subcutaneous injection. Insulin glargine $100 \mathrm{U} / \mathrm{mL}$ demonstrated a flatter and longer pharmacokinetic-pharmacodynamic profile than NPH insulin and can decrease the risk of 
nocturnal hypoglycemia in most patients in once daily-dosing [47, 48]. In 2015, FDA approved the first "follow-on" product of insulin glargine developed by Eli Lilly and Company and marketed as Basaglar ${ }^{\circledR}$. Basaglar ${ }^{\circledR}$ and Lantus ${ }^{\circledR}$ are structurally identical and have similar efficacy and safety profile [49].

\section{Insulin detemir}

Insulin detemir is the second long-acting insulin analog approved by FDA (2005) and commercialized by Novo Nordisk under a trade name Levemir ${ }^{\circledR}$. In detemir, threonine was removed from the position B30 and myristoyl fatty acid (C14) was conjugated to B29 lysine of regular insulin to promote di-hexamer formation of insulin with zinc after subcutaneous injection (Figure 2-1). The di-hexamers are dissociated into hexamers and then slowly into monomers to be absorbed in the systemic circulation. In addition, the conjugated fatty acid facilitates reversible binding of insulin with albumin in the systemic circulation to further prolong the action of detemir. In clinical trials, insulin detemir showed better glycemic control than NPH insulin [48, 50]. Although same glycemic control was achieved by insulin detemir in higher dose when compared with insulin glargine $100 \mathrm{U} / \mathrm{mL}$, insulin detemir causes less weight gain than insulin glargine $100 \mathrm{U} / \mathrm{mL}$ in clinical trials $[51,52]$.

Both insulin glargine $100 \mathrm{U} / \mathrm{mL}$ and insulin detemir have advantages over NPH insulin because of their longer duration of action, lesser inter- and intra-individual variabilities and fewer episodes of hypoglycemic events [33]. In comparison with insulin glargine $100 \mathrm{U} / \mathrm{mL}$, insulin detemir has even less pronounced inter- and intra-individual variabilities [53]. Although insulin glargine $100 \mathrm{U} / \mathrm{mL}$ and detemir are reported to provide glycemic control for $24 \mathrm{~h}$, more frequent than once-daily regimen has been observed to provide improved glycemic control in clinical practice [51, 54]. Considering these issues, newer basal insulin analogs have been developed with a view to providing better glycemic control with fewer injections by improving patient compliance [55]. At present, there are two such basal insulin analogs available in the US market: insulin glargine $300 \mathrm{U} / \mathrm{mL}$ and insulin degludec $100 \mathrm{U} / \mathrm{mL}$ and $300 \mathrm{U} / \mathrm{mL}$. They are usually prescribed as once-daily injection.

\section{Insulin glargine $(300 \mathrm{U} / \mathrm{mL})$}

Insulin glargine injection $300 \mathrm{U} / \mathrm{mL}$ is a highly concentrated version of Lantus ${ }^{\circledR}$ available in $300 \mathrm{U} / \mathrm{mL}$. It was approved by FDA in 2015 and is currently marketed by Sanofi under a trade name of Toujeo ${ }^{\circledR}$. After subcutaneous injection, insulin glargine 300 $\mathrm{U} / \mathrm{mL}$ precipitates at physiological $\mathrm{pH}$ to form concentrated insulin-zinc hexamer aggregates which are more compact than aggregates formed by insulin glargine $100 \mathrm{U} / \mathrm{mL}$ (Figure 2-2). Therefore, insulin glargine $300 \mathrm{U} / \mathrm{mL}$ showed longer action than NPH and insulin glargine $100 \mathrm{U} / \mathrm{mL}$ [56]. In clinical studies, insulin glargine $300 \mathrm{U} / \mathrm{mL}$ demonstrated better steady-state pharmacokinetic-pharmacodynamic profile, better $24 \mathrm{~h}$ coverage irrespective of the injection time with less increase in the glucose level in the last $4 \mathrm{~h}$, and reduced risk of nocturnal hypoglycemia than insulin glargine $100 \mathrm{U} / \mathrm{mL}$ [57, 58]. 


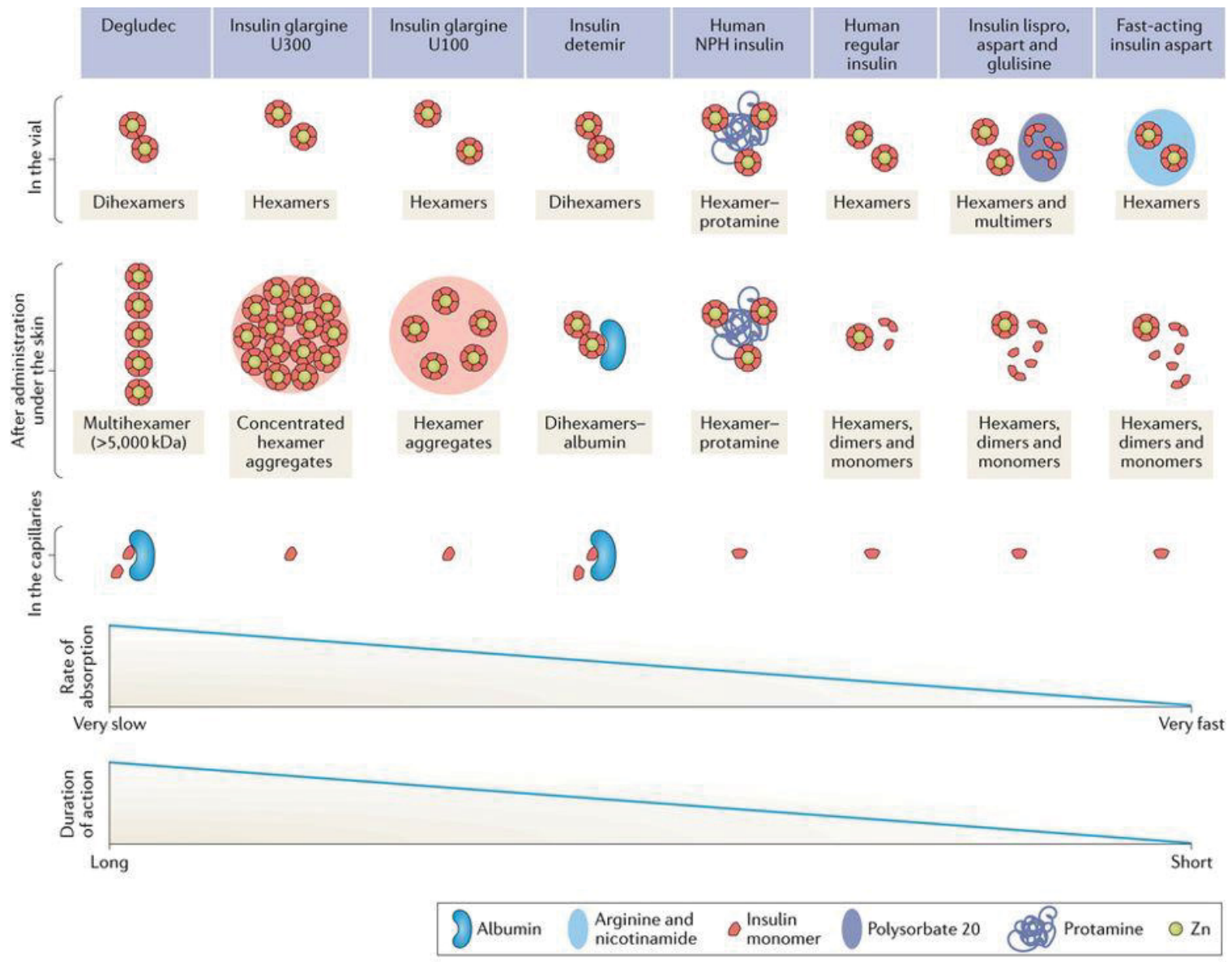

Nature Reviews | Endocrinology

Figure 2-2. Protraction mechanism of insulin analogs

The effect of self-aggregation nature of insulin and insulin analogs on their rate of absorption and duration of action has been shown. Preventing hexamer formation by amino acid modification in rapid acting analogs causes rapid dissociation of hexamer into monomer and dimer resulted in fast absorption rate and short duration of action (lispro, aspart and glulisine). Positively charged protamine stabilizes native insulin hexamer and causes slower insulin release and longer duration of action (NPH insulin). Amino acid modification and fatty acid conjugation in long acting insulin analogs cause formation of dihexamer (detemir), hexamer aggregates (glargine) and multi-hexamer chains (degludec) and slows down the absorption and prolongs duration of action. Fatty acid conjugation further extends the half-life by binding with albumin in the circulation (detemir and degludec).

Reprinted by permission from Nature Publishing Group: Springer Nature, Nature Review Endocrinology, Insulin analogs in type 1 diabetes mellitus: getting better all the time, Mathieu, C., Gillard, P., \& Benhalima, K., 2017. 


\section{Insulin degludec}

Insulin degludec was developed by Novo Nordisk as a longer acting version of their previous analog, insulin detemir. Insulin deguldec is available in $100 \mathrm{U} / \mathrm{ml}$ and 200 $\mathrm{U} / \mathrm{ml}$ formulations and approved for once-daily dosing regimen. It was approved in 2015 and marketed under the trade name of Tresiba ${ }^{\circledR}$. In degludec, Threonine at position B30 of regular insulin was removed and a C16 fatty acid was attached to the LysB29 via a Glutamic acid spacer (Figure 2-1) [43]. In the presence of phenol and zinc, insulin degludec forms dihexamer in the vial. Following subcutaneous injection, phenol is diffused out resulting in the formation of multi-hexamer chains. Multihexamers are gradually dissociated into dimers and monomers by the removal of zinc which provides slow and continuous delivery of insulin degludec into the circulation for a prolonged time (Figure 2-3). The protraction is further achieved by reversible binding of degludec with circulating albumin $[59,60]$ (Figure 2-2). In clinical trials, insulin glargine demonstrated a flat and stable glucose lowering effect [61], four-fold decrease in within-subject variability in glucose lowering effect [61] and reduction in nocturnal hypoglycemia when compared with insulin glargine [62]. Till date, insulin degludec is the longest acting insulin analog available in the market with a duration of action about $42 \mathrm{~h}$ with a flexible dosing regimen. As a result, patients who are on once daily insulin degludec dosing regimen, in case of missing dose, can take the dose with time intervals of minimum 8 hours to maximum 40 hours without compromising the glycemic control $[63,64]$. On the contrary, insulin glargine and detemir are required to be injected every day (often twicedaily) at the same time to maintain normoglycemia [64].

\section{Premixed Insulins}

Premixed insulins are developed by combining regular human insulin or rapid acting analogs with its protamine complex to achieve better glycemic control and limit the number of injections per day. Currently, there are six premixed insulins available in the US market (Table 2-1). Regular insulin based premixed formulations (Novolin ${ }^{\circledR}$ 70/30 and Humulin ${ }^{\circledR} 70 / 30$ ) are prepared by mixing $70 \%$ NPH insulin and $30 \%$ regular human insulin. Premixed formulations prepared from insulin analogs (NovoLog ${ }^{\circledR}$ Mix 70/30, Humalog ${ }^{\circledR}$ Mix 75/25 and Humalog ${ }^{\circledR}$ Mix 50/50) usually contain rapid acting analogs mixed with its protamine complex in variable amount and they usually demonstrate shorter onset and longer duration of action compared to regular premixed preparations. In clinical trial, one injection of premixed insulin decreased HbAlc level significantly $(0.2 \%)$ compared to one injection of long-acting and one injection of short-acting insulin [65]. Also, premixed insulin analogs have been found to provide better post-prandial glycemic control compared to premixed human insulin, although longer-term glycemic control was comparable for both [66]. Patients usually prefer premixed insulin because of less number of injections, however, they are inconvenient for intensive insulin regimens which may require full basal bolus regimen which is up to 4 injections per day [65]. In this regard, Ryzodeg ${ }^{\circledR} 70 / 30$, a premixed insulin with 70\% insulin degludec and $30 \%$ insulin aspart, showed successful glycemic control with fewer injections than a basalbolus regimen with significantly less weight gain and lower daily insulin dose $(12 \%)$ in 


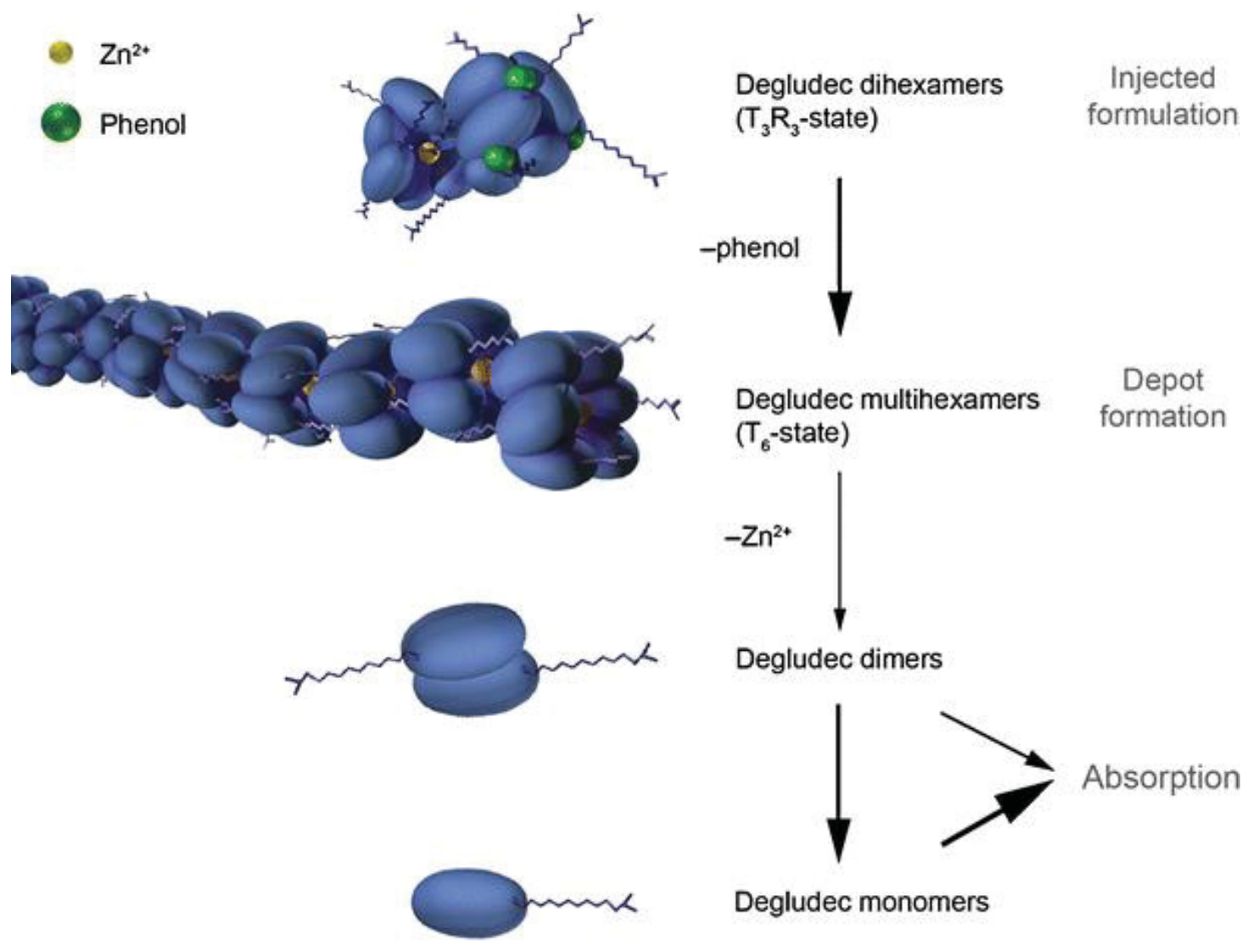

Figure 2-3. Protraction mechanism of insulin degludec

Insulin degludec remains as dimer in vial in the presence of zinc and phenol. Upon subcutaneous injection, phenol is diffused out and multi-hexamer chains are formed. Slow removal of zinc causes dissociation of multihexamer chains into monomer and dimer for absorption.

Reprinted with open access permission. Jonassen, I., Havelund, S., Hoeg-Jensen, T., Steensgaard, D. B., Wahlund, P. O., \& Ribel, U. (2012). Design of the novel protraction mechanism of insulin degludec, an ultra-long-acting basal insulin. Pharmaceutical research, 29(8), 2104-2114. 
clinical trial [67].

\section{Excipients in Long-Acting Insulin Analog Formulations}

In order to promote hexamer formation and albumin binding to achieve longer action-time profile, the amino acid modification and fatty acid conjugation are usually done in B26-30 of insulin residues which preserves its biological activity $[68,69]$. Various excipients are also added to the insulin formulations to stabilize the hexamer (Table 2-2). Thus, excipients, along with structure modifications, also play a key role in formulation development of long acting insulin products.

However, insulin undergoes fibrillation when exposed to elevated temperature, agitation, low $\mathrm{pH}$, organic solvents and increased ionic strength [70, 71]. Insulin fibrillation is a limiting factor in long term storage of marketed insulin preparations and predominantly occurs when insulin remains in its monomeric state [72]. Upon long term storage, conformational distortion of the monomers leads to partially folded intermediate and this partial fold may unfold completely or form amyloidogenic nuclei which ultimately leads to the formation of insulin fibril/filament (Figure 2-4) [73]. To overcome this problem, insulin needs to remain in its hexameric form in the marketed preparations and addition of zinc and phenolic compounds such as phenol and meta cresol to the insulin formulations facilitates this hexamer formation by exploiting the selfassociation nature of insulin monomers $[72,74]$. Therefore, all long acting insulin formulations available in the market contain zinc, glycerol and phenol or meta cresol or both. As mentioned earlier, addition of zinc promotes hexamer formation while glycerol is used to adjust the tonicity of the formulation. Phenol and meta cresol are primarily used as preservative as well as hexamer stabilizer in the formulation. However, NPH insulin formulation contains protamine sulfate which, as previously discussed, is used to increase the isoelectric point from 5.2 to close to physiological $\mathrm{pH}$ and therefore, insulin is precipitated and forms depot after subcutaneous injection [26]. Addition of phenolic compounds is especially important for degludec and detemir formulations because high concentration of phenolic compounds directs insulin-zinc hexamer to adopt a specific conformation that only allows di-hexamer formation of these analogs in the vial $[75,76]$. This process is also driven by anions such as chloride ion and therefore, sodium chloride is also added to detemir and degludec formulation [76]. Besides, Lantus ${ }^{\circledR}$ (insulin glargine) formulation contains polysorbate 20, a surfactant, which is used to prevent turbidity in the formulation [77]. Sodium hydroxide or hydrochloric acid is used to adjust the formulation $\mathrm{pH}$ while dibasic sodium phosphate is used as a buffering agent to maintain the $\mathrm{pH}$.

\section{Devices for Delivering Insulin Analogs}

Insulin is commonly administered through subcutaneous route due to the ease of self-administration and it is usually delivered using different methods such as vial and syringes, insulin pens, jet injectors and insulin pumps. The most common method of 
Table 2-2. Excipients in long-acting insulin formulations

\begin{tabular}{|c|c|c|c|c|}
\hline $\begin{array}{l}\text { Insulin or } \\
\text { Insulin } \\
\text { Analogs }\end{array}$ & $\begin{array}{l}\text { Trade } \\
\text { Name }\end{array}$ & $\begin{array}{l}\text { Excipients } \\
\text { (per ml) }\end{array}$ & $\begin{array}{l}\text { Physical } \\
\text { Appearance }\end{array}$ & Ref. \\
\hline $\begin{array}{l}\text { Neutral } \\
\text { protamine } \\
\text { Hagedorn } \\
(\mathrm{NPH}) \\
(5808 \mathrm{Da})\end{array}$ & $\begin{array}{l}\text { Humulin }^{\circledR} \\
\mathrm{N}\end{array}$ & $\begin{array}{l}\text { Human insulin recombinant: } 100 \mathrm{U} \text { (Escherichia } \\
\text { coli), Protamine sulfate: } 0.35 \mathrm{mg} \text {, Glycerol: } 16 \mathrm{mg} \text {, } \\
\text { Dibasic sodium phosphate: } 3.78 \mathrm{mg} \text {, Metacresol: } \\
1.6 \mathrm{mg} \text {, Phenol: } 0.65 \mathrm{mg} \text {, Zinc: } 0.025 \mathrm{mg} \text { (ZnO), } \\
\text { Water for injection, Sodium hydroxide and/or } \\
\text { hydrochloric acid to adjust pH to } 7-7.5\end{array}$ & $\begin{array}{l}\text { White } \\
\text { suspension }\end{array}$ & [78] \\
\hline \multirow{3}{*}{$\begin{array}{l}\text { Insulin } \\
\text { Glargine } \\
(100 \\
\text { U/ml }) \\
(6063 \mathrm{Da})\end{array}$} & $\begin{array}{l}\text { Novolin }^{\circledR} \\
\mathrm{N}\end{array}$ & $\begin{array}{l}\text { Human insulin: } 100 \mathrm{U} \text { (Saccharomyces cerevisiae), } \\
\text { Protamine sulfate: } 0.35 \mathrm{mg} \text {, Zinc: } 0.0335 \mathrm{mg} \text {, } \\
\text { Metacresol: } 1.6 \mathrm{mg} \text {, Phenol: } 0.65 \mathrm{mg} \text {, Glycerol: } 16 \\
\text { mg, Dibasic sodium phosphate dihydrate: } 2.4 \mathrm{mg} \text {, } \\
\text { Water for injection, Sodium hydroxide ( } 2 \mathrm{~N} \text { ) and } \\
\text { hydrochloric acid (2N) to adjust } \mathrm{pH} \text { to } 7.1-7.5\end{array}$ & $\begin{array}{l}\text { White and } \\
\text { cloudy } \\
\text { suspension }\end{array}$ & [79] \\
\hline & Lantus $^{\circledR}$ & $\begin{array}{l}\text { Insulin glargine recombinant: } 100 \mathrm{U} \text { ((Escherichia } \\
\text { coli), Zinc: } 0.03 \mathrm{mg} \text {, Metacresol: } 2.7 \mathrm{mg} \text {, Glycrol } \\
(85 \%): 20 \mathrm{mg} \text {, Polysorbate } 20: 0.02 \mathrm{mg} \text {, Water for } \\
\text { injection, Sodium hydroxide and/or hydrochloric } \\
\text { acid to adjust pH to } \sim 4 \\
* 3 \mathrm{ml} \text { prefilled pen does not contain polysorbate } 20 \text {. } \\
\text { All other excipient amounts are same. }\end{array}$ & $\begin{array}{l}\text { Clear } \\
\text { aqueous } \\
\text { fluid }\end{array}$ & [80] \\
\hline & Basaglar $^{\circledR}$ & $\begin{array}{l}\text { Insulin glargine recombinant: } 100 \mathrm{U} \text { (Escherichia } \\
\text { coli), Zinc: } 0.03 \mathrm{mg} \text {, Metacresol: } 2.7 \mathrm{mg} \text {, Glycrol } \\
(85 \%): 17 \mathrm{mg} \text {, Water for injection, Sodium } \\
\text { hydroxide and/or hydrochloric acid to adjust } \mathrm{pH} \text { to } \\
4\end{array}$ & $\begin{array}{l}\text { Colorless } \\
\text { aqueous } \\
\text { solution }\end{array}$ & [81] \\
\hline $\begin{array}{l}\text { Detemir } \\
(5916.9 \\
\text { Da) }\end{array}$ & Levemir $^{\circledR}$ & $\begin{array}{l}\text { Insulin detemir recombinant (followed by chemical } \\
\text { modification): } 100 \mathrm{U} \text { (Saccharomyces cerevisiae), } \\
\text { Zinc: } 0.0654 \mathrm{mg} \text {, Metacresol: } 2.06 \mathrm{mg} \text {, Glycerol } \\
\text { ( } 85 \%): 16 \mathrm{mg} \text {, Phenol: } 1.8 \mathrm{mg} \text {, Disodium phosphate } \\
\text { dihydrate: } 0.89 \mathrm{mg} \text {, Sodium chloride: } 1.17 \mathrm{mg} \text {, } \\
\text { Water for injection, Sodium hydroxide and/or } \\
\text { hydrochloric acid to adjust pH to } 7.4\end{array}$ & $\begin{array}{l}\text { Colorless } \\
\text { aqueous } \\
\text { solution }\end{array}$ & [82] \\
\hline $\begin{array}{l}\text { Glargine } \\
(300 \\
\mathrm{U} / \mathrm{ml}) \\
(6063 \mathrm{Da})\end{array}$ & Toujeo $^{\circledR}$ & $\begin{array}{l}\text { Insulin glargine recombinant: } 300 \mathrm{U} \text { (Escherichia } \\
\text { coli), Zinc: } 0.090 \mathrm{mg} \text {, Metacresol: } 2.7 \mathrm{mg} \text {, Glycerol } \\
(85 \%): 20 \mathrm{mg} \text {, Water for injection } \\
\text { Sodium hydroxide and/or hydrochloric acid to } \\
\text { adjust pH to } \sim 4\end{array}$ & $\begin{array}{l}\text { Clear } \\
\text { aqueous } \\
\text { fluid }\end{array}$ & [83] \\
\hline $\begin{array}{l}\text { Degludec } \\
\text { (6103.97 } \\
\text { Da) }\end{array}$ & Tresiba $^{\circledR}$ & $\begin{array}{l}\text { Insulin degludec recombinant (followed by } \\
\text { chemical modification): } 100 \mathrm{U} \text { (Saccharomyces } \\
\text { cerevisiae), Zinc: } 0.0327 \mathrm{mg} \text {, Metacresol: } 1.72 \mathrm{mg} \text {, } \\
\text { Glycerol: } 19.6 \mathrm{mg} \text {, Phenol: } 1.50 \mathrm{mg} \text {, Di sodium } \\
\text { phosphate dihydrate: } 0.89 \mathrm{mg} \text {, Sodium chloride: } \\
1.17 \mathrm{mg} \text {, Water for injection } \\
\text { Sodium hydroxide and/or hydrochloric acid to } \\
\text { adjust pH to } 7.6\end{array}$ & $\begin{array}{l}\text { Colorless } \\
\text { aqueous } \\
\text { solution }\end{array}$ & [84] \\
\hline
\end{tabular}




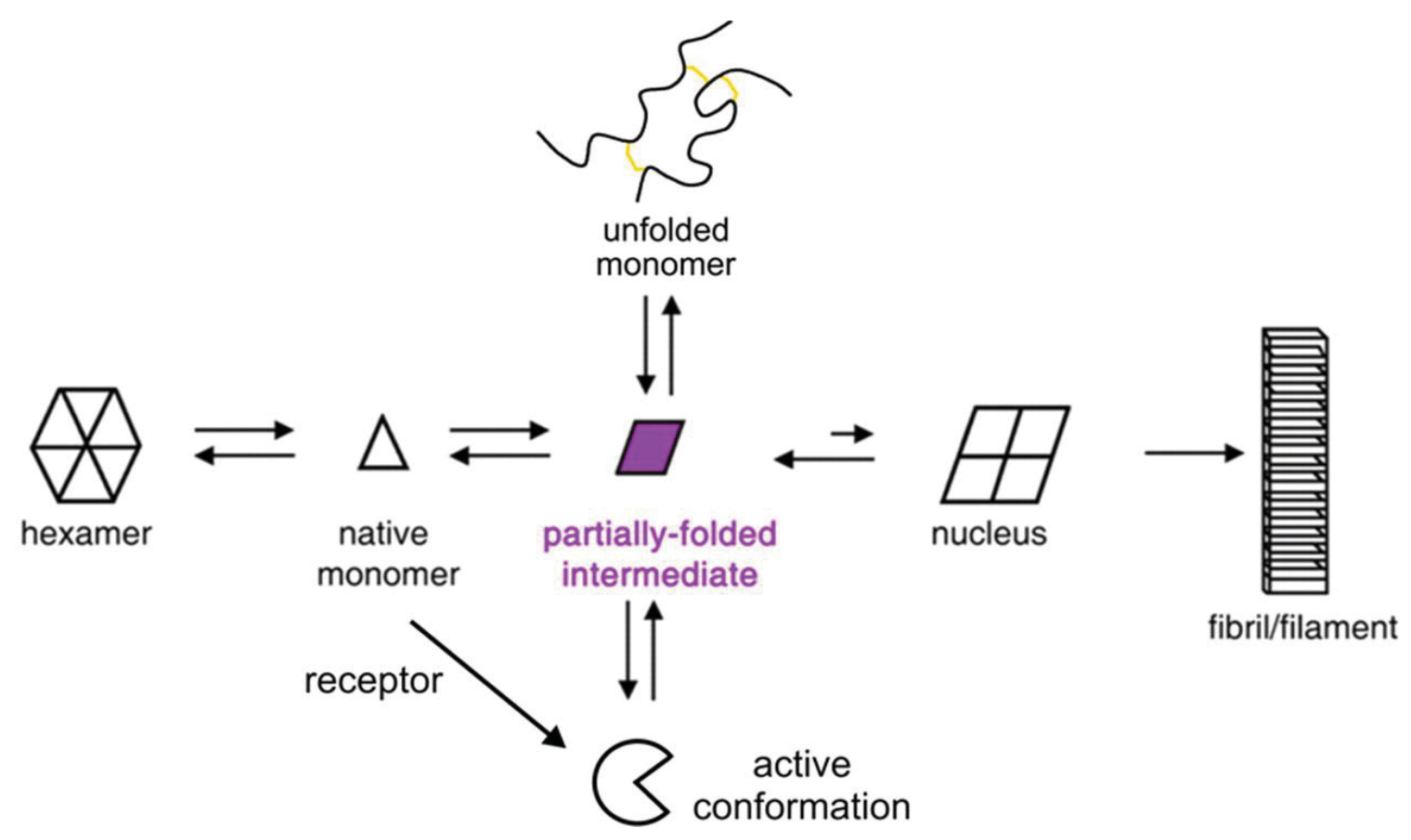

Figure 2-4. Mechanism of insulin fibrillation in monomeric form

Pathway of insulin fibril formation via partial unfolding of monomers leading to amyloidogenic nuclei and insulin fibril/filament.

Reprinted with permission. Yang, Y., Petkova, A., Huang, K., Xu, B., Hua, Q.X., Ye, I.J., Chu, Y.C., Hu, S.Q., Phillips, N.B., Whittaker, J. and Ismail-Beigi, F. (2010). An Achilles' Heel in an Amyloidogenic Protein and Its Repair INSULIN FIBRILLATION AND THERAPEUTIC DESIGN. Journal of Biological Chemistry, 285(14), 1080610821. 
Insulin delivery is vial and syringes. Although it is the most cost-effective option, there are several disadvantages in this method such as needle phobia of the patients, infection and sickness associated with multiple use of needles, use of incorrect insulin product and inaccurate dose administration [85]. Therefore, this method is becoming less popular among patients and doctors. Insulin pens are gaining preference in this respect owing to their advantage of dose accuracy, reusability and safety features. But they are associated with higher cost in comparison with vials and syringes. In several studies, insulin pens were found to be more accurate than syringes in measuring low insulin dose especially less than 5 units as well as socially more acceptable [85-87]. However, insulin pens are also associated with skin penetration, although to a lesser extent compared to vial and syringe method. Therefore, jet injectors have been developed to deliver insulin without skin penetration. Jet injector uses high pressure narrow jet of liquid insulin formulation instead of needle to penetrate the skin. In diabetic patients, insulin jet injectors showed increased insulin absorption and significant decrease in plasma glucose level compared to insulin pens $[88,89]$. Insulin delivered via jet injectors also showed PK profile more close to endogenous insulin and significant improvement in post-prandial glucose control compared to pens in diabetes patients [90]. However, physiologically relevant insulin delivery requires to mimic the pattern of natural insulin secretion from pancreas. Insulin pump therapy can serve this purpose by providing continuous supply of insulin at variable rate in response to the alteration in blood glucose level. In clinical trials, insulin pump therapy showed significant glucose lowering effect, long-term glycemic control and reduction in insulin dose compared to conventional multiple daily injections [91, 92]. Yet, higher cost, inconvenience of constantly wearing it and training requirement limit the broad use of insulin pump among diabetes patients. 


\section{CHAPTER 3. INJECTABLE DELIVERY SYSTEMS FOR INSULIN}

The concept of using drug delivery systems to prolong the action-time profile of insulin was first materialized by Parkes and Young in 1939 [93]. They implanted solid tablets made of insulin powder in the subcutaneous space in rabbits but unfortunately, it showed slight prolongation of duration of action of insulin compared to regular insulin injection. This unsuccessful attempt led to the use of polyacrylamide slurry for sustained delivery of insulin [94]. Subcutaneous injection of insulin loaded polyacrylamide slurry maintained the growth of diabetic rats at a normal rate until the removal of the implant after 21 days. However, polyacrylamide causes irritation in animal tissues due to its inflammatory nature and therefore, non-inflammatory vinyl acetate-ethylene copolymer was synthesized to develop sustained release implant of insulin [95]. Insulin loaded vinyl acetate-ethylene copolymer disc was implanted subcutaneously in streptozotocin induced diabetic rats. Insulin was released for 29 days in biologically active form and consequently, maintained normoglycemia as well as normal weight gain. Vinyl-acetateethylene copolymer was non-inflammatory in nature but the need for surgical implantation and removal of the implant was inconvenient. As a consequence, biodegradable and injectable liposomal system was developed with egg lecithin which resolved the issues related to surgical procedure and inflammation [96]. But the glucose lowering effect was observed only for little more than 7 hours, although a small response still remained $24 \mathrm{~h}$ after injection. To extend the release of insulin with biodegradable systems, albumin microbeads were prepared which showed sustained release of insulin for more than two weeks after subcutaneous implantation [97, 98]. Although albumin microbeads demonstrated sustained insulin release and eliminated the need of surgical removal of implant, the surgical implantation still remained an issue which was finally resolved by the use of polylactic acid (PLA) based microcapsules [99, 100]. Insulin loaded PLA microcapsules maintained normoglycemia for five days in diabetic rats. This was the earliest example of a biodegradable injectable system for sustained delivery of insulin. In the next few decades, the use of poly lactic acid and polyglycolic acid (PLGA) based polymers gave rise to the development of numerous sustained release systems. As a consequence, complex dosage forms such as microspheres, nanoparticles, in situ forming depots, and composite systems have emerged as novel delivery technologies for sustained release of insulin (Figure 3-1). This chapter will give a brief overview of each of the systems along with their advantages and limitations.

\section{Microspheres}

Microspheres are spherical particles with a size range of 1-1000 $\mu \mathrm{m}$ and are usually prepared from natural or synthetic polymers. In the last few decades, microsphere based delivery systems have been extensively investigated for sustained release of protein and peptide drugs $[101,102]$. Microspheres have been shown to release drugs over a long time spanning from days to months [102-104]. Starting in the late 90s, the concept of using biodegradable polymers to develop sustained release microspheres for insulin was pioneered by Lin et al. by emulsification-solvent evaporation method [99, 100]. The 

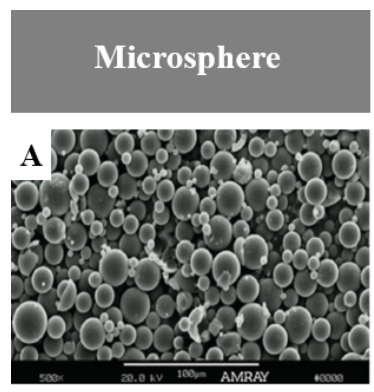

3-5 $\mu \mathrm{m}$ to $<100 \mu \mathrm{m}$ spherical particles

- w/o/w double emulsion solvent evaporation method most commonly used fabrication technique

- PLGA (5-75 kD) most commonly used polymer for microsphere fabrication

- PLA and PCL, less commonly used polymers

- 7-60 days in vivo release

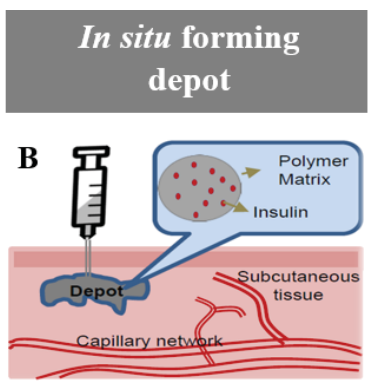

- Thermo-responsive or phase inversion based system

- PLGA, PLA and PEG based copolymer for thermo-responsive system

- Mostly PLGA for phase inversion based system

- $15-30 \%$ polymer concentration

- 3-70 days in vivo release
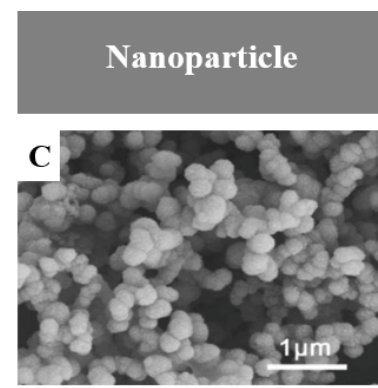

- Nano sized spherical particles

- "Proof-of-concept" level study

- Enzyme-loaded and glucose-responsive nanoparticles

- $\quad<10$ days in vivo release
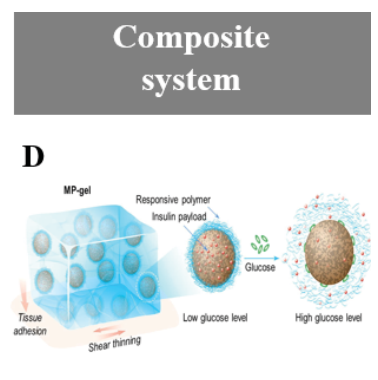

- Two-in-one delivery system

- nanoparticle-inmicrosphere/hydrogel or microsphere-in-hydrogel based system

- Reduced initial burst or particle migration after injection

- 1-2 weeks in vivo release

Figure 3-1. Summary findings and representative images of sustained release delivery systems for insulin investigated in preclinical studies

A: SEM image of insulin loaded salicylic acid-poly(anhydride ester) microspheres. The scale bar represents $100 \mu \mathrm{m}$.

B: Illustration of insulin loaded in situ forming depot.

C: SEM image of insulin nanoparticles. The scale bar represents $1000 \mathrm{~nm}$.

D: Illustration of insulin loaded microsphere-hydrogel composite system.

Permissions:

A: Adapted with permission. Yu, W., Bien-Aime, S., Li, J., Zhang, L., McCormack, E.S., Goldberg, I.D., Narayan, P. and Uhrich, K.E. (2015). Injectable microspheres for extended delivery of bioactive insulin and salicylic acid. Journal of Bioactive and Compatible Polymers, 30(3), 340-346.

C: Adapted with open access permission. Xiao, Y., Wang, X., Wang, B., Liu, X., Xu, X., \& Tang, R. (2017). Long-term effect of biomineralized insulin nanoparticles on type 2 diabetes treatment. Theranostics, 7(17), 4301.

D: Reprinted from Acta biomaterialia, 64, Zhao, F., Wu, D., Yao, D., Guo, R., Wang, W., Dong, A., Kong, D. and Zhang, J., An injectable particle-hydrogel hybrid system for glucose-regulatory insulin delivery, 334-345, 2017, with permission from Elsevier. 
study demonstrated that microspheres prepared from $30 \mathrm{kD}$ poly lactic acid could maintain normoglycemia in diabetic SD rats for 5 days [99]. Coating with ethyl vinyl acetate or wax further prolonged insulin release and maintained normoglycemia for 2 weeks [100]. Since then, numerous injectable microspheres prepared from biodegradable polymers have been investigated for controlled release of insulin. Although numerous biodegradable and biocompatible polymers of natural and synthetic origin were used to produce microspheres for proteins and peptides, the use of polymers to develop microsphere formulations for insulin has been mostly limited to poly(lactic-co-glycolic acid) (PLGA) $[105,106]$ and polylactic acid (PLA) $[107,108]$. Table 3-1 provides examples of microsphere formulations used in preclinical studies for sustained delivery of insulin.

An ideal microsphere should have high API encapsulation efficiency and provide conformational stability and sustained release of the encapsulated protein along with optimum particle size and size distribution for easy injectability and low initial burst $[101,109]$. The rate and extent of drug release from microspheres largely depend on all of these factors which, in turn, depend on the composition and fabrication techniques of microspheres. Insulin containing microspheres are usually prepared by water/oil/water (w/o/w) double emulsion-solvent evaporation method and also, to a lesser extent, variation of w/o/w method such as solid/oil/water (s/o/w) $[110,111]$ and solid/oil/oil (s/o/o) [112]. Insulin microspheres are also prepared by spray drying process [113]. Because of its simple process, robust control on process parameters and inexpensive instrumentation, w/o/w double emulsion-solvent evaporation method is most widely used in this regard [109]. In this method, aqueous insulin is first dispersed in a polymer containing organic solvent to form a w/o emulsion which is called primary emulsion. The primary emulsion is then dispersed into large volume of water (which contains emulsifier) to obtain w/o/w emulsion. In the final step, the organic solvent is evaporated in reduced pressure. This method resulted in relatively small size of insulin containing microspheres ranging from 3-5 $\mu \mathrm{m}$ up to less than $100 \mu \mathrm{m}[108,114,115]$.

However, protein denaturation during microsphere preparation is a major concern in traditional w/o/w method because removal of large volume of water during secondary emulsification step often leads to protein denaturation at the water/solvent surface, low loading efficiency and wide size distribution [116, 117]. To resolve this issue, zinc has been used as insulin stabilizing agents during microsphere preparation. Manoharan et al. demonstrated that the addition of zinc during the primary emulsification step (w/o) increased the physical stability of insulin [118]. In this study, addition of zinc not only stabilized insulin in the microspheres, it also increased the encapsulation efficiency and decreased initial burst release. As a result, insulin was released from the microspheres for more than two weeks [119]. Similarly, addition of cationic polyelectrolyte, poly(ethylene glycol)-b-poly(L-histidine) diblock copolymer (PEG-polyHis), was also shown to decrease the aggregation of insulin at the aqueous/organic interface during microencapsulation process and preserved insulin stability during primary emulsification step [120].

The stability of insulin can also be preserved following s/o/w fabrication method 
Table 3-1. Examples of microsphere formulations used in preclinical studies for sustained delivery of insulin

\begin{tabular}{|c|c|c|c|c|c|}
\hline $\begin{array}{l}\text { Fabrication } \\
\text { Techniques }\end{array}$ & $\begin{array}{l}\text { Polymer, } \\
\text { Molecular } \\
\text { Weight }\end{array}$ & Size & Animal Model & Key Findings & Ref. \\
\hline $\begin{array}{l}\text { s/o/w emulsion- } \\
\text { solvent } \\
\text { evaporation }\end{array}$ & $\begin{array}{l}\text { PLGA (50:50), } \\
6600 \mathrm{Da}\end{array}$ & $\begin{array}{l}15-30 \\
\mu \mathrm{m}\end{array}$ & $\begin{array}{l}\text { STZ-induced } \\
\text { diabetic male } \\
\text { Wister rats }\end{array}$ & $\begin{array}{l}\text { low initial burst and } \\
\text { sustained insulin release } \\
\text { for } 2 \text { weeks. }\end{array}$ & [121] \\
\hline $\begin{array}{l}\text { w/o/w double } \\
\text { emulsion-solvent } \\
\text { evaporation }\end{array}$ & $\begin{array}{l}\mathrm{p}(\mathrm{CPH} / \mathrm{SA}) \\
(40: 60,50: 50), \\
24000 \mathrm{Da}, \\
16000 \mathrm{Da}\end{array}$ & $\sim 40 \mu \mathrm{m}$ & $\begin{array}{l}\text { STZ-induced } \\
\text { diabetic male } \\
\text { Sprague-Dawley } \\
\text { rats }\end{array}$ & $\begin{array}{l}\text { Sustained insulin } \\
\text { release for more than } 40 \\
\text { days. }\end{array}$ & [115] \\
\hline $\begin{array}{l}\text { w/o/w double } \\
\text { emulsion- and } \\
\text { s/o/w emulsion- } \\
\text { solvent } \\
\text { evaporation }\end{array}$ & PLGA $(50: 50)$ & $\begin{array}{l}\mathrm{w} / \mathrm{o} / \mathrm{w}: \\
55 \mu \mathrm{m} \\
\mathrm{s} / \mathrm{o} / \mathrm{w}: 20 \\
\mu \mathrm{m}\end{array}$ & $\begin{array}{l}\text { Alloxan-induced } \\
\text { New Zealand } \\
\text { White rabbits }\end{array}$ & $\begin{array}{l}\text { Sustained insulin } \\
\text { release up to } 40 \text { days } \\
\text { and showed } \\
\text { biocompatibility in } 12 \\
\text { weeks study. }\end{array}$ & [122] \\
\hline $\begin{array}{l}\text { w/o/w double } \\
\text { emulsion-solvent } \\
\text { evaporation }\end{array}$ & $\begin{array}{l}\mathrm{p}(\mathrm{CPP}: \mathrm{SA}) \\
(50: 50), 21000 \\
\mathrm{Da}\end{array}$ & $\begin{array}{l}41.5 \text { to } \\
49.8 \mu \mathrm{m}\end{array}$ & $\begin{array}{l}\text { STZ-induced } \\
\text { diabetic male } \\
\text { Sprague-Dawley } \\
\text { rats }\end{array}$ & $\begin{array}{l}\text { Controlled release of } \\
\text { insulin for } 35 \text { days. }\end{array}$ & [123] \\
\hline $\begin{array}{l}\text { w/o/w double } \\
\text { emulsion-solvent } \\
\text { evaporation }\end{array}$ & $\begin{array}{l}\text { PLGA }(85: 15) \text {, } \\
\text { MW 50000- } \\
75000 \mathrm{Da}\end{array}$ & $14-15 \mu \mathrm{m}$ & $\begin{array}{l}\text { STZ-induced } \\
\text { diabetic male } \\
\text { Sprague-Dawley } \\
\text { rats }\end{array}$ & $\begin{array}{l}\text { Multi-arm histidine } \\
\text { copolymer loaded } \\
\text { microspheres } \\
\text { maintained } \\
\text { normoglycemic effect } \\
\text { for } 4 \text { weeks. }\end{array}$ & [114] \\
\hline $\begin{array}{l}\text { w/o/w double } \\
\text { emulsion-solvent } \\
\text { evaporation }\end{array}$ & $\begin{array}{l}\text { PLGA (50:50) } \\
\text { and PLA, MW } \\
45000 \mathrm{Da}\end{array}$ & $36-37 \mu \mathrm{m}$ & $\begin{array}{l}\text { Alloxan induced } \\
\text { diabetic female } \\
\text { Wister rats }\end{array}$ & $\begin{array}{l}\text { Glucose lowering effect } \\
\text { maintained for } 1 \text { week. }\end{array}$ & [107] \\
\hline $\begin{array}{l}\text { w/o/w double } \\
\text { emulsion-solvent } \\
\text { evaporation }\end{array}$ & $\begin{array}{l}\text { PLA, } 21400 \\
\text { Da and } \\
\text { PEG, } 2000 \mathrm{Da}\end{array}$ & $3-5 \mu \mathrm{m}$ & $\begin{array}{l}\text { STZ-induced } \\
\text { diabetic female } \\
\text { Sprague-Dawley } \\
\text { rats }\end{array}$ & $\begin{array}{l}\text { Sustained insulin } \\
\text { release for } 1 \text { week. }\end{array}$ & [108] \\
\hline $\begin{array}{l}\text { w/o/w double } \\
\text { emulsion-solvent } \\
\text { evaporation }\end{array}$ & $\begin{array}{l}\text { PLGA (50:50), } \\
\text { MW 38000- } \\
54000 \mathrm{Da}\end{array}$ & $\begin{array}{l}5.9 \pm 0.5 \\
\mu \mathrm{m}\end{array}$ & $\begin{array}{l}\text { STZ-induced } \\
\text { diabetic male } \\
\text { Wister rats }\end{array}$ & $\begin{array}{l}\text { Sustained insulin } \\
\text { release for } 21 \text { days. }\end{array}$ & [124] \\
\hline $\begin{array}{l}\text { s/o/w emulsion- } \\
\text { solvent } \\
\text { evaporation }\end{array}$ & $\begin{array}{l}\text { PLGA (50:50), } \\
\text { MW } 5800 \mathrm{Da}\end{array}$ & $\begin{array}{l}\text { Not } \\
\text { Available }\end{array}$ & $\begin{array}{l}\text { Diabetes prone } \\
\text { BB/Wor//Tky rats }\end{array}$ & $\begin{array}{l}\text { Normoglycemia } \\
\text { maintained after } \\
\text { subcutaneous injection } \\
\text { in every } 10 \text { days. }\end{array}$ & [125] \\
\hline $\begin{array}{l}\text { w/o/w double } \\
\text { emulsion-solvent } \\
\text { evaporation }\end{array}$ & $\begin{array}{l}\text { PCL, } 72000 \\
\mathrm{Da}\end{array}$ & $37-52 \mu \mathrm{m}$ & $\begin{array}{l}\text { STZ-induced } \\
\text { male Wister rats }\end{array}$ & $\begin{array}{l}\text { Maintained } \\
\text { normoglycemia up to } 60 \\
\text { days. }\end{array}$ & [126] \\
\hline $\begin{array}{l}\text { s/o/w emulsion- } \\
\text { solvent } \\
\text { evaporation }\end{array}$ & $\begin{array}{l}\text { PLGA (50:50), } \\
\text { MW } 6000 \mathrm{Da}\end{array}$ & $\begin{array}{l}0.3-0.5 \\
\mu \mathrm{m}\end{array}$ & $\begin{array}{l}\text { STZ-induce male } \\
\text { Wister rats }\end{array}$ & $\begin{array}{l}\text { Normoglycemia } \\
\text { maintained from } 7^{\text {th }} \text { day } \\
\text { to } 10^{\text {th }} \text { day after } \\
\text { injection. }\end{array}$ & [127] \\
\hline $\begin{array}{l}\text { w/o/w double } \\
\text { emulsion-solvent } \\
\text { evaporation }\end{array}$ & $\begin{array}{l}\text { PLGA (50:50), } \\
\text { MW 12000 Da }\end{array}$ & $\begin{array}{l}\text { Not } \\
\text { available }\end{array}$ & $\begin{array}{l}\text { STZ-induced } \\
\text { diabetic Kunming } \\
\text { mice }\end{array}$ & $\begin{array}{l}\text { Maintained } \\
\text { normoglycemia for } \\
\text { about } 16 \text { days. }\end{array}$ & [128] \\
\hline
\end{tabular}


a slight variation of traditional w/o/w method [129]. In this method, solid insulin particles are dispersed in the polymer solution to form s/o emulsion which is then introduced into large volume of aqueous solution that contains emulsifying agent. The addition of solid protein particle reduces the conformational mobility of insulin which is often observed in dissolved proteins and results in higher protein stability as well as higher encapsulation efficiency [109]. For example, Bao et al. fabricated PLGA microspheres by s/o/w process and insulin encapsulation was found to be more than $90 \%(\mathrm{w} / \mathrm{w})$ with an insulin loading efficiency of $15 \%(\mathrm{w} / \mathrm{w})$ [111]. The system also showed significantly lower initial burst compared to insulin containing microspheres prepared by w/o/w method.

Spray drying method is another method to prepare insulin loaded microspheres. The main advantages of this method are easy process control and convenience in scale-up $[130,131]$. In this method, protein solution or emulsion (w/o or s/o) is atomized at an elevated temperature to evaporate the organic solvent $[109,132]$. The insulin containing microspheres prepared by spray drying method demonstrated lower initial burst and maintained its chemical and conformational stability [133]. Different excipients added during spray drying process are also found to modulate microsphere properties. For example, co-encapsulation of HP $\beta C D$ with inuslin in PLGA microspheres slowed down the insulin release rate and mainatined conformational stability of encapsulated and released insulin [133]. Similarly, insulin encapsulated with phospholipids such as glycerol monostearate and glycerol distearate in PLGA microsphere showed higher encapsulation efficiency of about $90 \%$ [113].

As mentioned, the high initial burst is a major problem in microsphere-based sustained release delivery systems because of uneven distribution of drug molecules and its porous surface which allow easy diffusion of encapsulated drugs [134, 135]. This problem is paramount especially for insulin where higher initial burst can cause severe hypoglycemia resulting in life-threatening situation. To address this problem, double walled PLGA microsphere was developed using water/oil/oil/water (w/o/o/w) emulsion solvent evaporation technique and compared with microspheres prepared by conventionl w/o/w method [106]. Double walled microspheres exhibited non-porous smooth surface, smaller particle size and significant reduction in initial burst compared to microspheres prepared in conventional way. The higher initial burst also depends on the nature of the polymer. The hydrophilic characteristics of polymer also affect the initial burst and overall release of insulin from the microspheres. For example, Presmanes et al. demonstrated that acid terminated PLGA microspheres (more hydrophilic) showed higher initial burst compared to ester terminated PLGA microspheres (which is less hydrophilic) [124]. As a result, ester terminated PLGA microspheres maintained hypoglycemic effect up to 4 weeks while acid terminated PLGA microspheres showed hypoglycemic effect for less than two weeks. Molecular weight of the polymers is another important factor affecting the size, encapsulation efficiency and drug release from the microsphere [136, 137]. High molecular weight PLGA microsphere (35813 Da) generated larger particle size compared to low molecular weight PLGA microspheres (6065 Da) but insulin encapsulation efficiency was found to be lower for high molecular weight microspheres [138]. High MW PLGA microsphere also demonstrated lower initial burst of insulin prolonged insulin release compared to low MW microspheres [138]. 
Several microsphere based sustained release systems have been developed for insulin which successfully demonstrated long-term normoglycemia ranging from days to months in preclinical studies. Table 3-1 summarizes such preclinical studies in which glucose lowering effect was observed for at least one week after injection of insulin loaded microspheres. It shows that that most of the microsphere formulations used in preclinical studies are prepared from poly lactic-co-glycolic acid. The molecular weight of PLGA used in these studies ranged from $5000 \mathrm{Da}$ to $75000 \mathrm{Da}$. These PLGA microspheres maintained sustained insulin release for up to five weeks where higher molecular weight microspheres showed longer release profile. The biocompatibility, customizable mechanical and degradation properties, tunable drug release kinetics via structural modification and most importantly, approval from FDA for parenteral administration has made PLGA an attractive polymer for developing controlled release parenteral formulations [139].

Therefore, PLGA based microspheres gained much attention and have been subject to considerable research which led to the approval of several PLGA based microsphere products in the last few years [140]. As a consequence, the first PLGA based insulin microsphere formulation (AB101) has been approved for Phase I first in human clinical trial as a once-weekly treatment for diabetes [141]. However, the formulation of AB101 is different than formulations investigated in preclinical studies. Low molecular weight (5 kD) PEG was first conjugated with B chain N-terminus of recombinant human insulin to facilitate the dissolution of insulin in oil or water based solution during emulsification step [142]. PEGylated insulin was then co-dissolved with PLGA in oil phase and finally uniform microspheres are obtained via o/w emulsion technique [142]. AB101 is formulated in single step emulsification method whereas the microspheres reported in preclinical studies (Table 4) were prepared in double emulsion method which is associated with scale-up production difficulties [109]. In AB101, PEGylation of insulin facilitates dissolution in oil phase which resulted in uniform distribution of insulin in the microspheres leading to predicted release kinetics observed in preclinical studies. On the other hand, the preclinical stage microspheres usually used human or bovine serum insulin suspended in water phase during first emulsification step of microsphere preparation which might lead to uneven distribution of insulin in the microspheres causing burst release and unpredictable release kinetics. In this respect, future development should consider use of long acting insulin analogues, PEGylated/lapidated insulin or coencapsulation of cationic polymers to obtain microspheres with less initial burst and more predictable long term release. Further investigations are also warranted to address the inherent issues of microsphere based technology such as poor in vitro-in vivo correlation, and scale-up production cost to take preclinical formulations into clinical stage [143-145].

\section{In situ Forming Depots}

Injectable in situ forming depots are low viscosity injectable polymeric solution or suspension which, upon injection, forms a semi-solid or solid polymeric matrix at the injection site [146-148]. The solidification of polymer occurs via different mechanisms 
such as photo cross-linking $[149,150]$ or $\mathrm{pH}$ change $[151,152]$, temperature [153] and solvent exchange $[148,154]$. The drug entrapped in the polymeric matrix is released in a sustained manner providing desired drug concentration in the systemic circulation for a prolonged time. The polymers used in this case are usually biodegradable in nature which undergo degradation over time and are eventually cleared from the body. In situ forming depots were developed as an alternative controlled release system to overcome some of the disadvantages of microspheres such as high fabrication cost, needle clogging, the need of reconstitution, and migration after injection [143-145]. Among different types of in situ forming depots, temperature-sensitive and phase-sensitive (solvent-exchange) systems have been primarily reported for sustained release of insulin.

\section{Thermosensitive In Situ Forming Depots}

Thermosensitive in situ forming depots refer to polymeric solution which undergoes solution to gel transition in response to the change in temperature. The temperature at which the phase transition occurs is called critical gelation temperature. Certain polymers are characterized by their lower critical gelation temperature (LCGT) and upper critical gelation temperature (UCGT) [146]. At LCGT, the polymeric solutions remain in solution state with lower viscosity but undergo gelation when the temperature goes above LCGT. When the temperature again starts to approach UCGT, the gel structure starts to rupture and is transformed into solution again. Polymers used to develop thermosensitive in situ forming depots usually have their LCGT between room and physiological temperature $\left(37^{\circ} \mathrm{C}\right)$ and therefore, they are liquid in room temperature and becomes solidified when injected into the body [155].

Various thermosensitive in situ forming depots have been designed as controlled release carrier for insulin $[101,156]$. The polymers used in this purpose are usually thermosensitive block polymers which are either non-ionic co-polymers, cationic polymers or less commonly polypeptides. Poloxamers, Poly (ethylene oxide)/poly (propylene oxide)/poly (ethylene oxide) (PEO-PPO-PEO), are the first class of thermosensitive block polymers approved by FDA. They are non-ionic in nature and demonstrate sol-gel transition at body temperature at $15 \%(\mathrm{w} / \mathrm{w})$ concentration and above [146]. Due to their safety profile and good biocompatibility, poloxamer based in situ forming gel systems have been explored for sustained insulin delivery $[157,158]$. For example, Yang et al. developed a sustained release delivery system using Poloxamer 407 (P407) and Poloxamer 188 (P188) [159]. To improve the mechanical properties, hydroxypropyl methyl cellulose (HPMC) was added to the system. Insulin microcrystal loaded Poloxamer/HPMC (P188:P407:HPMC = 9:20:3 \%w/v) formulation demonstrated hypoglycemic effect in diabetic SD rats for 3 days.

Attempts have also been made to deliver insulin with commercially available thermosensitive non-ionic polymer such as ReGel ${ }^{\circledR}$ (PLGA-PEG-PLGA) which is on its way towards FDA approval [160]. Kim et al. developed an injectable sustained release formulation for insulin using $\operatorname{ReGel}^{\circledR}$ [161]. The formulation was composed of $23 \mathrm{wt} \%$ copolymer solution with $0.2 \%$ zinc and $5.04 \mathrm{mg} / \mathrm{ml}$ insulin loaded formulation achieved 
sustained insulin release up to 15 days after a single subcutaneous injection in SpragueDawley (SD) rats. The same research group also studied the effect of this formulation on Zucker Diabetic Fatty (ZDF) rat model [162]. In this study, the formulation was developed with $6 \mathrm{mg} / \mathrm{ml}$ insulin in $23 \mathrm{wt} \%$ copolymer solution with $10 \mathrm{wt} \%$ zinc carbonate. A single subcutaneous injection of this formulation maintained steady state plasma levels of exogenous insulin for almost 2 weeks in type 2 diabetic ZDF rat model and consequently, maintained normoglycemia during this period. Similarly. Tahami et al. developed triblock copolymer with PLA and PEG by varying the PLA chain length and insulin (at a dose of $90 \mathrm{U} / \mathrm{kg}$ body weight) containing PLA-PEG-PLA copolymer solution $(40 \% \mathrm{w} / \mathrm{w})$ demonstrated continuous insulin release over a period of 3 months and maintained blood glucose level of diabetic male Sprague-Dawley (SD) rats below 200 $\mathrm{mg} / \mathrm{dL}$ [163]. Moreover, copolymer with higher PLA content showed lower insulin release rate and longer duration of action because higher PLA content introduced more hydrophobicity into the system. Although the delivery system released insulin for several months, the conformational stability and secondary structure was partially reduced. To increase the stability of insulin, Oak et al. used chitosan-zinc-insulin complex and loaded into the previously mentioned PLA-PEG-PLA formulation [153]. Positively charged chitosan was used to stabilize zinc-insulin hexamer in order to reduce the initial burst (Figure 3-2). Chitosan-zinc-insulin complex significantly reduced the initial burst release of insulin when compared with the release in the absence of chitosan and zinc [163]. The delivery system composed of $30 \%(\mathrm{w} / \mathrm{w})$ copolymer solution released insulin in biologically active form and maintained normoglycemic level in diabetic SD rats for 70 days. Moreover, the delivery system did not produce any inflammation during the study period and insulin, both released and extracted from the implant, was conformationally stable.

Apart from PLGA and PLA based non-ionic block co-polymers, poly $(\varepsilon-$ caprolactone) (PCL) was also used as a component to synthesize temperature sensitive block co-polymer for controlled delivery of insulin [164]. Huynh et al. developed 5 $\mathrm{mg} / \mathrm{ml}$ insulin containing PCL-PEG-PCL (25 wt\%) formulation which released insulin for 4 days in diabetic SD rats after a single subcutaneous injection. However, the formulation demonstrated high initial burst (>3500 mU/L) compared to free insulin $(<1000 \mathrm{mU} / \mathrm{L})$ which was assumed to be caused by slow in vivo sol-gel transition of the formulation after injection. This problem was resolved by adding cationic poly $(\beta$-amino ester) which has been described later in this section.

The use of thermosensitive cationic polymers such as chitosan [165], poly $(\beta-$ amino ester) [166], poly(amidoamine) [167], poly(ethylene imine) [168], and poly(lysine) [169] is another interesting strategy for the delivery of genes and protein molecules because of their ability to bind anionic biomacromolecules. Insulin is negatively charged in physiological $\mathrm{pH}$ and therefore, cationic polymers can provide stability in insulin when mixed together. For example, Tahrir et al. used chitosan $/ \beta$-glycerol phosphate $(\mathrm{CS} / \beta$ Gp) co-polymer as a cationic delivery system for sustained insulin delivery [170]. The system released 19\% - 63\% insulin in vitro for more than 6 days depending on the amount of $\beta-\mathrm{Gp}$ in the system and the released insulin maintained its structural stability during this time. A single subcutaneous injection of CS $(2 \% \mathrm{w} / \mathrm{v}) / \beta-\mathrm{Gp}(8 \% \mathrm{w} / \mathrm{v})$ 


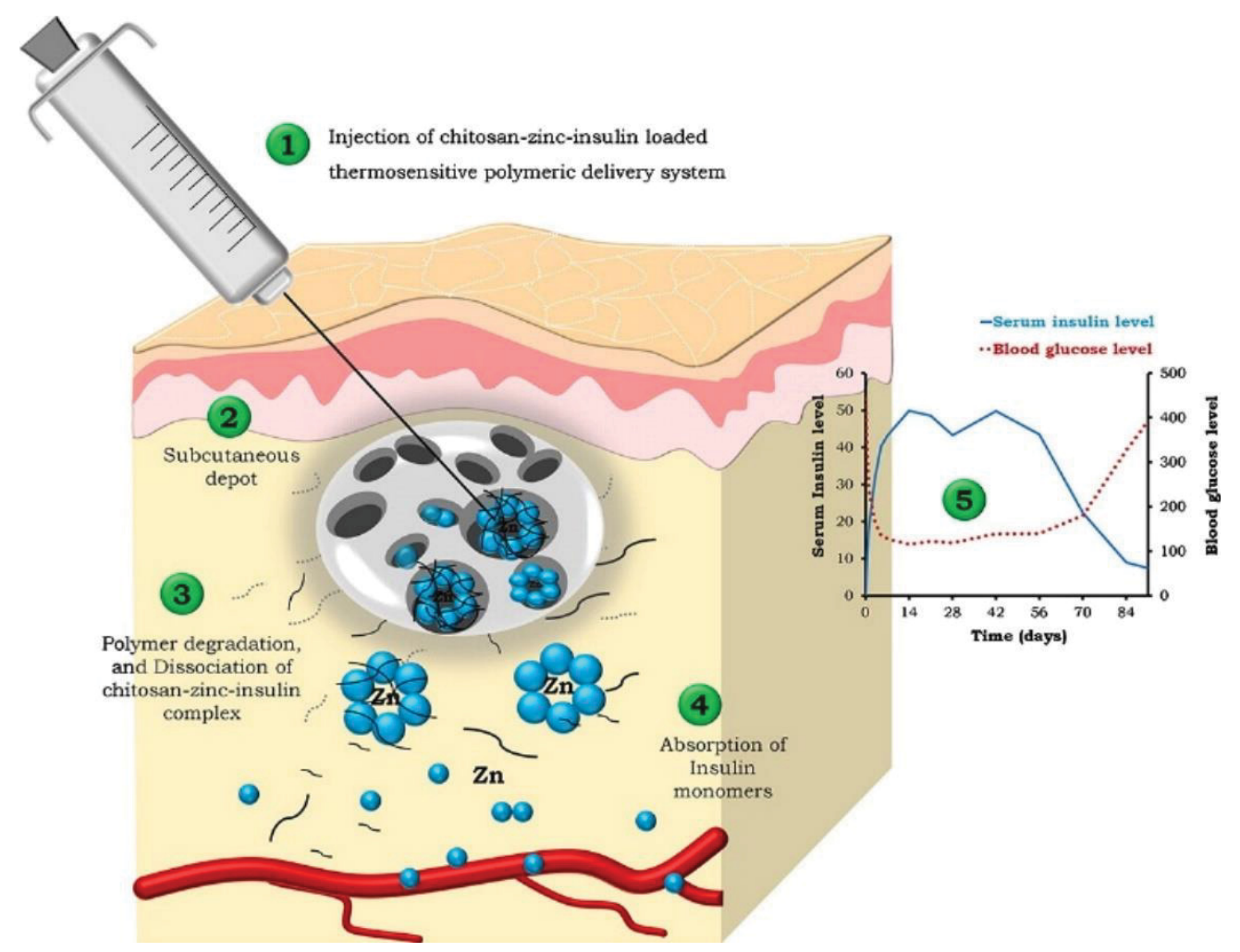

Figure 3-2. Chitosan-zinc-insulin loaded thermo-sensitive non-ionic in situ forming depot

The thermo-responsive gel forms depot after subcutaneous injection. Degradation of polymer as well as dissociation of insulin from chitosan-zinc-insulin complex prolongs the duration of action of insulin.

Reprinted from Journal of controlled release, 163(2), Oak, M., \& Singh, J., Chitosanzinc-insulin complex incorporated thermosensitive polymer for controlled delivery of basal insulin in vivo, 145-153, 2012, with permission from Elsevier. 
formulation encapsulated with $0.01 \mathrm{mg} / \mathrm{ml}$ insulin into diabetic $B a l b / c$ mice demonstrated glucose lowering effect for 5 days which was significantly longer than that of free insulin solution which only lasted for only several hours. Cationic polymers can also be used to synthesize dual-stimuli-responsive system such as both $\mathrm{pH}$ - and temperature-sensitive system. For example, thermosensitive oligo(amidoamine/ $\beta$-amino ester) (OAAAE) was synthesized as a cationic copolymer for controlled insulin release [171]. At low $\mathrm{pH}$ such as $\mathrm{pH} 6.6$, the copolymer remained in its solution state in a wide range of temperature $(0$ $-70^{\circ} \mathrm{C}$ ) but converted into gel in higher $\mathrm{pH}$ such as $\mathrm{pH} 7.4$ (Figure 3-3). Subcutaneously injected insulin $(5 \mathrm{mg} / \mathrm{ml})$ loaded OAAAE solution $(20 \mathrm{wt} \%)$ maintained the insulin level for 5 days in diabetic SD rats.

Similarly, Huynh et al. demonstrated that addition of positively charged poly( $\beta$ amino ester) (PAE) can also significantly increase the release duration of insulin from thermosensitive triblock copolymer PCL-PEG-PCL [164, 172]. To resolve the issue of higher initial burst of PCL-PEG-PCL system mentioned earlier in this section, they modified the triblock copolymer (PCL-PEG-PCL) by the addition of PAE into a pentablock copolymer PAE-PCL-PEG-PCL-PAE. Addition of positively charged PAE stabilized insulin by forming ionic bond with negatively charged insulin and also conferred $\mathrm{pH}$ responsiveness into the system. At $\mathrm{pH} 3-4$, the pentablock copolymer was dissolved in DI water and remained in solution state but formed gel at physiological temperature and $\mathrm{pH}$ upon subcutaneous injection (Figure 3-4). The hydrogel significantly reduced the initial burst of insulin and $10 \mathrm{mg} / \mathrm{ml}$ insulin loaded copolymer solution $(30 \mathrm{wt} \%)$ maintained a steady-state blood glucose level for more than 10 days [172]. This is an interesting example of how temperature sensitive systems can be tailored to obtain desired release profile.

Thermoresponsive sustained release systems has also been developed with polypeptides. One such system was reported by Jeong et al. where synthesized poly (ethylene glycol)-block-poly(alanine-co-phenyl alanine) (PEG-PAF) aqueous solution showed solution to gel transition at $37^{\circ} \mathrm{C}$ in a few seconds at a concentration as low as 3$7 \mathrm{wt} \%$ [173]. Insulin was loaded to $4 \mathrm{wt} \%$ PEG-PAF aqueous solution at a dose of 13.8 $\mathrm{mg} / \mathrm{kg} / \mathrm{rat}$. A single injection of $0.5 \mathrm{ml}$ formulation showed a glucose lowering effect over 18 days in diabetic rats.

\section{Phase Inversion Based In Situ Forming Depots}

Phase inversion based in situ forming depots are prepared by dissolving biodegradable and biocompatible polymer in a water-miscible and biocompatible organic solvent and the drug is dissolved or suspended in the polymeric solution [147]. Upon injection, the organic solvent is diffused out and the polymer precipitates forming a depot in the subcutaneous space (Figure 3-5). The drug remains in the depot and is released in a sustained manner via diffusion and erosion of the polymeric depot. Dunn et al. first proposed this system in 1990 by incorporating biodegradable polyesters such as PLA and PLGA in water miscible organic solvents such as N-methyl-2-pyrrolidone (NMP) and dimethyl sulfoxide [137, 154]. Since then, different phase inversion based in situ forming 


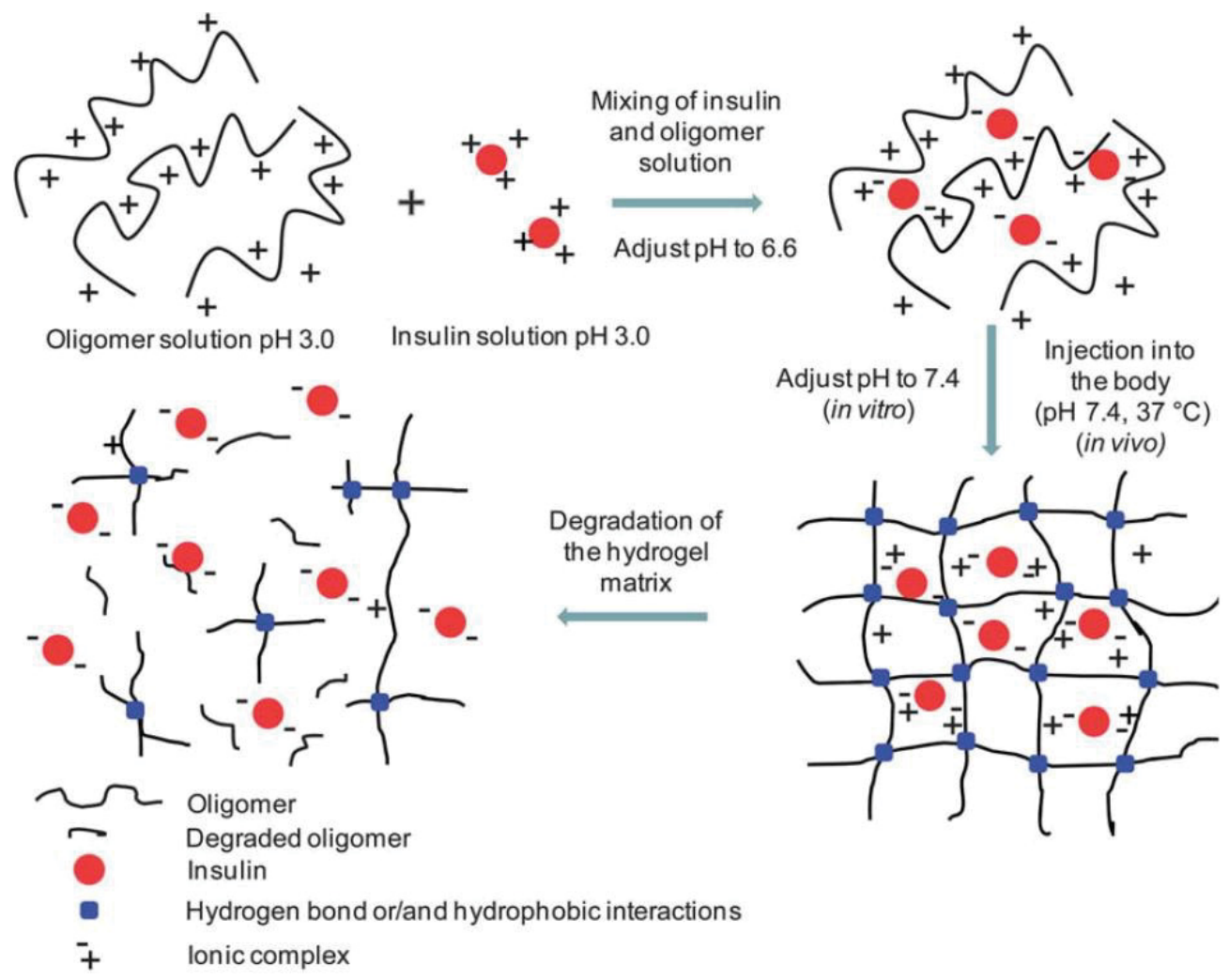

Figure 3-3. Insulin loaded thermo-sensitive cationic in situ forming depot Positively charged oligo(amidoamine/ $\beta$-amino ester) oligomers undergo gelation via hydrogel bonds and hydrophobic interaction and entrap negatively charged insulin in physiological $\mathrm{pH}$ and temperature after subcutaneous injection. Degradation of the oligomer matrix slowly release insulin from the polymer depot at the injection site. Reprinted with permission. Nguyen, M. K., Huynh, C. T., Gao, G. H., Kim, J. H., Chae, S. Y., Lee, K. C., \& Lee, D. S. (2011). Biodegradable oligo (amidoamine/ $\beta$-amino ester) hydrogels for controlled insulin delivery. Soft Matter, 7(6), 2994-3001. 
A

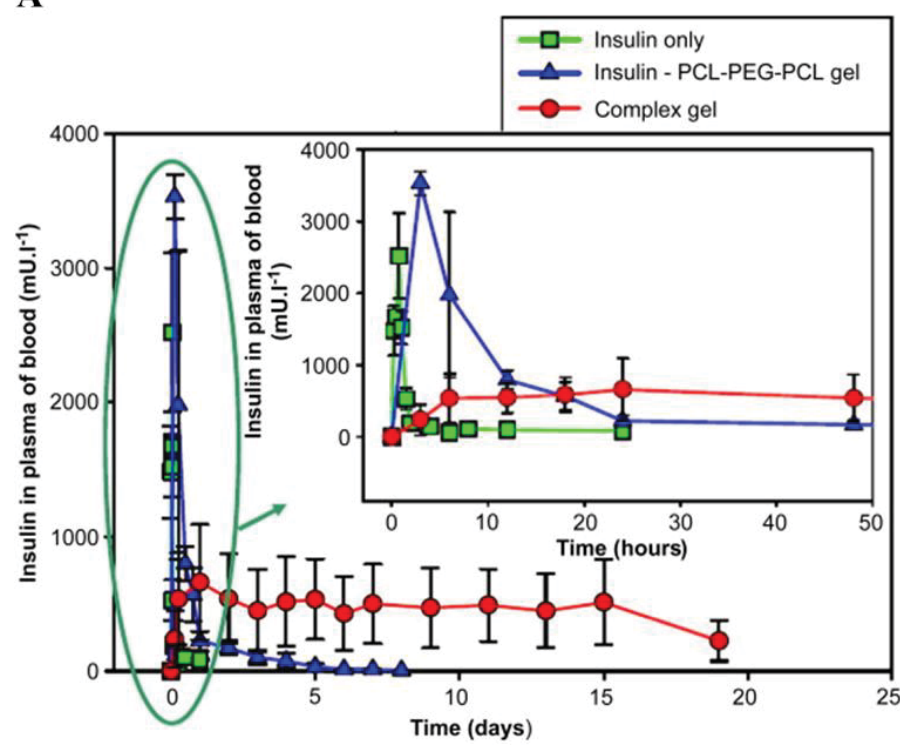

B

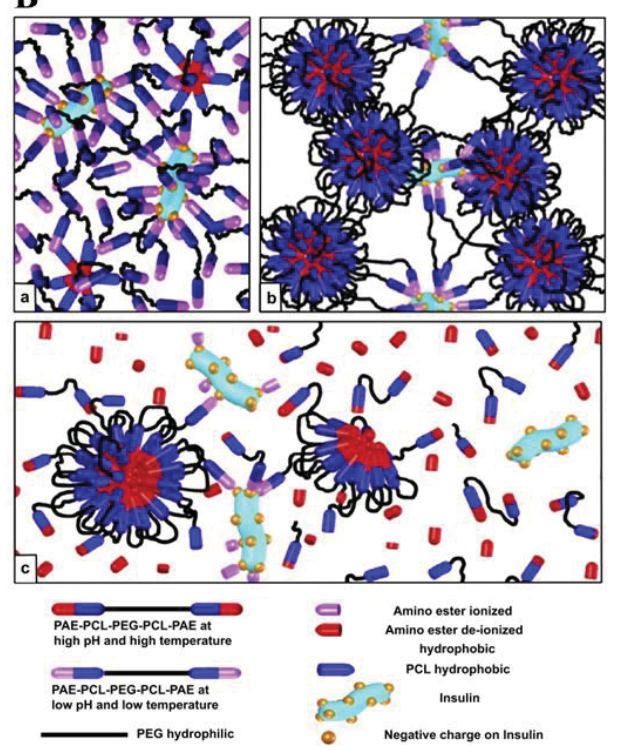

Figure 3-4. Thermo-sensitive pentablock co-polymer based cationic in situ forming depot

A) PAE-PCL-PEG-PCL-PAE (complex gel) demonstrated no initial burst and maintains steady state plasma insulin level for two weeks. B) Mechanism of insulin release from complex gel: (a) the polymer solution at low temperature and $\mathrm{pH}$ forms ionic complex with insulin, (b) gel formation at physiological $\mathrm{pH}$ and temperature results, (c) slow degradation of polymer releases insulin in sustained manner.

Adapted from Biomaterials, 29(16), Huynh, D.P., Nguyen, M.K., Pi, B.S., Kim, M.S., Chae, S.Y., Lee, K.C., Kim, B.S., Kim, S.W. and Lee, D.S., Functionalized injectable hydrogels for controlled insulin delivery, 2527-2534, 2008, with permission from Elsevier. 


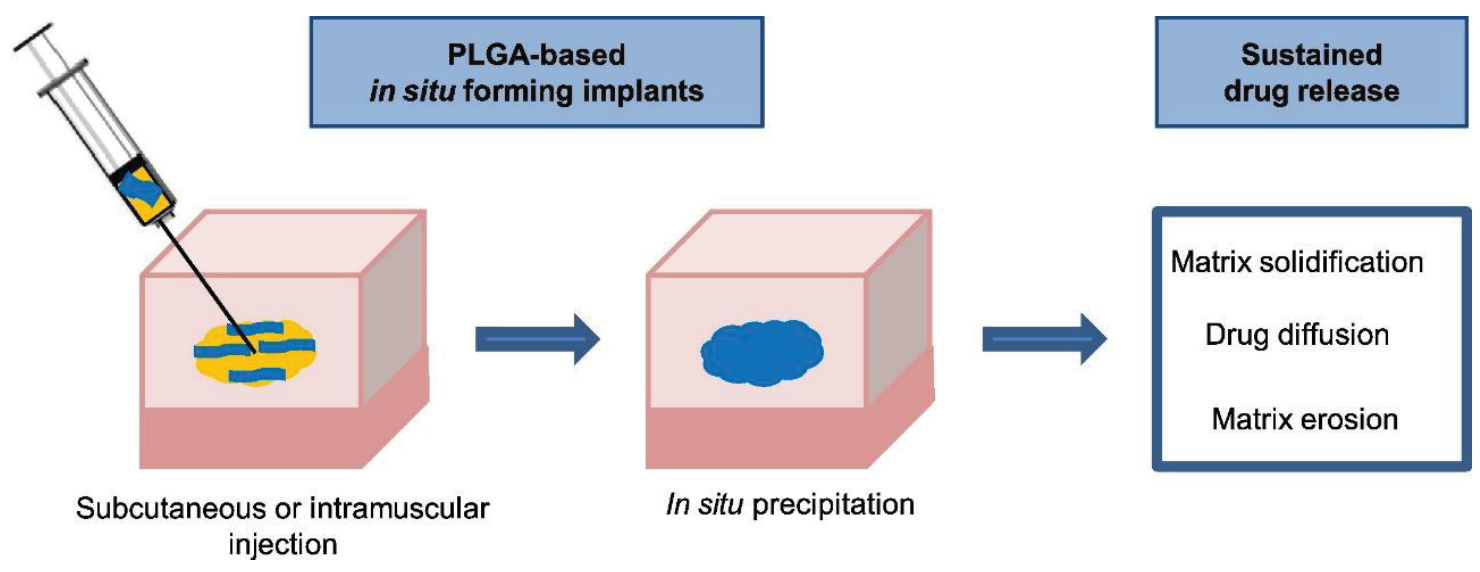

Figure 3-5. Phase inversion based in situ forming depot

Phase-sensitive PLGA based in situ forming depot precipitates and forms solidified PLGA matrix after injection. Drug is released in a sustained manner from the matrix via diffusion and matrix erosion.

Reprinted from Journal of controlled release, 172(1), Parent, M., Nouvel, C., Koerber, M., Sapin, A., Maincent, P., \& Boudier, A., PLGA in situ implants formed by phase inversion: Critical physicochemical parameters to modulate drug release, 292-304, 2013, with permission from Elsevier. 
systems have been developed and evaluated for their ability to provide controlled release of various proteins and peptides $[174,175]$. Insulin has also been used as a drug in phase inversion based in situ forming depots for longer release, although there are very few reports available which are mostly based on PLA and PLGA.

Kang et al. used PLA as a polymer to develop a phase inversion based system for controlled delivery of insulin [176]. The delivery system was prepared by dissolving PLA $(15$ or $30 \% \mathrm{w} / \mathrm{v})$ in benzyl benzoate (BB) and benzyl alcohol (BA) solvent mixture and insulin was mixed at a level of $4 \%(\mathrm{w} / \mathrm{v})$. The systems released $15-75 \%$ insulin for more than 2 months in vitro. A change in insulin release was observed when hydrophilic (benzyl alcohol) and hydrophobic (benzyl benzoate) solvent ratio and polymer concentration were changed. Histopathological study showed that the system was nontoxic after 12 weeks of implantation. Although the system showed promising sustained release data in in vitro study, the system's performance is inconclusive due to the lack of in vivo data. However, Dhawan et al. performed a similar study with PLGA containing phase inversion based system by varying the solvent ratio of benzyl benzoate and benzyl alcohol [177]. Several formulations were developed by changing the PLGA, BB and BA concentration and in vivo glucose lowering effect was tested on diabetic male LACA mice. The formulation composed of $2 \mathrm{mg} / \mathrm{g}$ insulin, $30 \mathrm{wt} \%$ PLGA and 20\% (w/v) BB and $80 \%(\mathrm{w} / \mathrm{v})$ BA showed glucose lowering effect for 16 days after a single injection compared to routine once-a-day insulin administration. SDS-PAGE and CD spectroscopy revealed that insulin released from the formulation in in vitro study was conformationally stable.

In a similar study, Anand et al. developed another PLGA based phase inversion based systems composed of triethyl citrate (TEC) and acetyltriethyl citrate (ATEC) as plasticizer [178]. The formulations were composed 4\% (w/w) insulin glargine and 5\% $(\mathrm{w} / \mathrm{w})$ PLGA dissolved in ATEC and TEC mixture with or without zinc sulfate (0.1$0.5 \%$ ). The PLGA gel formulations prepared with insulin glargine particles maintained normal blood glucose level for 10 days after a single subcutaneous injection but showed a sudden blood glucose drop in diabetic ZDF rats possibly due to high initial burst. Addition of zinc sulfate slowed down the blood glucose drop in a concentration dependent manner (Figure 3-6). The use of long-acting insulin analogue glargine and addition of zinc combinedly promoted hexamer formation leading to slower insulin release and steady blood glucose drop in this study. As a result, sustained insulin release was achieved for more than one week even with low concentration of polymer solution $(5 \% \mathrm{w} / \mathrm{w})$ which provided easy injectability.

\section{Glucose Responsive In Situ Forming Depots}

Apart from thermo-sensitive and phase inversion based in situ forming depots, one new kind of gel based system is glucose responsive polymeric gels developed by coencapsulation of insulin with glucose responsive enzyme such as glucose oxidase. High glucose concentration triggers glucose oxidase mediated conversion of glucose into gluconic acid which causes local $\mathrm{pH}$ drop. Consequently, the polymeric matrix is swelled 


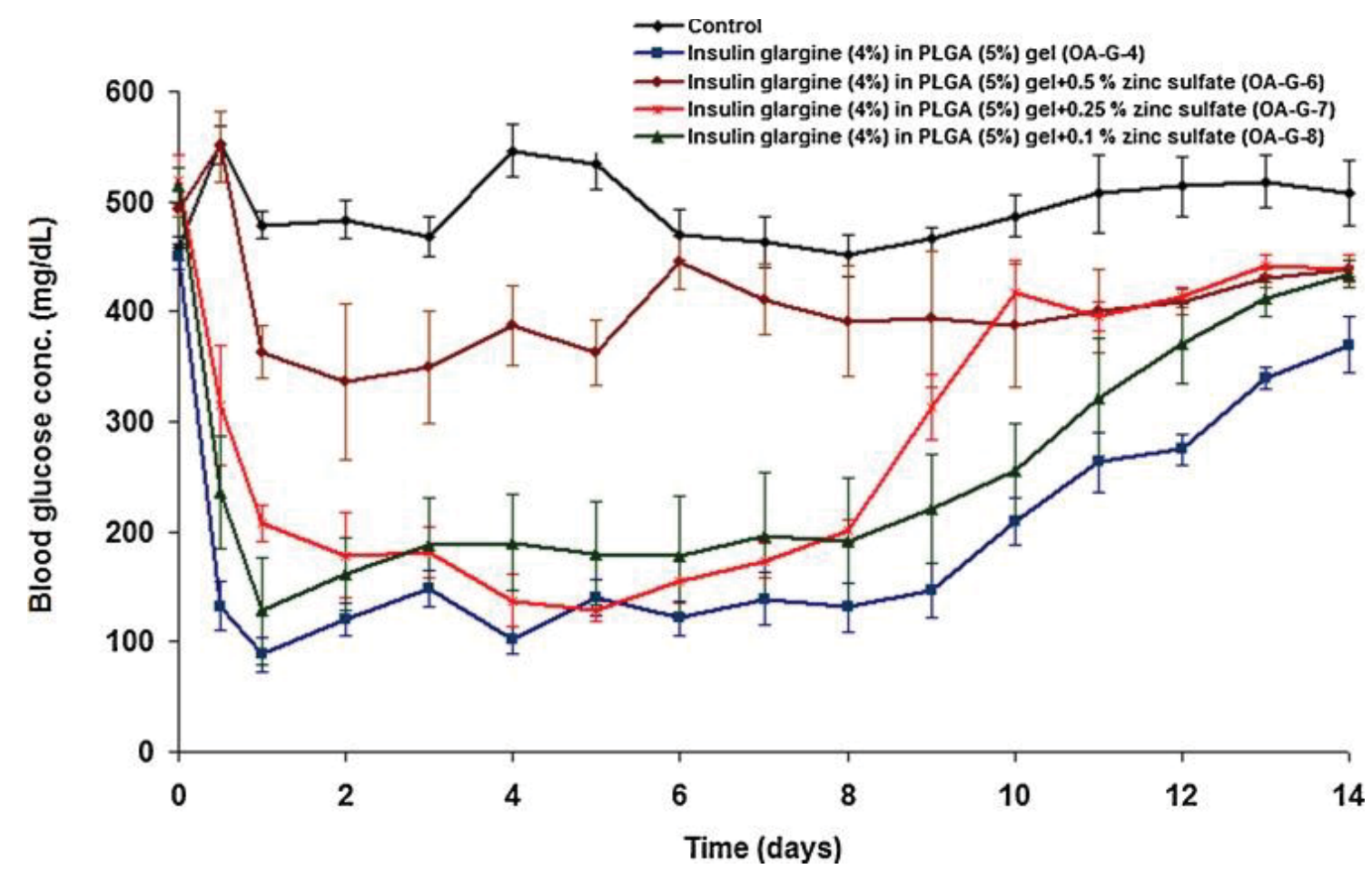

Figure 3-6. Comparison of blood glucose lowering effect of PLGA phase inversion based in situ forming depot with various zinc sulfate concentrations in ZDF rats

Reprinted by permission from The American Association of Pharmaceutical Scientists: Springer Nature, AAPS PharmSciTech, Controlled release of modified insulin glargine from novel biodegradable injectable gels Anand, O., Almoazen, H., Mehrotra, N., Johnson, J. and Shukla, A., 2012. 
and degraded causing insulin release which is stopped when blood glucose returns to normal level. One example of such system has been found so far which was developed by Fu et al. and utilized a pH sensitive peptide hydrogel called RATEA-16 [179]. RATEA16 hydrogel undergoes self-assembly in physiological $\mathrm{pH}$ but is disassembled in low environmental $\mathrm{pH}$. After injection, insulin and glucose oxidase loaded hydrogel is selfassembled at physiological $\mathrm{pH}$. In hyperglycemic condition, the conversion of glucose into glucuronic acid decreased the local $\mathrm{pH}$ resulting in the disassembly of hydrogel resulting in slow insulin release. The system regulated the blood glucose levels of STZinduced diabetic rats effectively for up to 8 days.

As discussed, thermosensitive systems are mostly composed of block copolymers with hydrophobic and hydrophilic content whereas phase-sensitive systems are developed with polymers which are soluble in organic solvents such as NMP and DMSO etc. Thermo-sensitive systems can be tuned to vary the rate of insulin release by altering hydrophilic/hydrophobic content of the copolymer [156] as well as by varying the properties of the copolymer components [164, 172]. Similarly, phase inversion based in situ forming depots can be developed with tunable release properties by varying the polymer concentration, solvent composition, and by the addition of additives $[180,181]$. Regardless of the system, polymer concentration of $15-30 \%$ has been found to demonstrate sustained insulin release for at least one week while maintaining the ease of injectability. However, phase inversion based systems suffer from issues inherent to this system such as local irritation at the injection site due to high amount of organic solvent, polymer instability in the solvent system and denaturation of protein drugs in the presence of organic solvents [147]. In this respect, thermo-sensitive systems are usually preferred for the development of in situ forming depots for sustained insulin release especially due to the absence of organic solvent. However, high initial burst, unpredictable release kinetics, poor in vitro-in vivo correlation, variation in implant size, incomplete implant formation, protein instability due to protein-polymer interaction as well as increase in local $\mathrm{pH}$ due to polymer degradation remain issues in both systems [146, 147, 181-184]. Like microspheres, high initial burst during the first few hours after injection is also crucial as it might cause severe hypoglycemia $[185,186]$. However, addition of zinc, cationic polymers and use of long-acting insulin analogues have been found to improve the burst release $[153,178]$. In addition to this, development of robust in vitro release method that can predict the in vivo release profile from the in situ implant can resolve the issues related to poor in vitro-in vivo correlation and accelerate formulation screening. But unpredictable release kinetics still remains an unresolved problem in this respect even after employing several novel imaging techniques to evaluate implant formation and subsequent drug release kinetics [183, 187].

\section{Nanoparticles}

Nanoparticles are carriers with a size range of 10-1000 nm [101]. The emergence of nanoparticle-based drug delivery systems has revolutionized the area of protein and peptide drug delivery. Owing to their advantage of transporting drugs across various biological barriers, improved bioavailability and target specific delivery, nanoparticle- 
based drug delivery systems has been widely studied for protein and peptide delivery in the past decade $[188,189]$.

Nanoparticle-based delivery systems have been mainly investigated for efficient oral delivery of insulin because of their smaller size, enhanced pharmacokinetic property and protective nature towards encapsulated insulin [190-192]. But there are few reports on nanoparticles as a sustained release carrier for insulin delivery. One such study investigated sustained release behavior of insulin loaded positively charged dialkylaminoalkyl-amine-poly(vinyl alcohol)-g-poly(lactide-co-glycolide) co-polymer based nanoparticles with a size range of $122.7 \mathrm{~nm}$ to $1762.4 \mathrm{~nm}$ [193]. The positively charged copolymer formed nanoparticles with negatively charged insulin via ion mediated nanoparticle aggregation. After subcutaneous injection, the aqueous suspension of nanoparticle aggregates formed an in situ depot which released insulin in vitro for about two weeks. The release profile showed triphasic insulin release starting from initial burst, then pore diffusion and finally insulin release from swollen matrix which is typical in particle based sustained release systems [194]. However, no in vivo study of this system was reported.

Nanoparticles prepared from commonly used polymers have been investigated and sustained in vivo insulin release has been achieved for several days. Abdelkader et al. developed PLGA nanoparticles with size ranging from 200-300 $\mathrm{nm}$ and these nanoparticles released more than $60 \%$ of insulin for more than 6 days in in vitro release study [195]. Subcutaneous injection of optimized nanoparticle formulation demonstrated significant glucose lowering effect in STZ-induced male SD diabetic rats throughout the six days study compared to free human insulin and insulin-zinc suspension. After 6 days, the $\%$ basal glucose level was $86.8 \%$ for nanoparticle formulations whereas $\%$ basal glucose level increased to approximately $106 \%$ for both free human insulin and insulinzinc suspension. In another study, Haggag et al. reported insulin loaded PLGA-PEG block copolymer based nanoparticles via a slight modification of traditional double emulsion-solvent evaporation method (Figure 3-7) [196]. Increase in PEG content was found to increase the encapsulation efficiency of insulin which might be due to the hydrophilicity of PEG that promotes higher insulin attachment on nanoparticle surface. The nanoparticles were negatively charged with a size range of 200-400 nm and the size was increased with the increase in PLGA content. Also, Subcutaneous injection of insulin loaded nanoparticles, at $25 \mathrm{U} / \mathrm{kg}$ body weight dose and 10\% PEG content, demonstrated sustained hypoglycemic effect for 6 days in STZ-induced diabetic Swiss TO mice.

Nanoparticle based sustained insulin release has been studied with less commonly used biopolymers such as poly(hydroxybutyrate-co-hydroxyhexanoate) (PHBHHx) copolymer [197]. In this study, insulin was first complexed with phospholipid (soybean lecithin) to increase the lipohilicity of insulin which in turn increased the encapsulation efficiency in PHBHHX nanoparticles. The mean particle size of the nanoparticles was $186.2 \mathrm{~nm}$ and the nanoparticles showed very slow in vitro insulin release given that only $20 \%$ of insulin was released within the first 31 days. However, the nanoparticles, at a dose of $4 \mathrm{IU} / \mathrm{kg}$, maintained hypoglycemic effect in STZ induced diabetic rats for more than 3 days after single subcutaneous injection. The blood glucose level remained less 


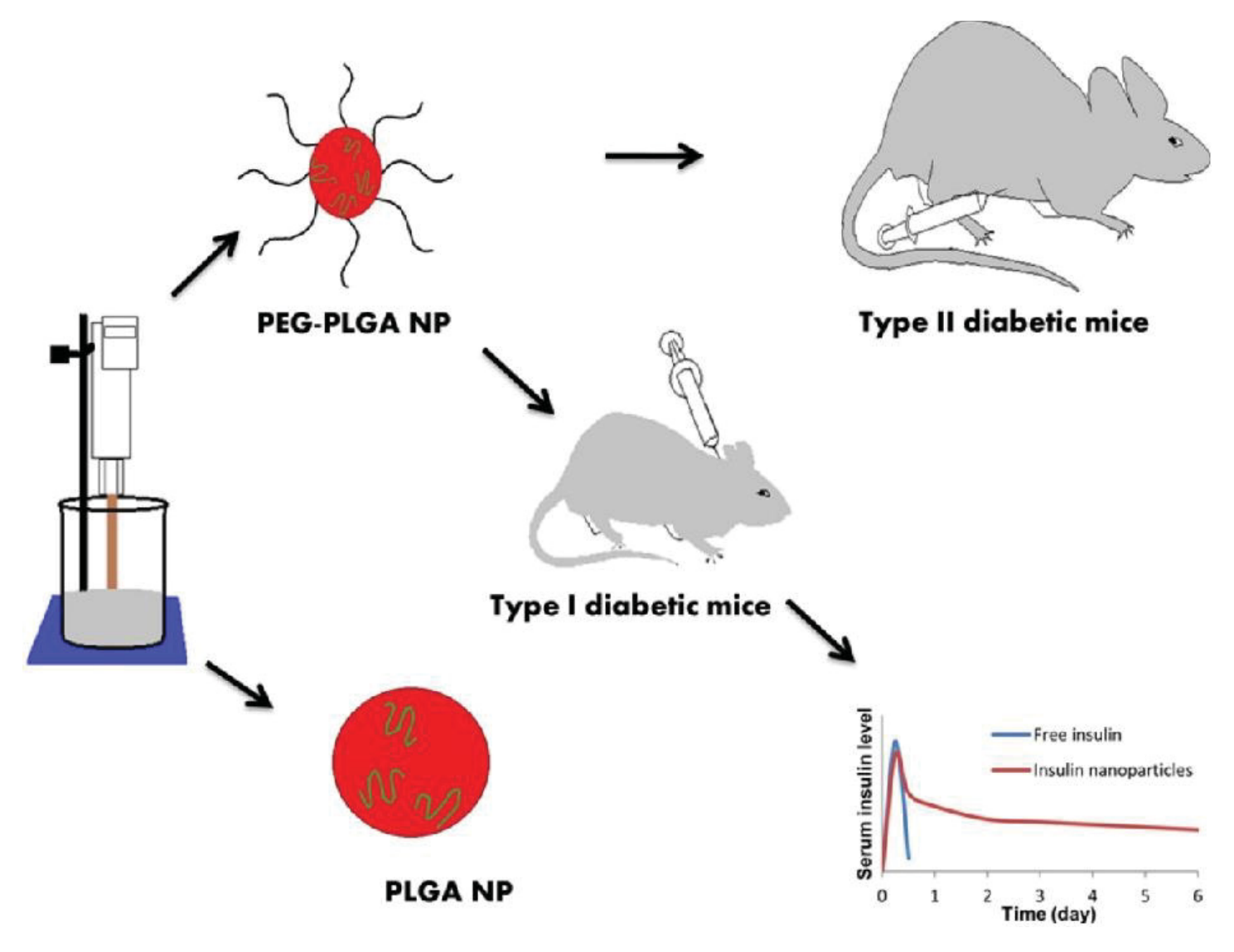

Figure 3-7. Sustained release PEG-PLGA nanoparticles

PEG-PLGA block copolymer based insulin loaded nanoparticles synthesized via double emulsion-solvent evaporation method. Insulin maintained its conformational stability in nanoparticles demonstrated in insulin sensitivity study in type 2 diabetic mice as well as showed normoglycemia for 6 days.

Reprinted from International journal of pharmaceutics, 499(1-2), Haggag, Y., AbdelWahab, Y., Ojo, O., Osman, M., El-Gizawy, S., El-Tanani, M., Faheem, A. and McCarron, P., Preparation and in vivo evaluation of insulin-loaded biodegradable nanoparticles prepared from diblock copolymers of PLGA and PEG, 236-246, 2016, with permission from Elsevier. 
than $70 \%$ of initial level during this time.

Enzymes have been incorporated into the nanoparticle to achieve enzyme mediated degradation of nanoparticles to release insulin in sustained manner (Figure 3-8). Chou et al. developed insulin loaded self-assembled nanoparticles of $40 \mathrm{~nm}$ size with carboxymethyl-hexanoyl chitosan and co-encapsulated with lysozyme to achieve enzyme mediated degradation of nanoparticles [198]. $10 \mu \mathrm{g} / \mathrm{ml}$ lysozyme containing insulin loaded chitosan nanoparticles were injected subcutaneously in STZ-induced diabetic male BLTW:CD1 (ICR) mice. The nanoparticles were degraded by lysozyme and as a result, insulin was released slowly from the system. The nanoparticles with lysozyme maintained normoglycemia for 10 days with a stable blood glucose level whereas the nanoparticles without lysozyme showed normoglycemia for less than 5 days.

Glucose-responsive nanoparticle has been emerged as a newer strategy in the last few years for sustained delivery of insulin [28]. As we know that blood glucose concentration is the central stimuli for native insulin secretion from pancreas, glucose responsive nanoparticles can release insulin in response to the glucose concentration i.e. insulin is released from the system when the glucose concentration rises and is stopped when glucose level returns to normal. Gu et al. developed glucose responsive dextran nanoparticles with a size range of 290-340 nm by encapsulating insulin and glucoseresponsive enzymes such as glucose oxidase and catalase [199]. The dextran nanoparticles were then coated with either positively charged chitosan or negatively charged alginate which, when mixed together, formed a nano network (Figure 3-9). In hyperglycemic condition, glucose oxidase mediated conversion of glucose into gluconic acid increased the $\mathrm{pH}$ of the environment surrounding nanoparticles. As a result, the nano network underwent $\mathrm{pH}$ mediated degradation and released insulin slowly. The insulin release was halted when the glucose concentration returned to normal. A single subcutaneous injection of these nanoparticles maintained normoglycemia for up to 10 days in STZ-induced diabetic male C57B6 mice. Conversely, insulin loaded nano network in the absence of glucose-specific enzyme maintained blood glucose level within the normal range for only 2 days.

Xu et al. developed another intelligent glucose-responsive nano system mesoporous silica nanoparticles [200]. Instead of encapsulating glucose specific enzymes with insulin, the porous surface of the nanoparticles was covered with a layer-by-layer coating of enzymes (glucose oxidase and catalase) and polyethyleneimine (PEI) (Figure 3-10). When glucose level is more than $7 \mathrm{mM}$, the conversion of glucose into gluconic acid increased the surrounding $\mathrm{pH}$. The increase in $\mathrm{pH}$ caused protonation of PEI which resulted in repulsion and subsequent loosening of the PEI layers. Hence, insulin was released through the pores of the nanoparticles. In normoglycemic condition, the PEI layer maintained its integrity and prevented insulin release. Upon single subcutaneous injection, the nanoparticles decreased the blood glucose level and maintained normoglycemiafor more than 3 days. The design of these nanoparticles allows tunable insulin release by adjusting the amount of PEI in the nanoparticles.

Glucose responsive moiety such phenylboronic acid has been incorporated as a 


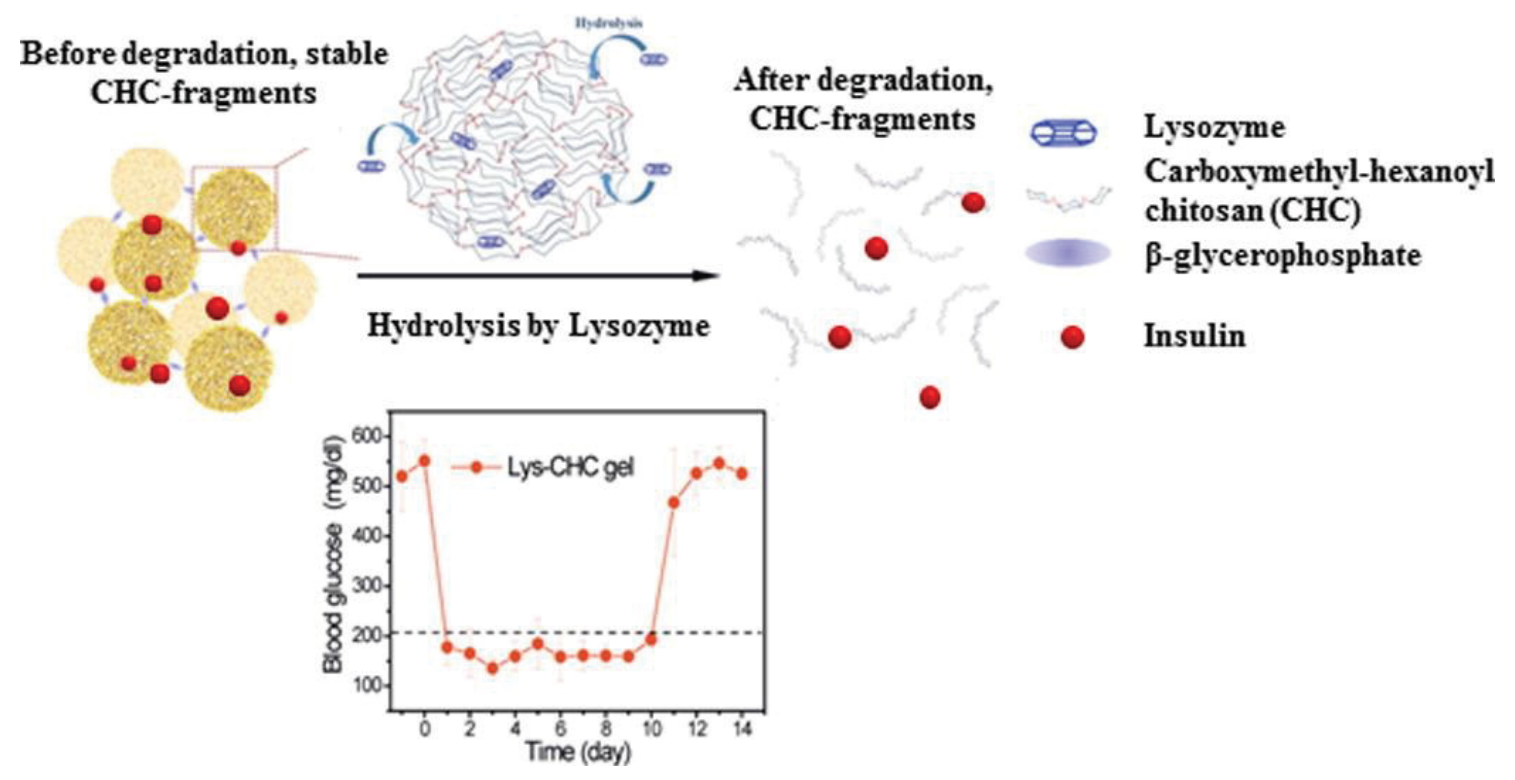

Figure 3-8. Enzyme loaded sustained release nanoparticles

Carboxymethyl-hexanoyl chitosan nanoparticles maintain normoglycemia via sustained insulin release mediated by lysozyme-controlled degradation of nanoparticles. Reprinted from Journal of controlled release, 224, Chou, H. S., Larsson, M., Hsiao, M. H., Chen, Y. C., Röding, M., Nydén, M., \& Liu, D. M., Injectable insulin-lysozymeloaded nanogels with enzymatically-controlled degradation and release for basal insulin treatment: In vitro characterization and in vivo observation, 33-42, 2016, with permission from Elsevier. 

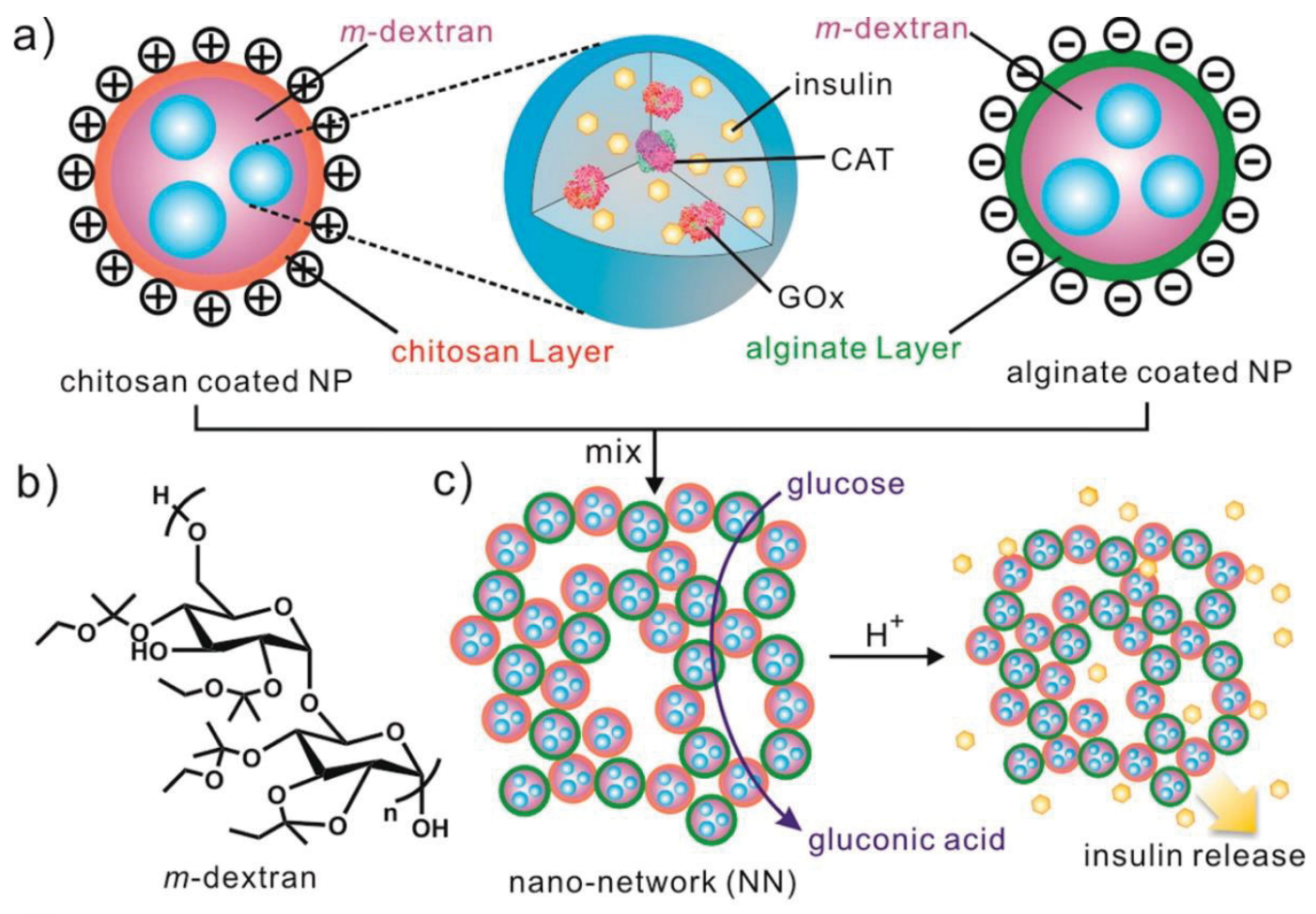

d)

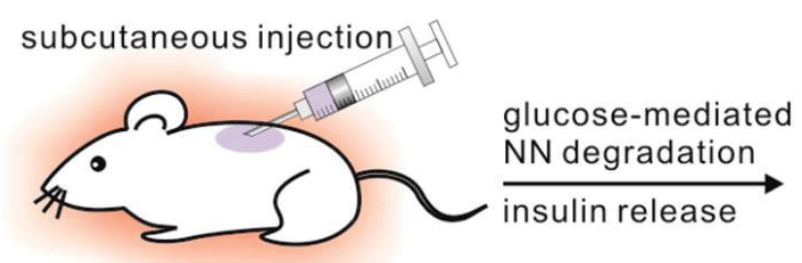

hyperglycemia

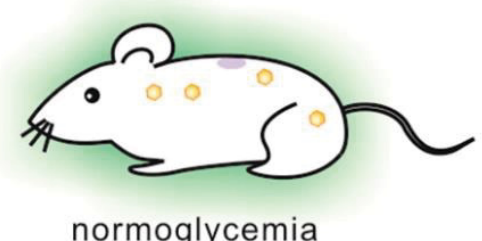

normoglycemia

Figure 3-9. Sustained release of insulin from nano-network

(a) Formation of oppositely charged acid sensitive dextran nanoparticles encapsulating insulin, glucose oxidase and catalase, (b) acid sensitive acetal-modified dextran, (c) Sustained insulin release via $\mathrm{pH}$ mediated degradation of nano network caused by glucose oxidase mediated glucose to gluconic acid conversion, (d) treatment of type 1 diabetic mice with glucose-responsive nanoparticles to maintain normoglycemia. Reprinted with permission from Gu, Z., Aimetti, A.A., Wang, Q., Dang, T.T., Zhang, Y., Veiseh, O., Cheng, H., Langer, R.S. and Anderson, D.G. (2013). Injectable nano-network for glucose-mediated insulin delivery. ACS nano, 7(5), 4194-4201. 2013 American Chemical Society. 


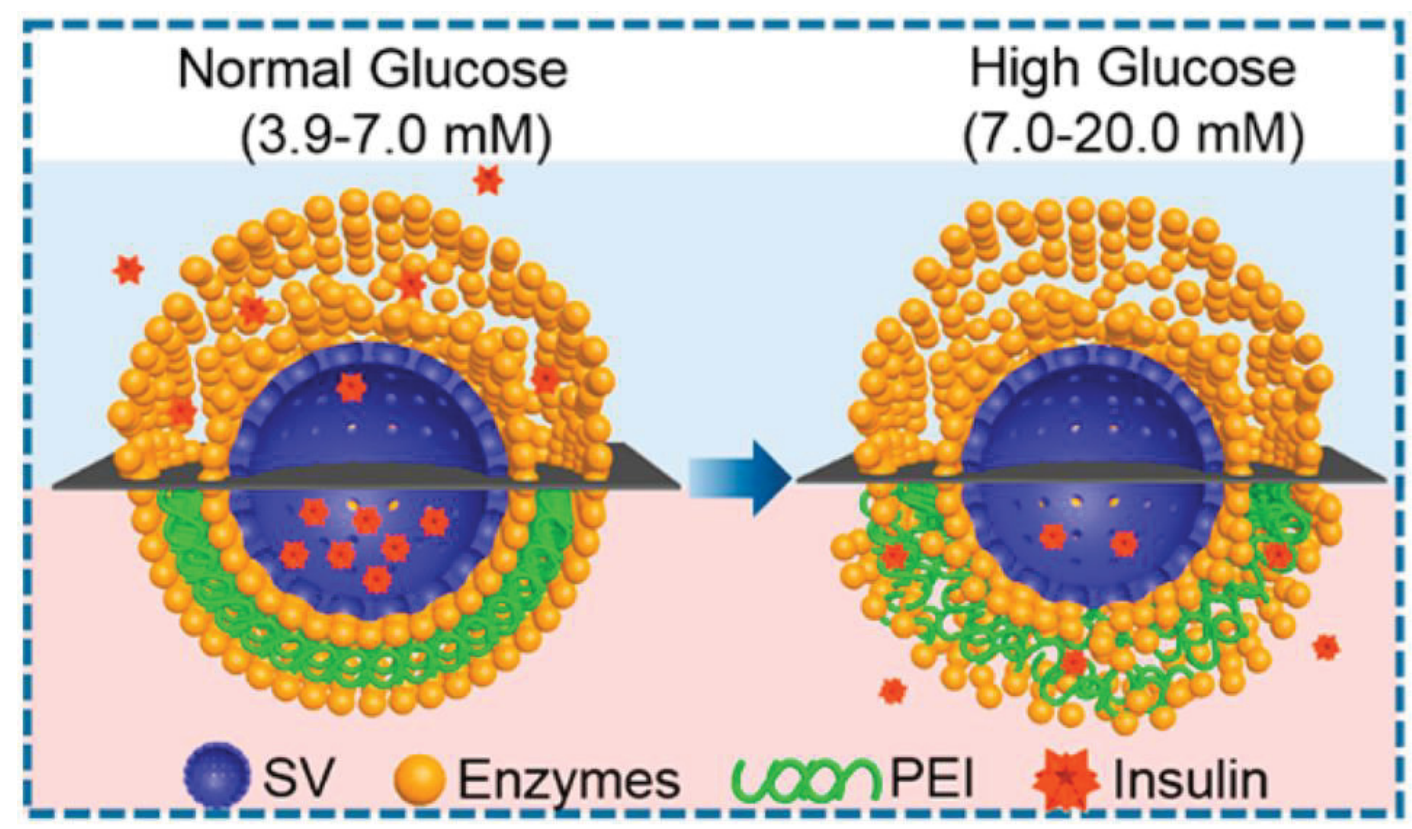

Figure 3-10. Glucose responsive enzyme coated nanoparticles

Layer-by-layer coating of insulin containing mesoporous silica nanoparticle surface with glucose-specific enzyme and PEI. The nanoparticles release insulin in a sustained manner in response to high glucose concentration by enzyme mediated increase in local $\mathrm{pH}$. Reprinted with permission from Xu, C., Lei, C., Huang, L., Zhang, J., Zhang, H., Song, H., Yu, M., Wu, Y., Chen, C. and Yu, C. (2017). Glucose-responsive nanosystem mimicking the physiological insulin secretion via an enzyme-polymer layer-by-layer coating strategy. Chemistry of Materials, 29(18), 7725-7732. 2017 American Chemical Society. 
component of block copolymer to achieve glucose responsive sustained insulin release [201]. For example, poly(d-gluconamidoethyl-methacrylate-block-3-

acrylamidophenylboronic-acid) (p(AAPBA-b-GAMA)) amphiphilic block glycopolymer has been synthesized to develop self-assembled nanoparticles [202]. The self-assembly occurred via cross-linking between diol groups of pAAPBA and pGAMA blocks. The nanoparticles released up to $50 \%$ of encapsulated insulin for 48 days in in vitro release study in conformationally stable form, although in vivo sustained release property of these nanoparticles is yet to be explored [203, 204].

Nanoparticle based drug delivery possess several advantages such as targeted delivery, superior penetration ability through biological barriers, prolonged circulation time, enhanced permeation and retention ability and therefore, have been investigated for their potential in different therapeutic areas. But studies regarding the use of nanoparticles for sustained delivery of insulin is sparse and mostly limited to in vitro studies. Furthermore, nanoparticle based sustained release systems, in general, demonstrate several issues similar to microspheres such as variation between in vitro and in vivo drug release profile, migration from the injection site and stability issues during the nanoparticle synthesis process. Moreover, owing to their smaller size compared to microspheres, nanoparticles often show lack of efficient renal clearance after drug release and long-term safety concerns [205]. Although some studies reported sustained insulin release for several days (maximum 10 days) using different nano systems, the breadth of publications in this area is very limited to evaluate the potential of nanoparticles for longacting insulin therapy.

\section{Composite Systems}

Particle based sustained release systems such as microspheres and nanoparticles have demonstrated sustained insulin release and maintained normoglycemia for prolonged duration [108, 115, 153, 176, 196, 198, 206]. However, both microsphere- and nanoparticle-based delivery systems possess some inherent disadvantages such as high initial burst, migration from injection site and occasionally, stability issues during encapsulation [134, 137, 205]. Composite systems such as particle-gel or particle-particle hybrid systems have been investigated in several studies to overcome these issues. Zhao et al. recently developed one composite system with phenylboronic acid (PBA) modified PLGA microspheres loaded in dopamine modified hyaluronic acid hydrogel (DOP-HA) [207]. At a low glucose level, PBA crosslinked with dopamine to form hyaluronic acid layer around microspheres which acted as a diffusion barrier for insulin encapsulated in microsphere (Figure 3-11). At a high glucose level, PBA-DOP crosslinking is disrupted, and the hyaluronic acid layer detached from the microsphere resulting in insulin release through pores. After subcutaneous injection, the insulin loaded microsphere-gel composite system achieved normoglycemia for two weeks in STZ induced diabetic mice. The advantage of this system is that it involves simple mixing and self-assembly of the formulation components which can facilitate scaling up of this system for clinical translation. 
A

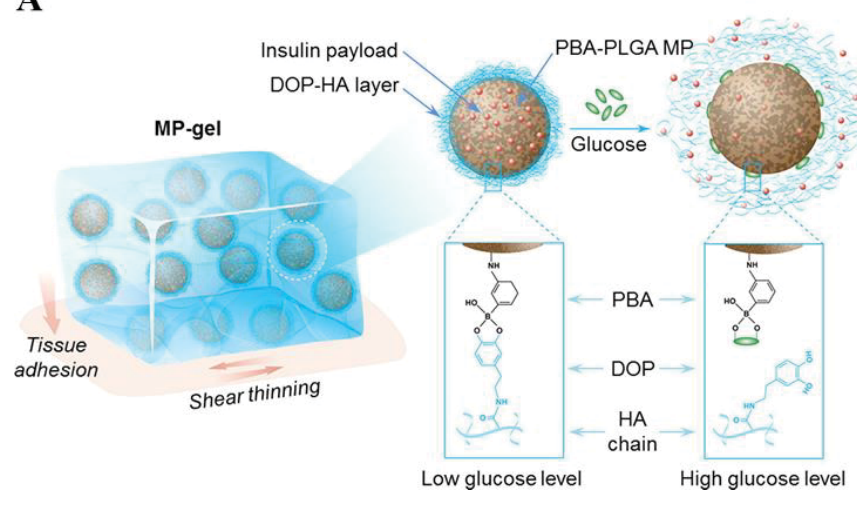

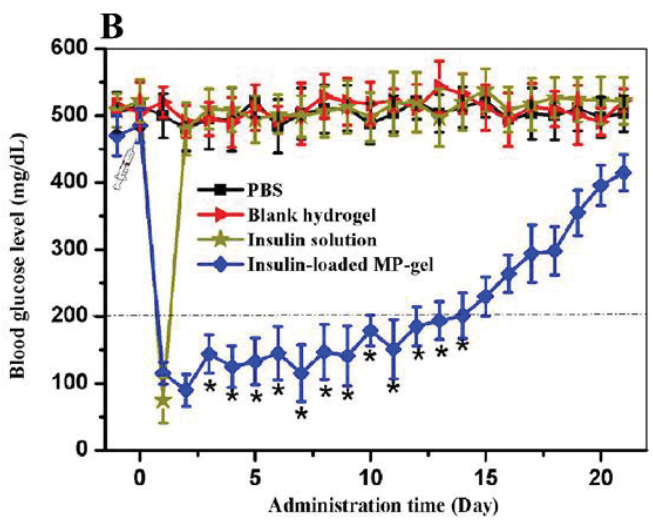

Figure 3-11. Microsphere-gel based composite system

A: Microsphere-gel (MP-gel) composite system composed of phenylboronic acid (PBA) modified poly(lactic-co-glycolic acid) (PLGA) microspheres coated with dopamine (DOP) modified hyaluronic acid (HA) layer. At low glucose level, the DOP-HA layer is densely packed on the microsphere surface which prevents insulin release.

B: At high glucose level, the DOP-HA layer is detached from the microsphere surface causing sustained insulin release compared to PBS, MP-gel without insulin, free insulin solution resulted prolonged normoglycemia.

Adapted from Acta biomaterialia, 64, Zhao, F., Wu, D., Yao, D., Guo, R., Wang, W., Dong, A., Kong, D. and Zhang, J., An injectable particle-hydrogel hybrid system for glucose-regulatory insulin delivery, 334-345, 2017, with permission from Elsevier. 
Similar to microsphere embedded hydrogel system, Liu et al. developed a controlled release system for insulin with PLGA nanoparticle embedded within PVA hydrogel via physical cross-linking [208]. Insulin loaded PLGA nanoparticles with a mean size of $615 \mathrm{~nm}$ were prepared by traditional double emulsion-solvent evaporation technique and dispersed in 5\% w/v PVA solution. The delivery system released insulin in a sustained manner and maintained normal blood glucose level for 24 hours in diabetic mice after one intraperitoneal injection. Although the delivery system maintained normoglycemia similar to long acting insulin analogues, the intraperitoneal route is a significant concern because of its invasive nature compared to traditional subcutaneous route. In a previous study mentioned in section 4.3, Peng et al. demonstrated that insulinphospholipid complex loaded PHBHHx nanoparticles maintained therapeutic effect of insulin in diabetic rats for more than 3 days [197]. In a follow-up study, the same group loaded these nanoparticles in thermosensitive chitosan/ $\beta$-glycerophosphate injectable hydrogel to achieve longer action-time profile of insulin [209]. The glucose lowering effect of this composite system lasted for more than 5 days in diabetic SD rats following single subcutaneous injection (Figure 3-12). This is an excellent example of modifying existing sustained release system to achieve longer release profile that can be applied to other particle based sustained release systems as well.

Another novel strategy in this regard is the development of nanoparticle embedded microsphere based systems [210]. These nanoparticle-in-microsphere systems showed longer drug release profile compared to nanoparticle or microsphere alone [211]. Hasan et al. developed insulin loaded PCL nanoparticles encapsulated in PLGA microsphere [212]. PCL nanoparticles $(390 \pm 17 \mathrm{~nm})$ were prepared by w/o/w doubleemulsion solvent evaporation method and then encapsulated in PLGA microspheres by w/o/w method. The size of the composite microspheres was $111 \pm 4 \mu \mathrm{m}$ and it released insulin for about 4 days after single subcutaneous injection into STZ-induced diabetic rats. Although these preclinical in vivo studies demonstrate that particle-particle or particle-gel based composite systems can provide sustained release of insulin, there are actually very few studies to assess the overall feasibility of composite systems in this respect. 


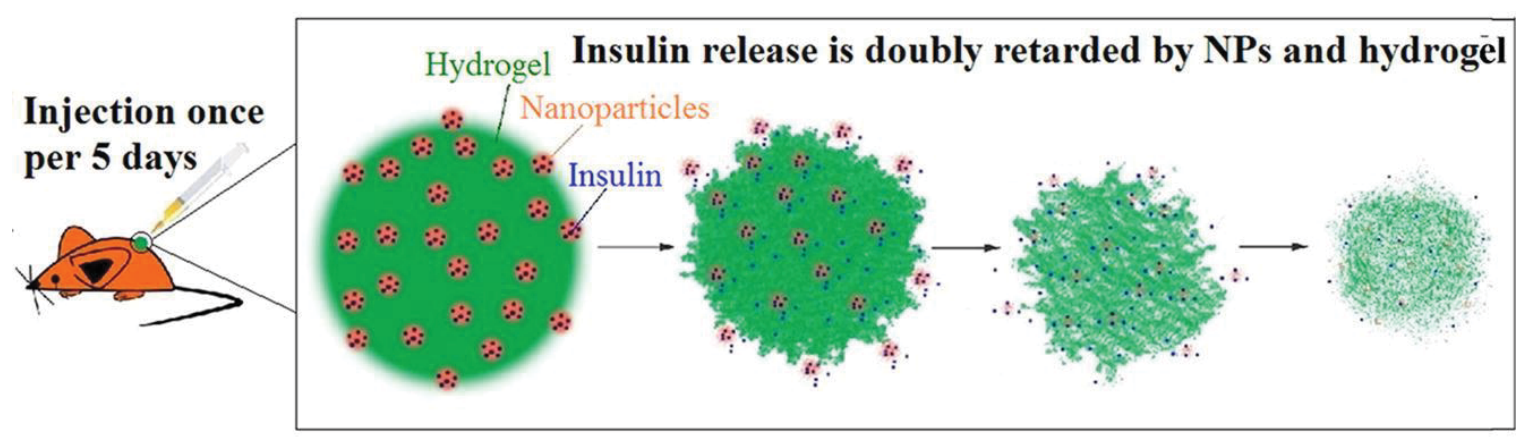

Figure 3-12. Nanoparticle-gel based composite system

Representation of nanoparticle loaded hydrogel based composite system. Insulin containing PHBHHx nanoparticle loaded in thermosensitive chitosan/ $\beta$-glycerophosphate injectable hydrogel retarded insulin release from nanoparticles and maintained normoglycemia for 5 days.

Reprinted from Acta biomaterialia, 9(2), Author(s), Peng, Q., Sun, X., Gong, T., Wu, C. Y., Zhang, T., Tan, J., \& Zhang, Z. R., 5063-5069, 2013, with permission from Elsevier. 


\title{
CHAPTER 4. INJECTABLE INSULINS IN CLINICAL TRIALS
}

Different injectable delivery systems such as microspheres, in situ forming depots, nanoparticles and composite systems have been explored for their potential to achieve ultra-long action of insulin. Although most of them have been limited to preclinical studies, a number of new candidates based on these delivery concepts are advancing towards clinical trials. In fact, four such candidates are currently in early stage clinical development which offer the hope of once-weekly insulin treatment in the near future (Table 4-1). Different delivery methods have been exploited to develop these candidates such as PEGylation, antibody or polypeptide conjugation and delivery via microsphere to achieve longer action-time profile. The following section discusses the design strategies and clinical status of these once-weekly insulin candidates.

\begin{abstract}
AB101
AntraBio's AB101 combines the concept of PEGylation and microsphere-based delivery system. As mentioned in section 3.1, it was developed by the attachment of $5 \mathrm{kD}$ linear polyethylene glycol (PEG) polymer with ThrB30 side-chain of native human insulin followed by encapsulation of the in PLGA microsphere [213]. Insulin is released from the microsphere in a sustained manner by diffusion and degradation of PLGA. Single dose subcutaneous administration of AB101 demonstrated slow onset, sustained insulin release and corresponding glucose reductions for 1 weeks in diabetic rats and dogs [214]. AntraBio Inc. recently announced first-in-human clinical trials of AB101 as a once weekly sustained release insulin delivery system [141]. This is the only microsphere-based insulin formulation which is in Phase I clinical trial.
\end{abstract}

\section{HM12460A ( ${ }^{\mathrm{LAPS}}$ Insulin) and HM12470 ( ${ }^{\mathrm{LAPS}}$ Insulin 115)}

Hanmi Pharmaceuticals developed novel insulin analogue called ${ }^{\text {LAPS }}$ Insulin and

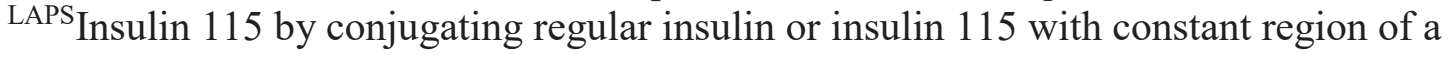
human immunoglobulin Fc fragment (LAPS carrier) through a $3.4 \mathrm{kD}$ PEG linker [215]. Both of the products deminstrated sustained insulin release and prolonged glucose lowering efficacy for more than a week with a reduction in weight gain in preclinical studies with pigs, SD rats and $d b / d b$ mice where HM12470 demonstrated better efficacy than HM12460 [216, 217]. Both products are undergoing phase I clinical trial.

\section{PE0139 (Insumera)}

PhaseBio Pharmaceuticals has developed PE0139 as a once weekly injection for the treatment of diabetes. In PE0139, native insulin molecule has been genetically fused to elastin-like polypeptide (ELP) biopolymer at AspA21 position. PE0139 is expressed in Escherichia Coli as a genetic fusion of ELP1-120 biopolymer and proinsulin. The 
Table 4-1. Injectable sustained release systems for insulin under clinical trials

\begin{tabular}{lllll}
\hline Name & Company & $\begin{array}{l}\text { Structural } \\
\text { Design }\end{array}$ & $\begin{array}{l}\text { Dosing } \\
\text { Frequency }\end{array}$ & $\begin{array}{l}\text { Clinical } \\
\text { Trial } \\
\text { Status }\end{array}$ \\
\hline NN1436 (LAI287) & Novo Nordisk & Not disclosed & $\begin{array}{l}\text { Once } \\
\text { weekly }\end{array}$ & Phase I \\
AB101 & AntriaBio Inc. & $\begin{array}{l}\text { PEGylated } \\
\text { Onsulin } \\
\text { encapsulated in } \\
\text { weekly }\end{array}$ & Phase I \\
& & $\begin{array}{l}\text { PLGA } \\
\text { microspher }\end{array}$ & & \\
& & $\begin{array}{l}\text { Fc-insulin } \\
\text { conjugate }\end{array}$ & $\begin{array}{l}\text { Once } \\
\text { weekly }\end{array}$ & Phase I \\
$\begin{array}{l}\text { HM12460A/HM12470) } \\
\text { (LAPS Insulin/LAPS Insulin }\end{array}$ & Pharmaceuticals & $\begin{array}{l}\text { Once } \\
\text { 115) }\end{array}$ & Plastin-like \\
PE0139 (Insumera) & PhaseBio & Phase \\
& & fusion & IIa \\
\hline
\end{tabular}

Sources: Zaykov, A. N., Mayer, J. P., \& DiMarchi, R. D. (2016). Pursuit of a perfect insulin. Nature Reviews Drug Discovery, 15(6), 425. Cheung, K. K. T., \& Senior, P. A. (2015). Novel and emerging insulin preparations for type 2 diabetes. Canadian journal of diabetes, 39, S160-S166. 
proinsulin is then converted into insulin during the downstream processing [218, 219]. In phase I clinical study, PE0139 demonstrated prolonged insulin release along with low peak-to-trough ratio that would enable once-weekly dosing regimen [220]. The molecule is now in Phase 2a clinical trial [221].

\section{NN1436 (LAI287)}

LAI287 also known as insulin-287 is a once weekly insulin analogue developed by Novo Nordisk. LAI287 has been reported as a lipidated insulin analogue but the detailed design of the analogues is undisclosed [213]. The phase I clinical trials have been completed and the company expects to initiate the Phase II clinical trials very soon [222]. 


\section{CHAPTER 5. CONCLUSION AND PERSPECTIVE}

Since its discovery, insulin has been the mainstay of treatment for diabetes mellitus for nearly 100 years. However, achieving normoglycemia for a prolonged time while avoiding the risk of hypoglycemia as well as achieving patient compliance and medication adherence through less frequent injection have always been major challenges with insulin therapy. The longest acting insulin available in the market requires oncedaily injection to maintain desired glucose lowering effect which is still inconvenient for patients and therefore, presents significant risk of medication non-adherence. Thus, several strategies have been explored over the past few decades to prolong the actiontime profile of insulin to obviate the need of once-daily injection. These strategies have been divided into two categories: altering amino acid sequences and/or chemical conjugation with polymers to develop long acting insulin analogues and developing sustained release delivery systems such as microspheres, in situ forming depots, nanoparticles and composite systems. The sustained release systems have been successfully demonstrated to release insulin for days to weeks in preclinical studies. However, one major drawback of these preclinical studies is that the system's performance is only measured by measuring glucose lowering effect which is an indicator of short-term glycemic control. These preclinical reports lack HbAlc reduction study which is more relevant for measuring the performance of long-lasting insulin therapy. Also, there are several other limitations such as lack of compendial in vitro release method, insulin instability, loss of biological activity, poor in vitro-in vivo correlation, higher initial burst, migration of the particle based systems from the injection site, manufacturing costs, need for reconstitution and sometimes unpredictable in vivo release from the delivery systems, which need to be addressed for successful translation of these preclinical strategies into clinical setting. However, advancements in recombinant DNA technology and protein chemistry coupled with the advances in material and formulation sciences as well as microfabrication techniques have been able to address some of these issues and enabled several once-weekly candidates to progress to the clinical trials. Future development efforts should focus on novel macromolecular modifications of insulin such as peptide and antibody conjugation as well as microspheres and in situ forming depots considering significant attention of FDA on the development of these complex sustained release delivery systems. In addition, glucose responsive systems should also be considered as focal point of research and developmental efforts as next generation injectable sustained release system for insulin. 


\section{LIST OF REFERENCES}

1. Centers for Disease Control and Prevention, National Diabetes Statistics Report, 2017. 2017, Atlanta, GA: Centers for Disease Control and Prevention, US Department of Health and Human Services.

2. Bommer, C., Sagalova, V., Heesemann, E., Manne-Goehler, J., Atun, R., Bärnighausen, T., Davies, J., \& Vollmer, S. (2018). Global Economic Burden of Diabetes in Adults: Projections From 2015 to 2030. Diabetes Care, dc171962. doi:10.2337/dc17-1962

3. American Diabetes, A. (2015). Standards of medical care in diabetes-2015 abridged for primary care providers. Clinical diabetes : a publication of the American Diabetes Association, 33(2), 97-111. doi:10.2337/diaclin.33.2.97

4. Weykamp, C. (2013). HbA1c: a review of analytical and clinical aspects. Ann Lab Med, 33(6), 393-400. doi:10.3343/alm.2013.33.6.393

5. Gregg, E. W., Sattar, N., \& Ali, M. K. (2016). The changing face of diabetes complications. The Lancet Diabetes \& Endocrinology, 4(6), 537-547. doi:https://doi.org/10.1016/S2213-8587(16)30010-9

6. Pechenov, S., Bhattacharjee, H., Yin, D., Mittal, S., \& Subramony, J. A. (2017). Improving drug-like properties of insulin and GLP-1 via molecule design and formulation and improving diabetes management with device \& drug delivery. Advanced Drug Delivery Reviews, 112, 106-122. doi:https://doi.org/10.1016/j.addr.2017.01.006

7. Hirsch, I. B. (2015). Glycemic Variability and Diabetes Complications: Does It Matter? Of Course It Does! Diabetes Care, 38(8), 1610-1614. doi:10.2337/dc142898

8. American Diabetes Association. (2018). 8. Pharmacologic Approaches to Glycemic Treatment: Standards of Medical Care in Diabetes-2018. Diabetes Care, 41 (Supplement 1), S73-S85. doi:10.2337/dc18-S008

9. Vaughan, E. M., Moreno, J. P., Hyman, D., Chen, T.-A., \& Foreyt, J. P. (2017). Efficacy of oral versus insulin therapy for newly diagnosed diabetes in lowincome settings. Archives of general internal medicine, 1(2), 17-22.

10. Weiss, M., Steiner, D. F., \& Philipson, L. H. (2014). Insulin biosynthesis, secretion, structure, and structure-activity relationships.

11. Carpenter, M. C., \& Wilcox, D. E. (2014). Thermodynamics of Formation of the Insulin Hexamer: Metal-Stabilized Proton-Coupled Assembly of Quaternary Structure. Biochemistry, 53(8), 1296-1301. doi:10.1021/bi4016567 
12. Becker, R. H. A. (2007). Insulin Glulisine Complementing Basal Insulins: A Review of Structure and Activity. Diabetes Technology \& Therapeutics, 9(1), 109-121. doi:10.1089/dia.2006.0035

13. Brange, J., Owens, D. R., Kang, S., \& Volund, A. (1990). Monomeric insulins and their experimental and clinical implications. Diabetes Care, 13(9), 923-54.

14. Fu, Z., Gilbert, E. R., \& Liu, D. (2013). Regulation of insulin synthesis and secretion and pancreatic Beta-cell dysfunction in diabetes. Current diabetes reviews, 9(1), 25-53.

15. Wollheim, C. B., \& Maechler, P. (2002). $\beta$-Cell mitochondria and insulin secretion: messenger role of nucleotides and metabolites. Diabetes, 51(suppl 1), S37-S42.

16. Regazzi, R., Mechanism of Insulin Exocytosis, in Advances in Molecular and Cell Biology, E.E. Bittar and S.L. Howell, Editors. 1999, Elsevier. p. 151-172.

17. Lang, J. (1999). Molecular mechanisms and regulation of insulin exocytosis as a paradigm of endocrine secretion. Eur J Biochem, 259(1-2), 3-17.

18. Ciszak, E., Beals, J. M., Frank, B. H., Baker, J. C., Carter, N. D., \& Smith, G. D. (1995). Role of C-terminal B-chain residues in insulin assembly: the structure of hexameric LysB28ProB29-human insulin. Structure, 3(6), 615-622. doi:https://doi.org/10.1016/S0969-2126(01)00195-2

19. Gast, K., Schüler, A., Wolff, M., Thalhammer, A., Berchtold, H., Nagel, N., Lenherr, G., Hauck, G., \& Seckler, R. (2017). Rapid-Acting and Human Insulins: Hexamer Dissociation Kinetics upon Dilution of the Pharmaceutical Formulation. Pharmaceutical research, 34(11), 2270-2286. doi:10.1007/s11095-017-2233-0

20. Dimitriadis, G., Mitrou, P., Lambadiari, V., Maratou, E., \& Raptis, S. A. (2011). Insulin effects in muscle and adipose tissue. Diabetes Research and Clinical Practice, 93, S52-S59. doi:https://doi.org/10.1016/S0168-8227(11)70014-6

21. Home, P. D. (2015). Plasma insulin profiles after subcutaneous injection: how close can we get to physiology in people with diabetes? Diabetes, Obesity and Metabolism, 17(11), 1011-1020. doi:doi:10.1111/dom.12501

22. P.V, J., Nair, S. V., \& Kamalasanan, K. (2017). Current trend in drug delivery considerations for subcutaneous insulin depots to treat diabetes. Colloids and Surfaces B: Biointerfaces, 153, 123-131. doi:https://doi.org/10.1016/j.colsurfb.2017.02.017

23. Rosenfeld, L. (2002). Insulin: discovery and controversy. Clin Chem, 48(12), 2270-88. 
24. Quianzon, C. C., \& Cheikh, I. (2012). History of insulin. Journal of community hospital internal medicine perspectives, 2(2), 10.3402/jchimp.v2i2.18701. doi:10.3402/jchimp.v2i2.18701

25. Shaw, K. L., Grimsley, G. R., Yakovlev, G. I., Makarov, A. A., \& Pace, C. N. (2001). The effect of net charge on the solubility, activity, and stability of ribonuclease Sa. Protein science : a publication of the Protein Society, 10(6), 1206-1215. doi:10.1110/ps.440101

26. Rendell, M. (2008). Insulin: moments in history. Drug Development Research, 69(3), 95-100. doi:doi:10.1002/ddr.20232

27. Heinemann, L., Linkeschova, R., Rave, K., Hompesch, B., Sedlak, M., \& Heise, T. (2000). Time-action profile of the long-acting insulin analog insulin glargine (HOE901) in comparison with those of NPH insulin and placebo. Diabetes Care, 23(5), 644-649. doi:10.2337/diacare.23.5.644

28. Gilroy, C. A., Luginbuhl, K. M., \& Chilkoti, A. (2016). Controlled release of biologics for the treatment of type 2 diabetes. Journal of Controlled Release, 240, 151-164. doi:https://doi.org/10.1016/j.jconrel.2015.12.002

29. Wiles, P. G., Guy, R., Watkins, S. M., \& Reeves, W. G. (1983). Allergy to purified bovine, porcine, and human insulins. British medical journal (Clinical research ed.), 287(6391), 531-531.

30. Grammer, L. (1986). Insulin allergy. Clinical Reviews in Allergy, 4(2), 189-200. doi: $10.1007 / \mathrm{bf} 02991108$

31. Chance, R. E., Root, M. A., \& Galloway, J. A. (1976). The immunogenicity of insulin preparations. Acta endocrinologica. Supplementum, 205, 185-198.

32. Schernthaner, G. (1993). Immunogenicity and allergenic potential of animal and human insulins. Diabetes Care, 16 Suppl 3, 155-65.

33. Vora, J., Cariou, B., Evans, M., Gross, J. L., Harris, S., Landstedt-Hallin, L., Mithal, A., Rodriguez, M. R., \& Meneghini, L. (2015). Clinical use of insulin degludec. Diabetes Research and Clinical Practice, 109(1), 19-31.

doi:https://doi.org/10.1016/j.diabres.2015.04.002

34. Teska, B. M., Alarcon, J., Pettis, R. J., Randolph, T. W., \& Carpenter, J. F. (2014). Effects of phenol and meta-cresol depletion on insulin analog stability at physiological temperature. J Pharm Sci, 103(8), 2255-67. doi:10.1002/jps.24039

35. Gualandi-Signorini, A., \& Giorgi, G. Insulin formulations-a review.

36. Halder, K., Wieland, M., \& Hartig, J. S. (2009). Predictable suppression of gene expression by 5'-UTR-based RNA quadruplexes. Nucleic acids research, 37(20), 6811-6817. 
37. Howey, D. C., Bowsher, R. R., Brunelle, R. L., \& Woodworth, J. R. (1994). [Lys(B28), Pro(B29)]-human insulin. A rapidly absorbed analogue of human insulin. Diabetes, 43(3), 396-402.

38. Herring, R., \& Russell-Jones, D. D. L. (2018). Lessons for modern insulin development. Diabetic Medicine, 35(10), 1320-1328. doi:doi:10.1111/dme.13692

39. Home, P. D., Barriocanal, L., \& Lindholm, A. (1999). Comparative pharmacokinetics and pharmacodynamics of the novel rapid-acting insulin analogue, insulin aspart, in healthy volunteers. European Journal of Clinical Pharmacology, 55(3), 199-203. doi:10.1007/s002280050618

40. Plank, J., Wutte, A., Brunner, G., Siebenhofer, A., Semlitsch, B., Sommer, R., Hirschberger, S., \& Pieber, T. R. (2002). A Direct Comparison of Insulin Aspart and Insulin Lispro in Patients With Type 1 Diabetes. Diabetes Care, 25(11), 2053-2057. doi:10.2337/diacare.25.11.2053

41. Heise, T., Pieber, T. R., Danne, T., Erichsen, L., \& Haahr, H. (2017). A Pooled Analysis of Clinical Pharmacology Trials Investigating the Pharmacokinetic and Pharmacodynamic Characteristics of Fast-Acting Insulin Aspart in Adults with Type 1 Diabetes. Clinical pharmacokinetics, 56(5), 551-559. doi:10.1007/s40262017-0514-8

42. Heise, T., Pieber, T. R., Danne, T., Erichsen, L., \& Haahr, H. (2017). A Pooled Analysis of Clinical Pharmacology Trials Investigating the Pharmacokinetic and Pharmacodynamic Characteristics of Fast-Acting Insulin Aspart in Adults with Type 1 Diabetes. Clin Pharmacokinet, 56(5), 551-559. doi:10.1007/s40262-0170514-8

43. Mathieu, C., Gillard, P., \& Benhalima, K. (2017). Insulin analogues in type 1 diabetes mellitus: getting better all the time. Nature Reviews Endocrinology, 13, 385. doi:10.1038/nrendo.2017.39

44. Gupta, S., Chattopadhyay, T., Pal Singh, M., \& Surolia, A. (2010).

Supramolecular insulin assembly II for a sustained treatment of type 1 diabetes mellitus. Proceedings of the National Academy of Sciences, 107(30), 1324613251. doi:10.1073/pnas.1005704107

45. Owens, D. R., Matfin, G., \& Monnier, L. (2014). Basal insulin analogues in the management of diabetes mellitus: what progress have we made?

Diabetes/Metabolism Research and Reviews, 30(2), 104-119. doi:doi:10.1002/dmrr.2469

46. Rosenstock, J., Schwartz, S. L., Clark, C. M., Park, G. D., Donley, D. W., \& Edwards, M. B. (2001). Basal Insulin Therapy in Type 2 Diabetes. 28-week comparison of insulin glargine (HOE 901) and NPH insulin, 24(4), 631-636. doi:10.2337/diacare.24.4.631 
47. Rosenstock, J., Dailey, G., Massi-Benedetti, M., Fritsche, A., Lin, Z., \& Salzman, A. (2005). Reduced Hypoglycemia Risk With Insulin Glargine. A meta-analysis comparing insulin glargine with human NPH insulin in type 2 diabetes, 28(4), 950-955. doi:10.2337/diacare.28.4.950

48. Poon, K., \& King, A. B. (2010). Glargine and detemir: Safety and efficacy profiles of the long-acting basal insulin analogs. Drug, healthcare and patient safety, 2, 213-223. doi:10.2147/DHPS.S7301

49. Pollom, R. K., Costigan, T., Lacaya, L. B., Ilag, L. L., \& Hollander, P. A. (2018). Similar Efficacy and Safety of Basaglar((R)) and Lantus((R)) in Patients with Type 2 Diabetes in Age Groups ( $<65$ Years, $>/=65$ Years): A Post Hoc Analysis from the ELEMENT-2 Study. Diabetes Ther, 9(2), 827-837. doi:10.1007/s13300018-0405-5

50. Home, P., Bartley, P., Russell-Jones, D., Hanaire-Broutin, H., Heeg, J.-E., Abrams, P., Landin-Olsson, M., Hylleberg, B., Lang, H., \& Draeger, E. (2004). Insulin Detemir Offers Improved Glycemic Control Compared With NPH Insulin in People With Type 1 Diabetes. A randomized clinical trial, 27(5), 1081-1087. doi:10.2337/diacare.27.5.1081

51. Swinnen, S. G., Simon, A. C., Holleman, F., Hoekstra, J. B., \& Devries, J. H. (2011). Insulin detemir versus insulin glargine for type 2 diabetes mellitus. Cochrane Database Syst Rev(7), Cd006383. doi:10.1002/14651858.CD006383.pub2

52. Raskin, P., Gylvin, T., Weng, W., \& Chaykin, L. (2009). Comparison of insulin detemir and insulin glargine using a basal-bolus regimen in a randomized, controlled clinical study in patients with type 2 diabetes. Diabetes Metab Res Rev, 25(6), 542-8. doi:10.1002/dmrr.989

53. Heise, T., Nosek, L., Ronn, B. B., Endahl, L., Heinemann, L., Kapitza, C., \& Draeger, E. (2004). Lower within-subject variability of insulin detemir in comparison to NPH insulin and insulin glargine in people with type 1 diabetes. Diabetes, 53(6), 1614-20.

54. Albright, E. S., Desmond, R., \& Bell, D. S. H. (2004). Efficacy of Conversion From Bedtime NPH Insulin Injection to Once- or Twice-Daily Injections of Insulin Glargine in Type 1 Diabetic Patients Using Basal/Bolus Therapy. Diabetes Care, 27(2), 632-633. doi:10.2337/diacare.27.2.632

55. Standl, E., \& Owen, D. R. (2016). New Long-Acting Basal Insulins: Does Benefit Outweigh Cost? Diabetes Care, 39(Supplement 2), S172-S179. doi: $10.2337 / \mathrm{dcS} 15-3011$

56. George, C. M., Byun, A., \& Howard-Thompson, A. (2018). New Injectable Agents for the Treatment of Type 2 Diabetes Part 1 - Injectable Insulins. The 
American Journal of Medicine, 131(7), 752-754.

doi:https://doi.org/10.1016/j.amjmed.2018.01.049

57. Bergenstal, R. M., Bailey, T. S., Rodbard, D., Ziemen, M., Guo, H., MuehlenBartmer, I., \& Ahmann, A. J. (2017). Comparison of Insulin Glargine 300 Units/mL and 100 Units/mL in Adults With Type 1 Diabetes: Continuous Glucose Monitoring Profiles and Variability Using Morning or Evening Injections. Diabetes Care, 40(4), 554-560. doi:10.2337/dc16-0684

58. Becker, R. H., Dahmen, R., Bergmann, K., Lehmann, A., Jax, T., \& Heise, T. (2015). New insulin glargine 300 Units . $\mathrm{mL}-1$ provides a more even activity profile and prolonged glycemic control at steady state compared with insulin glargine 100 Units . mL-1. Diabetes Care, 38(4), 637-43. doi:10.2337/dc14-0006

59. Vora, J., Cariou, B., Evans, M., Gross, J. L., Harris, S., Landstedt-Hallin, L., Mithal, A., Rodriguez, M. R., \& Meneghini, L. (2015). Clinical use of insulin degludec. Diabetes Res Clin Pract, 109(1), 19-31.

doi:10.1016/j.diabres.2015.04.002

60. Standl, E., \& Owen, D. R. (2016). New Long-Acting Basal Insulins: Does Benefit Outweigh Cost? Diabetes Care, 39 Suppl 2, S172-9. doi:10.2337/dcS15-3011

61. Heise, T., Hermanski, L., Nosek, L., Feldman, A., Rasmussen, S., \& Haahr, H. (2012). Insulin degludec: four times lower pharmacodynamic variability than insulin glargine under steady-state conditions in type 1 diabetes. Diabetes, Obesity and Metabolism, 14(9), 859-864. doi:doi:10.1111/j.14631326.2012.01627.x

62. Ratner, R. E., Gough, S. C. L., Mathieu, C., Del Prato, S., Bode, B., Mersebach, H., Endahl, L., \& Zinman, B. (2013). Hypoglycaemia risk with insulin degludec compared with insulin glargine in type 2 and type 1 diabetes: a pre-planned metaanalysis of phase 3 trials. Diabetes, Obesity and Metabolism, 15(2), 175-184. doi:doi:10.1111/dom.12032

63. Kadowaki, T., Jinnouchi, H., Kaku, K., Hersløv, M. L., Hyllested-Winge, J., \& Nakamura, S. (2016). Efficacy and safety of once-daily insulin degludec dosed flexibly at convenient times vs fixed dosing at the same time each day in a Japanese cohort with type 2 diabetes: A randomized, 26-week, treat-to-target trial. Journal of Diabetes Investigation, 7(5), 711-717. doi:doi:10.1111/jdi.12502

64. Mathieu, C., Hollander, P., Miranda-Palma, B., Cooper, J., Franek, E., RussellJones, D., Larsen, J., Tamer, S. C., Bain, S. C., \& Investigators, N. N. T. (2013). Efficacy and safety of insulin degludec in a flexible dosing regimen vs insulin glargine in patients with type 1 diabetes (BEGIN: Flex T1): a 26-week randomized, treat-to-target trial with a 26-week extension. The Journal of clinical endocrinology and metabolism, 98(3), 1154-1162. doi:10.1210/jc.2012-3249 
65. Maiorino, M. I., Bellastella, G., Esposito, K., \& Giugliano, D. (2017). Premixed insulin regimens in type 2 diabetes: pros. Endocrine, 55(1), 45-50.

doi:10.1007/s12020-016-0917-6

66. Garber, A. J. (2006). Premixed Insulin Analogues for the Treatment of Diabetes Mellitus. Drugs, 66(1), 31-49. doi:10.2165/00003495-200666010-00003

67. Allé, N. Ryzodeg® provides successful glycaemic control with fewer injections than a basal-bolus regimen.

68. Kurtzhals, P., Schäffer, L., Sørensen, A., Kristensen, C., Jonassen, I., Schmid, C., $\&$ Trüb, T. (2000). Correlations of receptor binding and metabolic and mitogenic potencies of insulin analogs designed for clinical use. Diabetes, 49(6), 999-1005. doi:10.2337/diabetes.49.6.999

69. De Meyts, P. (2015). Insulin/receptor binding: The last piece of the puzzle? BioEssays, 37(4), 389-397. doi:doi:10.1002/bies.201400190

70. Nielsen, L., Frokjaer, S., Brange, J., Uversky, V. N., \& Fink, A. L. (2001). Probing the Mechanism of Insulin Fibril Formation with Insulin Mutants. Biochemistry, 40(28), 8397-8409. doi:10.1021/bi0105983

71. Ivanova, M. I., Sievers, S. A., Sawaya, M. R., Wall, J. S., \& Eisenberg, D. (2009). Molecular basis for insulin fibril assembly. Proceedings of the National Academy of Sciences, 106(45), 18990-18995. doi:10.1073/pnas.0910080106

72. Schlein, M. (2017). Insulin Formulation Characterization-the Thioflavin T Assays. The AAPS Journal, 19(2), 397-408. doi:10.1208/s12248-016-0028-6

73. Yang, Y., Petkova, A., Huang, K., Xu, B., Hua, Q.-X., Ye, I.-J., Chu, Y.-C., Hu, S.-Q., Phillips, N. B., Whittaker, J., Ismail-Beigi, F., Mackin, R. B., Katsoyannis, P. G., Tycko, R., \& Weiss, M. A. (2010). An Achilles' Heel in an Amyloidogenic Protein and Its Repair: INSULIN FIBRILLATION AND THERAPEUTIC DESIGN. Journal of Biological Chemistry, 285(14), 10806-10821. doi:10.1074/jbc.M109.067850

74. Frankær, C. G., Sønderby, P., Bang, M. B., Mateiu, R. V., Groenning, M., Bukrinski, J., \& Harris, P. (2017). Insulin fibrillation: The influence and coordination of Zn2+. Journal of Structural Biology, 199(1), 27-38. doi:https://doi.org/10.1016/j.jsb.2017.05.006

75. Haahr, H., \& Heise, T. (2014). A review of the pharmacological properties of insulin degludec and their clinical relevance. Clinical pharmacokinetics, 53(9), 787-800. doi:10.1007/s40262-014-0165-y

76. Jonassen, I., Havelund, S., Hoeg-Jensen, T., Steensgaard, D. B., Wahlund, P.-O., \& Ribel, U. (2012). Design of the novel protraction mechanism of insulin 
degludec, an ultra-long-acting basal insulin. Pharmaceutical research, 29(8), 2104-2114. doi:10.1007/s11095-012-0739-z

77. Becker, R. H. A., Frick, A. D., Teichert, L., Nosek, L., Heinemann, L., Heise, T., $\&$ Rave, K. (2008). Fluctuation and reproducibility of exposure and effect of insulin glargine in healthy subjects*. Diabetes, Obesity and Metabolism, 10(11), 1105-1113. doi:doi:10.1111/j.1463-1326.2008.00874.x

78. $(2018,11 / 2018)$. Humulin ${ }^{\circledR N}$ Package Insert. Retrieved from https://www.accessdata.fda.gov/drugsatfda_docs/label/2018/018781s181lbl.pdf

79. (2018, 06/2018). Novolin®N Package Insert. Retrieved from https://www.accessdata.fda.gov/drugsatfda_docs/label/2018/019959s074s079lbl.p df

80. $\quad(2018,11 / 2018)$. Lantus ${ }^{\circledR}$ Package Insert.

81. (2018, 11/2018). Basaglar® Package Insert. Retrieved from https://www.accessdata.fda.gov/drugsatfda_docs/label/2018/205692s019lbl.pdf

82. (2019). Levemir® Package Insert. Retrieved from https://www.accessdata.fda.gov/drugsatfda_docs/label/2019/021536s054lbl.pdf

83. $(2018,10 / 2018)$. Toujeo ${ }^{\circledR}$ Package Insert. Retrieved from https://www.accessdata.fda.gov/drugsatfda_docs/label/2018/206538s010s011lbl.p df

84. $\quad(2018,11 / 2018)$. Tresiba ${ }^{\circledR}$ Package Insert. Retrieved from https://www.accessdata.fda.gov/drugsatfda_docs/label/2018/203314s010lbl.pdf

85. Selam, J.-L. (2010). Evolution of diabetes insulin delivery devices. Journal of diabetes science and technology, 4(3), 505-513.

doi:10.1177/193229681000400302

86. Lteif, A. N., \& Schwenk, W. F. (1999). Accuracy of pen injectors versus insulin syringes in children with type 1 diabetes. Diabetes Care, 22(1), 137-40.

87. Guo, X., \& Wang, W. (2017). Challenges and recent advances in the subcutaneous delivery of insulin. Expert Opin Drug Deliv, 14(6), 727-734. doi: $10.1080 / 17425247.2016 .1232247$

88. Engwerda, E. E., Abbink, E. J., Tack, C. J., \& de Galan, B. E. (2011). Improved pharmacokinetic and pharmacodynamic profile of rapid-acting insulin using needle-free jet injection technology. Diabetes Care, 34(8), 1804-8. doi:10.2337/dc11-0182

89. Guo, L., Xiao, X., Sun, X., \& Qi, C. (2017). Comparison of jet injector and insulin pen in controlling plasma glucose and insulin concentrations in type 2 
diabetic patients. Medicine, 96(1), e5482-e5482.

doi:10.1097/MD.0000000000005482

90. Engwerda, E. E., Tack, C. J., \& de Galan, B. E. (2013). Needle-free jet injection of rapid-acting insulin improves early postprandial glucose control in patients with diabetes. Diabetes Care, 36(11), 3436-41. doi:10.2337/dc13-0492

91. Karges, B., Schwandt, A., Heidtmann, B., Kordonouri, O., Binder, E., Schierloh, U., Boettcher, C., Kapellen, T., Rosenbauer, J., \& Holl, R. W. (2017). Association of Insulin Pump Therapy vs Insulin Injection Therapy With Severe Hypoglycemia, Ketoacidosis, and Glycemic Control Among Children, Adolescents, and Young Adults With Type 1 Diabetes. JAMA, 318(14), 13581366. doi:10.1001/jama.2017.13994

92. Aronson, R., Reznik, Y., Conget, I., Castañeda, J. A., Runzis, S., Lee, S. W., Cohen, O., \& Op, T. m. S. G. (2016). Sustained efficacy of insulin pump therapy compared with multiple daily injections in type 2 diabetes: 12-month data from the OpT2mise randomized trial. Diabetes, obesity \& metabolism, 18(5), 500-507. doi:10.1111/dom.12642

93. PARKES, A. S., \& YOUNG, F. G. (1939). THE INFLUENCE OF THE SUBCUTANEOUS IMPLANTATION OF TABLETS OF SOLID INSULIN ON THE BLOOD SUGAR LEVEL OF THE RABBIT. 1(1), 108. doi:10.1677/joe.0.0010108

94. Davis, B. K. (1972). Control of diabetes with polyacrylamide implants containing insulin. Experientia, 28(3), 348-348. doi:10.1007/bf01928732

95. Creque, H. M., Langer, R., \& Folkman, J. (1980). One Month of Sustained Release of Insulin from a Polymer Implant. Diabetes, 29(1), 37-40. doi:10.2337/diab.29.1.37

96. Stevenson, R. W., Patel, H. M., Parsons, J. A., \& Ryman, B. E. (1982). Prolonged hypoglycemic effect in diabetic dogs due to subcutaneous administration of insulin in liposomes. Diabetes, 31(6 Pt 1), 506-11.

97. Goosen, M. F. A., Leung, Y. F., Chou, S., \& Sun, A. M. (1982). Insulin-Albumin Microbeads: An Implantable, Biodegradable System. Biomaterials, Medical Devices, and Artificial Organs, 10(3), 205-218. doi:10.3109/10731198209118781

98. Goosen, M. F., Leung, Y. F., O'Shea, G. M., Chou, S., \& Sun, A. M. (1983). Slow release of insulin from a biodegradable matrix implanted in diabetic rats. Diabetes, 32(5), 478-81.

99. Lin, S. Y., Ho, L. T., \& Chiou, H. L. (1985). Microencapsulation and controlled release of insulin from polylactic acid microcapsules. Biomater Med Devices Artif Organs, 13(3-4), 187-201. 
100. Lin, S. Y., Ho, L. T., \& Chiou, H. L. (1988). Insulin controlled-release microcapsules to prolong the hypoglycemic effect in diabetic rats. Biomater Artif Cells Artif Organs, 16(4), 815-28.

101. Patel, A., Cholkar, K., \& Mitra, A. K. (2014). Recent developments in protein and peptide parenteral delivery approaches. Therapeutic delivery, 5(3), 337-365. doi:10.4155/tde.14.5

102. Vaishya, R., Khurana, V., Patel, S., \& Mitra, A. K. (2015). Long-term delivery of protein therapeutics. Expert opinion on drug delivery, 12(3), 415-440. doi: $10.1517 / 17425247.2015 .961420$

103. Zhang, Y. M., Yang, F., Yang, Y. Q., Song, F. L., \& Xu, A. L. (2008). Recombinant interferon-alpha2b poly(lactic-co-glycolic acid) microspheres: pharmacokinetics-pharmacodynamics study in rhesus monkeys following intramuscular administration. Acta Pharmacol Sin, 29(11), 1370-5. doi:10.1111/j.1745-7254.2008.00881.x

104. Hossain, K. M. Z., Patel, U., \& Ahmed, I. (2014). Development of microspheres for biomedical applications: a review. Progress in biomaterials, 4(1), 1-19. doi:10.1007/s40204-014-0033-8

105. Qi, F., Wu, J., Li, H., \& Ma, G. (2018). Recent research and development of PLGA/PLA microspheres/nanoparticles: A review in scientific and industrial aspects. Frontiers of Chemical Science and Engineering. doi:10.1007/s11705018-1729-4

106. Ansary, R. H., Rahman, M. M., Awang, M. B., Katas, H., Hadi, H., \& Doolaanea, A. A. (2016). Preparation, characterization, and in vitro release studies of insulinloaded double-walled poly(lactide-co-glycolide) microspheres. Drug Delivery and Translational Research, 6(3), 308-318. doi:10.1007/s13346-016-0278-y

107. Naha, P. C., Kanchan, V., \& Panda, A. K. (2009). Evaluation of parenteral depot insulin formulation using PLGA and PLA microparticles. J Biomater Appl, 24(4), 309-25. doi:10.1177/0885328208096238

108. Sheshala, R., Peh, K. K., \& Darwis, Y. (2009). Preparation, characterization, and in vivo evaluation of insulin-loaded PLA-PEG microspheres for controlled parenteral drug delivery. Drug Dev Ind Pharm, 35(11), 1364-74. doi:10.3109/03639040902939213

109. Ye, M., Kim, S., \& Park, K. (2010). Issues in long-term protein delivery using biodegradable microparticles. Journal of Controlled Release, 146(2), 241-260. doi:https://doi.org/10.1016/j.jconrel.2010.05.011

110. Schoubben, A., Blasi, P., Giovagnoli, S., Perioli, L., Rossi, C., \& Ricci, M. (2009). Novel composite microparticles for protein stabilization and delivery. 
European Journal of Pharmaceutical Sciences, 36(2), 226-234.

doi:https://doi.org/10.1016/j.ejps.2008.09.008

111. Bao, W., Zhou, J., Luo, J., \& Wu, D. (2006). PLGA microspheres with high drug loading and high encapsulation efficiency prepared by a novel solvent evaporation technique. Journal of Microencapsulation, 23(5), 471-479.

doi:10.1080/02652040600687613

112. Han, Y., Tian, H., He, P., Chen, X., \& Jing, X. (2009). Insulin nanoparticle preparation and encapsulation into poly(lactic-co-glycolic acid) microspheres by using an anhydrous system. International Journal of Pharmaceutics, 378(1), 159166. doi:https://doi.org/10.1016/j.ijpharm.2009.05.021

113. Wu, C., van de Weert, M., Baldursdottir, S. G., Yang, M., \& Mu, H. (2018). Effect of excipients on encapsulation and release of insulin from spray-dried solid lipid microparticles. International Journal of Pharmaceutics, 550(1), 439-446. doi:https://doi.org/10.1016/j.ijpharm.2018.09.007

114. Park, W., Kim, D., Kang, H. C., Bae, Y. H., \& Na, K. (2012). Multi-arm histidine copolymer for controlled release of insulin from poly(lactide-co-glycolide) microsphere. Biomaterials, 33(34), 8848-8857. doi:https://doi.org/10.1016/j.biomaterials.2012.08.042

115. Manoharan, C., \& Singh, J. (2013). Evaluation of poly (1, 6-bis-(pcarboxyphenoxy) hexane-co-sebacic acid microspheres for controlled basal insulin delivery. Pharm Res, 30(3), 627-40. doi:10.1007/s11095-012-0880-8

116. Ma, G. (2014). Microencapsulation of protein drugs for drug delivery: Strategy, preparation, and applications. Journal of Controlled Release, 193, 324-340. doi:https://doi.org/10.1016/j.jconrel.2014.09.003

117. Iqbal, M., Zafar, N., Fessi, H., \& Elaissari, A. (2015). Double emulsion solvent evaporation techniques used for drug encapsulation. International Journal of Pharmaceutics, 496(2), 173-190. doi:https://doi.org/10.1016/j.ijpharm.2015.10.057

118. Manoharan, C., \& Singh, J. (2015). Addition of Zinc Improves the Physical Stability of Insulin in the Primary Emulsification Step of the Poly(lactide-coglycolide) Microsphere Preparation Process. Polymers, 7(5), 836.

119. Manoharan, C., \& Singh, J. (2009). Insulin loaded PLGA microspheres: effect of zinc salts on encapsulation, release, and stability. J Pharm Sci, 98(2), 529-42. doi:10.1002/jps.21445

120. Taluja, A., \& Bae, Y. H. (2007). Role of a novel excipient poly(ethylene glycol)b-poly(L-histidine) in retention of physical stability of insulin at aqueous/organic interface. Mol Pharm, 4(4), 561-70. doi:10.1021/mp060120z 
121. Takenaga, M., Yamaguchi, Y., Kitagawa, A., Ogawa, Y., Mizushima, Y., \& Igarashi, R. (2002). A novel sustained-release formulation of insulin with dramatic reduction in initial rapid release. J Control Release, 79(1-3), 81-91.

122. Kang, F., \& Singh, J. (2005). Preparation, in vitro release, in vivo absorption and biocompatibility studies of insulin-loaded microspheres in rabbits. AAPS

PharmSciTech, 6(3), E487-E494. doi:10.1208/pt060361

123. Manoharan, C., \& Singh, J. (2009). Evaluation of polyanhydride microspheres for basal insulin delivery: Effect of copolymer composition and zinc salt on encapsulation, in vitro release, stability, in vivo absorption and bioactivity in diabetic rats. $J$ Pharm Sci, 98(11), 4237-50. doi:10.1002/jps.21741

124. Presmanes, C., de Miguel, L., Espada, R., Alvarez, C., Morales, E., \& Torrado, J. J. (2011). Effect of PLGA hydrophilia on the drug release and the hypoglucemic activity of different insulin-loaded PLGA microspheres. J Microencapsul, 28(8), 791-8. doi:10.3109/02652048.2011.621554

125. Takenaga, M., Yamaguchi, Y., Ogawa, Y., Kitagawa, A., Kawai, S., Mizushima, Y., Igarashi, R., Namae, M., \& Komeda, K. (2006). Administration of optimum sustained-insulin release PLGA microcapsules to spontaneous diabetes-prone BB/Wor//Tky rats. Drug Deliv, 13(2), 149-57. doi:10.1080/10717540500315989

126. Shenoy, D. B., D'Souza, R. J., Tiwari, S. B., \& Udupa, N. (2003). Potential Applications of Polymeric Microsphere Suspension as Subcutaneous Depot for Insulin. Drug Development and Industrial Pharmacy, 29(5), 555-563. doi:10.1081/DDC-120018644

127. Yamaguchi, Y., Takenaga, M., Kitagawa, A., Ogawa, Y., Mizushima, Y., \& Igarashi, R. (2002). Insulin-loaded biodegradable PLGA microcapsules: initial burst release controlled by hydrophilic additives. Journal of Controlled Release, 81(3), 235-249. doi:https://doi.org/10.1016/S0168-3659(02)00060-3

128. Wu, J.-Z., Williams, G. R., Li, H.-Y., Wang, D.-X., Li, S.-D., \& Zhu, L.-M. (2017). Insulin-loaded PLGA microspheres for glucose-responsive release. Drug Delivery, 24(1), 1513-1525. doi:10.1080/10717544.2017.1381200

129. Paillard-Giteau, A., Tran, V. T., Thomas, O., Garric, X., Coudane, J., Marchal, S., Chourpa, I., Benoît, J. P., Montero-Menei, C. N., \& Venier-Julienne, M. C. (2010). Effect of various additives and polymers on lysozyme release from PLGA microspheres prepared by an s/o/w emulsion technique. European Journal of Pharmaceutics and Biopharmaceutics, 75(2), 128-136. doi:https://doi.org/10.1016/j.ejpb.2010.03.005

130. Andhariya, J. V., Shen, J., Choi, S., Wang, Y., Zou, Y., \& Burgess, D. J. (2017). Development of in vitro-in vivo correlation of parenteral naltrexone loaded polymeric microspheres. Journal of Controlled Release, 255, 27-35. doi:https://doi.org/10.1016/j.jconrel.2017.03.396 
131. Garner, J., Skidmore, S., Park, H., Park, K., Choi, S., \& Wang, Y. (2018). Beyond Q1/Q2: The Impact of Manufacturing Conditions and Test Methods on Drug Release From PLGA-Based Microparticle Depot Formulations. Journal of Pharmaceutical Sciences, 107(1), 353-361. doi:https://doi.org/10.1016/j.xphs.2017.10.027

132. Giunchedi, P., Conti, B., Genta, I., Conte, U., \& Puglisi, G. (2001). Emulsion Spray-Drying for the Preparation of Albumin-Loaded PLGA Microspheres. Drug Development and Industrial Pharmacy, 27(7), 745-750. doi:10.1081/DDC100107331

133. Quaglia, F., De Rosa, G., Granata, E., Ungaro, F., Fattal, E., \& Immacolata La Rotonda, M. (2003). Feeding liquid, non-ionic surfactant and cyclodextrin affect the properties of insulin-loaded poly(lactide-co-glycolide) microspheres prepared by spray-drying. Journal of Controlled Release, 86(2), 267-278. doi:https://doi.org/10.1016/S0168-3659(02)00414-5

134. Zhang, H., Pu, C., Wang, Q., Tan, X., Gou, J., He, H., Zhang, Y., Yin, T., Wang, Y., \& Tang, X. (2018). Physicochemical Characterization and Pharmacokinetics of Agomelatine-Loaded PLGA Microspheres for Intramuscular Injection. Pharmaceutical Research, 36(1), 9. doi:10.1007/s11095-018-2538-7

135. Mao, S., Xu, J., Cai, C., Germershaus, O., Schaper, A., \& Kissel, T. (2007). Effect of WOW process parameters on morphology and burst release of FITC-dextran loaded PLGA microspheres. International Journal of Pharmaceutics, 334(1), 137-148. doi:https://doi.org/10.1016/j.ijpharm.2006.10.036

136. Shi, Y., Ma, S., Tian, R., Zhao, Y., Cai, F., Li, R., \& Shang, Q. (2016). Manufacture, Characterization, and Release Profiles of Insulin-Loaded Mesoporous PLGA Microspheres. Materials and Manufacturing Processes, 31(8), 1061-1065. doi:10.1080/10426914.2014.984219

137. Wu, L., Janagam, D. R., Mandrell, T. D., Johnson, J. R., \& Lowe, T. L. (2015). Long-acting injectable hormonal dosage forms for contraception. Pharm Res, 32(7), 2180-91. doi:10.1007/s11095-015-1686-2

138. Hamishehkar, H., Emami, J., Najafabadi, A. R., Gilani, K., Minaiyan, M., Mahdavi, H., \& Nokhodchi, A. (2009). The effect of formulation variables on the characteristics of insulin-loaded poly(lactic-co-glycolic acid) microspheres prepared by a single phase oil in oil solvent evaporation method. Colloids and Surfaces B: Biointerfaces, 74(1), 340-349. doi:https://doi.org/10.1016/j.colsurfb.2009.08.003

139. Makadia, H. K., \& Siegel, S. J. (2011). Poly Lactic-co-Glycolic Acid (PLGA) as Biodegradable Controlled Drug Delivery Carrier. Polymers, 3(3), 1377-1397. doi:10.3390/polym3031377 
140. Zhong, H., Chan, G., Hu, Y., Hu, H., \& Ouyang, D. (2018). A Comprehensive Map of FDA-Approved Pharmaceutical Products. Pharmaceutics, 10(4). doi:10.3390/pharmaceutics10040263

141. Carracher, A. M., Marathe, P. H., \& Close, K. L. (2017). American Association of Diabetes Educators 2017. Journal of diabetes, 9(12), 1054-1057.

142. AntraBio. (2017). AntraBio Q2 2017. Retrieved from http://content.stockpr.com/antriabio/media/09c18ff44812774898762bc9fc51424a. pdf

143. Wu, L., Janagam, D. R., Mandrell, T. D., Johnson, J. R., \& Lowe, T. L. (2015). Long-Acting Injectable Hormonal Dosage Forms for Contraception. Pharmaceutical Research, 32(7), 2180-2191. doi:10.1007/s11095-015-1686-2

144. Packhaeuser, C. B., Schnieders, J., Oster, C. G., \& Kissel, T. (2004). In situ forming parenteral drug delivery systems: an overview. European Journal of Pharmaceutics and Biopharmaceutics, 58(2), 445-455. doi:https://doi.org/10.1016/j.ejpb.2004.03.003

145. Hatefi, A., \& Amsden, B. (2002). Biodegradable injectable in situ forming drug delivery systems. Journal of Controlled Release, 80(1), 9-28. doi:https://doi.org/10.1016/S0168-3659(02)00008-1

146. Agarwal, P., \& Rupenthal, I. D. (2013). Injectable implants for the sustained release of protein and peptide drugs. Drug Discovery Today, 18(7), 337-349. doi:https://doi.org/10.1016/j.drudis.2013.01.013

147. Kempe, S., \& Mäder, K. (2012). In situ forming implants — an attractive formulation principle for parenteral depot formulations. Journal of Controlled Release, 161(2), 668-679. doi:https://doi.org/10.1016/j.jconrel.2012.04.016

148. Janagam, D., Wang, L., Ananthula, S., Johnson, J., \& Lowe, T. (2016). An Accelerated Release Study to Evaluate Long-Acting Contraceptive Levonorgestrel-Containing in Situ Forming Depot Systems. Pharmaceutics, 8(3), 28.

149. He, S., J. Yaszemski, M., Yasko, A. W., Engel, P. S., \& Mikos, A. G. (2000). Injectable biodegradable polymer composites based on poly(propylene fumarate) crosslinked with poly(ethylene glycol)-dimethacrylate. Biomaterials, 21(23), 2389-2394. doi:https://doi.org/10.1016/S0142-9612(00)00106-X

150. Lu, S., \& Anseth, K. S. (1999). Photopolymerization of multilaminated poly(HEMA) hydrogels for controlled release. Journal of Controlled Release, 57(3), 291-300. doi:https://doi.org/10.1016/S0168-3659(98)00125-4

151. Chiu, Y.-L., Chen, S.-C., Su, C.-J., Hsiao, C.-W., Chen, Y.-M., Chen, H.-L., \& Sung, H.-W. (2009). pH-triggered injectable hydrogels prepared from aqueous N- 
palmitoyl chitosan: In vitro characteristics and in vivo biocompatibility. Biomaterials, 30(28), 4877-4888.

doi:https://doi.org/10.1016/j.biomaterials.2009.05.052

152. Vaghani, S. S., \& Patel, M. M. (2011). Hydrogels based on interpenetrating network of chitosan and polyvinyl pyrrolidone for $\mathrm{pH}$-sensitive delivery of repaglinide. Curr Drug Discov Technol, 8(2), 126-35.

153. Oak, M., \& Singh, J. (2012). Chitosan-zinc-insulin complex incorporated thermosensitive polymer for controlled delivery of basal insulin in vivo. $J$ Control Release, 163(2), 145-53. doi:10.1016/j.jconrel.2012.07.035

154. Janagam, D. R., Ananthula, S., Chaudhry, K., Wu, L., Mandrell, T. D., Johnson, J. R., \& Lowe, T. L. (2017). Injectable In Situ Forming Depot Systems for LongActing Contraception. Advanced Biosystems, 1(10), 1700097. doi:doi:10.1002/adbi.201700097

155. Khaled, A.-T., \& Jagdish, S. (2007). Smart Polymer Based Delivery Systems for Peptides and Proteins. Recent Patents on Drug Delivery \& Formulation, 1(1), 6571. doi:http://dx.doi.org/10.2174/187221107779814113

156. Al-Tahami, K., \& Singh, J. (2007). Smart polymer based delivery systems for peptides and proteins. Recent Pat Drug Deliv Formul, 1(1), 65-71.

157. Barichello, J. M., Morishita, M., Takayama, K., \& Nagai, T. (1999). Absorption of insulin from Pluronic F-127 gels following subcutaneous administration in rats. International Journal of Pharmaceutics, 184(2), 189-198. doi:https://doi.org/10.1016/S0378-5173(99)00119-2

158. Chung, T.-W., Liu, D.-Z., \& Yang, J.-S. (2010). Effects of interpenetration of thermo-sensitive gels by crosslinking of chitosan on nasal delivery of insulin: In vitro characterization and in vivo study. Carbohydrate Polymers, 82(2), 316-322. doi:https://doi.org/10.1016/j.carbpol.2010.04.068

159. Yang, G., Wang, Q., Gao, Y., Yang, C., \& Hu, L. (2018). Combination of coating and injectable hydrogel depot to improve the sustained delivery of insulin.

Journal of Drug Delivery Science and Technology, 45, 415-421. doi:https://doi.org/10.1016/j.jddst.2018.03.028

160. Cho, H., Gao, J., \& Kwon, G. S. (2016). PEG-b-PLA micelles and PLGA-b-PEGb-PLGA sol-gels for drug delivery. Journal of controlled release : official journal of the Controlled Release Society, 240, 191-201. doi:10.1016/j.jconrel.2015.12.015

161. Kim, Y. J., Choi, S., Koh, J. J., Lee, M., Ko, K. S., \& Kim, S. W. (2001). Controlled release of insulin from injectable biodegradable triblock copolymer. Pharm Res, 18(4), 548-50. 
162. Choi, S., \& Kim, S. W. (2003). Controlled release of insulin from injectable biodegradable triblock copolymer depot in ZDF rats. Pharm Res, 20(12), 200810.

163. Al-Tahami, K., Oak, M., Mandke, R., \& Singh, J. (2011). Basal level insulin delivery: in vitro release, stability, biocompatibility, and in vivo absorption from thermosensitive triblock copolymers. J Pharm Sci, 100(11), 4790-803. doi:10.1002/jps.22685

164. Huynh, D. P., Nguyen, M. K., Pi, B. S., Kim, M. S., Chae, S. Y., Lee, K. C., Kim, B. S., Kim, S. W., \& Lee, D. S. (2008). Functionalized injectable hydrogels for controlled insulin delivery. Biomaterials, 29(16), 2527-2534. doi:https://doi.org/10.1016/j.biomaterials.2008.02.016

165. Mansouri, S., Lavigne, P., Corsi, K., Benderdour, M., Beaumont, E., \& Fernandes, J. C. (2004). Chitosan-DNA nanoparticles as non-viral vectors in gene therapy: strategies to improve transfection efficacy. Eur J Pharm Biopharm, $57(1), 1-8$.

166. Huynh, D. P., Nguyen, M. K., Pi, B. S., Kim, M. S., Chae, S. Y., Lee, K. C., Kim, B. S., Kim, S. W., \& Lee, D. S. (2008). Functionalized injectable hydrogels for controlled insulin delivery. Biomaterials, 29(16), 2527-34.

doi:10.1016/j.biomaterials.2008.02.016

167. Nguyen, M. K., \& Lee, D. S. (2010). Bioadhesive PAA-PEG-PAA triblock copolymer hydrogels for drug delivery in oral cavity. Macromolecular Research, 18(3), 284-288. doi:10.1007/s13233-010-0315-5

168. Jiang, H. L., Kim, Y. K., Lee, S. M., Park, M. R., Kim, E. M., Jin, Y. M., Arote, R., Jeong, H. J., Song, S. C., Cho, M. H., \& Cho, C. S. (2010). Galactosylated chitosan-g-PEI/DNA complexes-loaded poly(organophosphazene) hydrogel as a hepatocyte targeting gene delivery system. Arch Pharm Res, 33(4), 551-6. doi:10.1007/s12272-010-0409-9

169. Park, M.-R., Chun, C., Cho, C.-S., \& Song, S.-C. (2010). Enhancement of sustained and controlled protein release using polyelectrolyte complex-loaded injectable and thermosensitive hydrogel. European Journal of Pharmaceutics and Biopharmaceutics, 76(2), 179-188. doi:https://doi.org/10.1016/j.ejpb.2010.06.012

170. Ghasemi Tahrir, F., Ganji, F., Mani, A. R., \& Khodaverdi, E. (2016). In vitro and in vivo evaluation of thermosensitive chitosan hydrogel for sustained release of insulin. Drug Deliv, 23(3), 1038-46. doi:10.3109/10717544.2014.932861

171. Nguyen, M. K., Huynh, C. T., Gao, G. H., Kim, J. H., Huynh, D. P., Chae, S. Y., Lee, K. C., \& Lee, D. S. (2011). Biodegradable oligo(amidoamine/ $\beta$-amino ester) hydrogels for controlled insulin delivery. Soft Matter, 7(6), 2994-3001. doi: $10.1039 / \mathrm{COSM} 01285 \mathrm{H}$ 
172. Huynh, D. P., Im, G. J., Chae, S. Y., Lee, K. C., \& Lee, D. S. (2009). Controlled release of insulin from $\mathrm{pH} /$ temperature-sensitive injectable pentablock copolymer hydrogel. J Control Release, 137(1), 20-4. doi:10.1016/j.jconrel.2009.02.021

173. Jeong, Y., Joo, M. K., Bahk, K. H., Choi, Y. Y., Kim, H. T., Kim, W. K., Lee, H. J., Sohn, Y. S., \& Jeong, B. (2009). Enzymatically degradable temperaturesensitive polypeptide as a new in-situ gelling biomaterial. $J$ Control Release, 137(1), 25-30. doi:10.1016/j.jconrel.2009.03.008

174. Ravivarapu, H. B., Moyer, K. L., \& Dunn, R. L. (2000). Sustained activity and release of leuprolide acetate from an in situ forming polymeric implant. AAPS PharmSciTech, 1(1), 1-8. doi:10.1208/pt010101

175. Brodbeck, K. J., Pushpala, S., \& McHugh, A. J. (1999). Sustained release of human growth hormone from PLGA solution depots. Pharm Res, 16(12), 1825-9.

176. Kang, F., \& Singh, J. (2005). In vitro release of insulin and biocompatibility of in situ forming gel systems. International Journal of Pharmaceutics, 304(1), 83-90. doi:https://doi.org/10.1016/j.ijpharm.2005.07.024

177. Dhawan, S., Kapil, R., \& Kapoor, D. N. (2011). Development and Evaluation of In Situ Gel-forming System for Sustained Delivery of Insulin. Journal of Biomaterials Applications, 25(7), 699-720. doi:10.1177/0885328209359959

178. Anand, O., Almoazen, H., Mehrotra, N., Johnson, J., \& Shukla, A. (2012). Controlled release of modified insulin glargine from novel biodegradable injectable gels. AAPS PharmSciTech, 13(1), 313-322. doi:10.1208/s12249-0119744-5

179. Fu, M., Zhang, C., Dai, Y., Li, X., Pan, M., Huang, W., Qian, H., \& Ge, L. (2018). Injectable self-assembled peptide hydrogels for glucose-mediated insulin delivery. Biomater Sci, 6(6), 1480-1491. doi:10.1039/c8bm00006a

180. Solorio, L., Sundarapandiyan, D., Olear, A., \& Exner, A. A. (2015). The Effect of Additives on the Behavior of Phase Sensitive In Situ Forming Implants. Journal of Pharmaceutical Sciences, 104(10), 3471-3480. doi:doi:10.1002/jps.24558

181. Sun, Y., Jensen, H., Petersen, N. J., Larsen, S. W., \& Østergaard, J. (2017). Phase separation of in situ forming poly (lactide-co-glycolide acid) implants investigated using a hydrogel-based subcutaneous tissue surrogate and UV-vis imaging. Journal of Pharmaceutical and Biomedical Analysis, 145, 682-691. doi:https://doi.org/10.1016/j.jpba.2017.07.056

182. Madan, M., Bajaj, A., Lewis, S., Udupa, N., \& Baig, J. A. (2009). In situ forming polymeric drug delivery systems. Indian journal of pharmaceutical sciences, 71(3), 242-251. doi:10.4103/0250-474X.56015 
183. Patel, R. B., Solorio, L., Wu, H., Krupka, T., \& Exner, A. A. (2010). Effect of injection site on in situ implant formation and drug release in vivo. Journal of Controlled Release, 147(3), 350-358.

doi:https://doi.org/10.1016/j.jconrel.2010.08.020

184. Parent, M., Nouvel, C., Koerber, M., Sapin, A., Maincent, P., \& Boudier, A. (2013). PLGA in situ implants formed by phase inversion: Critical physicochemical parameters to modulate drug release. Journal of Controlled Release, 172(1), 292-304. doi:https://doi.org/10.1016/j.jconrel.2013.08.024

185. Akash, M. S. H., Rehman, K., \& Chen, S. (2014). Pluronic F127-Based Thermosensitive Gels for Delivery of Therapeutic Proteins and Peptides. Polymer Reviews, 54(4), 573-597. doi:10.1080/15583724.2014.927885

186. Shalaby, T. I., \& El-Refaie, W. M. (2018). Bioadhesive Chitosan-Coated Cationic Nanoliposomes With Improved Insulin Encapsulation and Prolonged Oral Hypoglycemic Effect in Diabetic Mice. Journal of Pharmaceutical Sciences, 107(8), 2136-2143. doi:https://doi.org/10.1016/j.xphs.2018.04.011

187. Sun, Y., Jensen, H., Petersen, N. J., Larsen, S. W., \& Østergaard, J. (2018). Concomitant monitoring of implant formation and drug release of in situ forming poly (lactide-co-glycolide acid) implants in a hydrogel matrix mimicking the subcutis using UV-vis imaging. Journal of Pharmaceutical and Biomedical Analysis, 150, 95-106. doi:https://doi.org/10.1016/j.jpba.2017.11.065

188. Gao, G. H., Park, M. J., Li, Y., Im, G. H., Kim, J.-H., Kim, H. N., Lee, J. W., Jeon, P., Bang, O. Y., Lee, J. H., \& Lee, D. S. (2012). The use of pH-sensitive positively charged polymeric micelles for protein delivery. Biomaterials, 33(35), 9157-9164. doi:https://doi.org/10.1016/j.biomaterials.2012.09.016

189. Janagam, D. R., Wu, L., \& Lowe, T. L. (2017). Nanoparticles for drug delivery to the anterior segment of the eye. Advanced Drug Delivery Reviews, 122, 31-64. doi:https://doi.org/10.1016/j.addr.2017.04.001

190. Sarmento, B., Ribeiro, A., Veiga, F., Sampaio, P., Neufeld, R., \& Ferreira, D. (2007). Alginate/Chitosan Nanoparticles are Effective for Oral Insulin Delivery. Pharmaceutical Research, 24(12), 2198-2206. doi:10.1007/s11095-007-9367-4

191. Mukhopadhyay, P., Chakraborty, S., Bhattacharya, S., Mishra, R., \& Kundu, P. P. (2015). pH-sensitive chitosan/alginate core-shell nanoparticles for efficient and safe oral insulin delivery. International Journal of Biological Macromolecules, 72, 640-648. doi:https://doi.org/10.1016/j.ijbiomac.2014.08.040

192. Sun, S., Liang, N., Yamamoto, H., Kawashima, Y., Cui, F., \& Yan, P. (2015). pHsensitive poly(lactide-co-glycolide) nanoparticle composite microcapsules for oral delivery of insulin. International journal of nanomedicine, 10, 3489-3498. doi:10.2147/IJN.S81715 
193. Packhaeuser, C. B., \& Kissel, T. (2007). On the design of in situ forming biodegradable parenteral depot systems based on insulin loaded dialkylaminoalkyl-amine-poly(vinyl alcohol)-g-poly(lactide-co-glycolide) nanoparticles. Journal of Controlled Release, 123(2), 131-140. doi:https://doi.org/10.1016/j.jconrel.2007.08.004

194. Fu, Y., \& Kao, W. J. (2010). Drug release kinetics and transport mechanisms of non-degradable and degradable polymeric delivery systems. Expert opinion on drug delivery, 7(4), 429-444. doi:10.1517/17425241003602259

195. Abdelkader, D. H., El-Gizawy, S. A., Faheem, A. M., McCarron, P. A., \& Osman, M. A. (2018). Effect of process variables on formulation, in-vitro characterisation and subcutaneous delivery of insulin PLGA nanoparticles: An optimisation study. Journal of Drug Delivery Science and Technology, 43, 160-171. doi:https://doi.org/10.1016/j.jddst.2017.10.004

196. Haggag, Y., Abdel-Wahab, Y., Ojo, O., Osman, M., El-Gizawy, S., El-Tanani, M., Faheem, A., \& McCarron, P. (2016). Preparation and in vivo evaluation of insulin-loaded biodegradable nanoparticles prepared from diblock copolymers of PLGA and PEG. International Journal of Pharmaceutics, 499(1), 236-246. doi:https://doi.org/10.1016/j.ijpharm.2015.12.063

197. Peng, Q., Zhang, Z. R., Gong, T., Chen, G. Q., \& Sun, X. (2012). A rapid-acting, long-acting insulin formulation based on a phospholipid complex loaded PHBHHx nanoparticles. Biomaterials, 33(5), 1583-8. doi:10.1016/j.biomaterials.2011.10.072

198. Chou, H. S., Larsson, M., Hsiao, M. H., Chen, Y. C., Roding, M., Nyden, M., \& Liu, D. M. (2016). Injectable insulin-lysozyme-loaded nanogels with enzymatically-controlled degradation and release for basal insulin treatment: In vitro characterization and in vivo observation. J Control Release, 224, 33-42. doi:10.1016/j.jconrel.2015.12.036

199. Gu, Z., Aimetti, A. A., Wang, Q., Dang, T. T., Zhang, Y., Veiseh, O., Cheng, H., Langer, R. S., \& Anderson, D. G. (2013). Injectable nano-network for glucosemediated insulin delivery. ACS Nano, 7(5), 4194-201. doi:10.1021/nn400630x

200. Xu, C., Lei, C., Huang, L., Zhang, J., Zhang, H., Song, H., Yu, M., Wu, Y., Chen, C., \& Yu, C. (2017). Glucose-Responsive Nanosystem Mimicking the Physiological Insulin Secretion via an Enzyme-Polymer Layer-by-Layer Coating Strategy. Chemistry of Materials, 29(18), 7725-7732. doi:10.1021/acs.chemmater.7b01804

201. Mo, R., Jiang, T., Di, J., Tai, W., \& Gu, Z. (2014). Emerging micro- and nanotechnology based synthetic approaches for insulin delivery. Chemical Society Reviews, 43(10), 3595-3629. doi:10.1039/C3CS60436E 
202. Guo, Q., Wu, Z., Zhang, X., Sun, L., \& Li, C. (2014). Phenylboronate-diol crosslinked glycopolymeric nanocarriers for insulin delivery at physiological $\mathrm{pH}$. Soft Matter, 10(6), 911-920. doi:10.1039/C3SM52485J

203. Wang, B., Ma, R., Liu, G., Li, Y., Liu, X., An, Y., \& Shi, L. (2009). GlucoseResponsive Micelles from Self-Assembly of Poly(ethylene glycol)-b-Poly(acrylic acid-co-acrylamidophenylboronic acid) and the Controlled Release of Insulin. Langmuir, 25(21), 12522-12528. doi:10.1021/la901776a

204. Wang, Y., Zhang, X., Han, Y., Cheng, C., \& Li, C. (2012). pH- and glucosesensitive glycopolymer nanoparticles based on phenylboronic acid for triggered release of insulin. Carbohydrate Polymers, 89(1), 124-131.

doi:https://doi.org/10.1016/j.carbpol.2012.02.060

205. Veiseh, O., Tang, B. C., Whitehead, K. A., Anderson, D. G., \& Langer, R. (2014). Managing diabetes with nanomedicine: challenges and opportunities. Nature Reviews Drug Discovery, 14, 45. doi:10.1038/nrd4477

206. Yu, W., Bien-Aime, S., Li, J., Zhang, L., McCormack, E. S., Goldberg, I. D., Narayan, P., \& Uhrich, K. E. (2015). Injectable microspheres for extended delivery of bioactive insulin and salicylic acid. Journal of Bioactive and Compatible Polymers, 30(3), 340-346. doi:10.1177/0883911515569919

207. Zhao, F., Wu, D., Yao, D., Guo, R., Wang, W., Dong, A., Kong, D., \& Zhang, J. (2017). An injectable particle-hydrogel hybrid system for glucose-regulatory insulin delivery. Acta Biomater, 64, 334-345. doi:10.1016/j.actbio.2017.09.044

208. Liu, J., Zhang, S. M., Chen, P. P., Cheng, L., Zhou, W., Tang, W. X., Chen, Z. W., \& Ke, C. M. (2007). Controlled release of insulin from PLGA nanoparticles embedded within PVA hydrogels. Journal of Materials Science: Materials in Medicine, 18(11), 2205-2210. doi:10.1007/s10856-007-3010-0

209. Peng, Q., Sun, X., Gong, T., Wu, C. Y., Zhang, T., Tan, J., \& Zhang, Z. R. (2013). Injectable and biodegradable thermosensitive hydrogels loaded with PHBHHx nanoparticles for the sustained and controlled release of insulin. Acta Biomater, 9(2), 5063-9. doi:10.1016/j.actbio.2012.09.034

210. Bohr, A., Water, J., Beck-Broichsitter, M., \& Yang, M. (2015). Nanoembedded Microparticles for Stabilization and Delivery of Drug-Loaded Nanoparticles. Curr Pharm Des, 21(40), 5829-44.

211. Lee, Y.-S., Johnson, P. J., Robbins, P. T., \& Bridson, R. H. (2013). Production of nanoparticles-in-microparticles by a double emulsion method: A comprehensive study. European Journal of Pharmaceutics and Biopharmaceutics, 83(2), 168173. doi:https://doi.org/10.1016/j.ejpb.2012.10.016

212. Sheikh Hasan, A., Sapin, A., Damgé, C., Leroy, P., Socha, M., \& Maincent, P. (2015). Reduction of the in vivo burst release of insulin-loaded microparticles. 
Journal of Drug Delivery Science and Technology, 30, 486-493.

doi:https://doi.org/10.1016/j.jddst.2015.06.020

213. Zaykov, A. N., Mayer, J. P., \& DiMarchi, R. D. (2016). Pursuit of a perfect insulin. Nature Reviews Drug Discovery, 15, 425. doi:10.1038/nrd.2015.36

214. Roberts, B. K., Wang, X., Rosendahl, M., \& Mantriprigada, S. The Extended Duration Single Dose Pharmacokinetics (PK) and Pharmacodynamics (PD) of AB101, a Potential Once Weekly Basal Subcutaneous (SC) Insulin, in Diabetic Miniature Swine. in DIABETES. 2016. AMER DIABETES ASSOC $1701 \mathrm{~N}$ BEAUREGARD ST, ALEXANDRIA, VA 22311-1717 USA.

215. Wronkowitz, N., Hartmann, T., Gorgens, S. W., Dietze-Schroeder, D., Indrakusuma, I., Choi, I. Y., Park, S. H., Lee, Y. M., Kwon, S. C., Kang, Y., Hompesch, M., \& Eckel, J. (2017). (LAPS) Insulin115: A novel ultra-long-acting basal insulin with a unique action profile. Diabetes Obes Metab, 19(12), 17221731. doi:10.1111/dom.13006

216. Hwang, S., Choi, I., Kim, J., Jung, S., Kim, D., Lee, Y., Kim, Y., Trautmann, M., Hompesch, M., \& Son, J. (2014). A Novel Very Long-Acting Insulin Analog (HM12470) with Potential for Once-Weekly Dosing, Has a Favorable PK, PD and Mitogenic Profile. Insulin, 100(100), 100.

217. Hwang, S., Kim, J., Kim, J., Choi, I., Hompesch, M., \& Kwon, S. Underlying Mechanisms for Long-Acting Properties of the Novel Weekly Insulin, LAPS Insulin 115 (HM12470).

218. Strohl, W. R. (2015). Fusion Proteins for Half-Life Extension of Biologics as a Strategy to Make Biobetters. BioDrugs, 29(4), 215-239. doi:10.1007/s40259-0150133-6

219. Jowett, J., Woods, C., \& Arnold, S., Therapeutic agents, compositions, and methods for glycemic control. 2015, Google Patents.

220. Diabetes News Journal. (2015, November 12). Type 2 diabetes study of onceweekly insulin treatment now enrolling patients. Retrieved from https://diabetesnewsjournal.com/2015/11/12/type-2-diabetes-study-weeklyinsulin-treatment-now-enrolling-patients/

221. PhaseBio. (2015, November 9). PhaseBio announces initiation of phase 2a multiple ascending dose study of once-weekly basal insulin PE0139 in type 2 diabetes. Retrieved from https://phasebio.com/phasebio-announces-initiation-ofphase-2a-multiple-ascending-dose-study-of-once-weekly-basal-insulin-pe0139-intype-2-diabetes/

222. Novo Nordisk. (2018, November 01). Pipeline. Retrieved from https://www.novonordisk.com/research-and-development/pipeline.html 


\section{VITA}

Kumar Kulldeep Niloy was born in Rangpur, Bangladesh in 1992. He graduated with Bachelor of Pharmacy degree in 2014 and Master of Pharmacy degree with a focus on Clinical Pharmacy and Pharmacology in 2016 from University of Dhaka in Bangladesh. In August 2017, Niloy joined in The University of Tennessee Health Science Center as a graduate student in Department of Pharmaceutical Sciences. He anticipates completion of the requirements for his Master of Science degree in Pharmaceutical Sciences with a focus on Pharmaceutics in May 2019. 